A R C HIWA，BIBLIOTEKI

I MUZEA KOŚCIELNE 111 (2019)

https://doi.org.10.31743/abmk.2019.111.15

MARCIN SANAK* - KRAKÓW

\title{
„SKARBIEC PRZEMOŻNY DROGICH PAMIĄTEK”. ZARYS DZIEJÓW \\ ARCHIWUM POLSKIEJ PROWINCJI DOMINIKANÓW W KRAKOWIE ${ }^{1}$
}

\begin{abstract}
Streszczenie
W średniowieczu bracia kaznodzieje przechowywali archiwalia w skrzyniach, a rękopisy po zmarłych zakonnikach w bibliotekach klasztornych. Sformułowanie ,archivum commune provinciae” (,wspólne archiwum prowincji”) po raz pierwszy pojawiło się w aktach kapituły generalnej dominikanów w Wenecji w 1592 r. Kolejne kapituły polecały braciom bezpieczne przechowywanie przywilejów, bulli i akt procesów, spisywanie źródeł do historii prowincji oraz tworzenie inwentarzy dóbr, których duplikaty miały trafiać do centralnego archiwum prowincji. Ostateczne prawne ustanowienie archiwów prowincji miało miejsce na kapitule generalnej w Rzymie w 1756 r. Archiwum prowincji polskiej w XVIII w. przechowywano w bibliotece konwentu krakowskiego pw. Św. Trójcy; w związku z planami beatyfikacji Męczenników Sandomierskich, generał zakonu polecił jego katalogowanie. W pierwszej połowie następnego stulecia mieściło się już w odrębnym pomieszczeniu, dzięki czemu przetrwało pożar klasztoru w $1850 \mathrm{r}$. W następnych dekadach archiwum ponownie znajdowało się w bibliotece; na przełomie XIX i XX w. opiekował się nim br. Kazimierz Jucewicz, a w drugiej dekadzie XX w. prac porządkowych podjął się o. Jacek Woroniecki OP. W 1926 r. ustanowiono urząd archiwariusza prowincji, który sprawowali kolejno ojcowie: Fabian Madura, Zygmunt Ogarek,
\end{abstract}

* Marcin Sanak - mgr historii; doktorant na Wydziale Historycznym Uniwersytetu Jagiellońskiego w Krakowie; pracownik Archiwum Polskiej Prowincji Dominikanów w Krakowie;

e-mail:marcinsanak@wp.pl

https://orcid.org/0000-0003-0167-1968

${ }^{1}$ Pragnę podziękować archiwiście Polskiej Prowincji Dominikanów - dr. Ireneuszowi Wysokińskiemu OP, za udostępnienie źródeł archiwalnych i sprawozdań z okresu pełnienia przez niego urzędu, życzliwe uwagi oraz słowa zachęty do publikacji niniejszego tekstu. Słowa wdzięczności za cenne wskazówki kieruję również do dr Elżbiety Wiater i mgr Małgorzaty Habudy oraz dr. Wiktora Szymborskiego, mgr. Wiesława Filipczyka, mgr. Adriana Cieślika i mgr. Pawła Bieleckiego. 
Andrzej Gmurowski, Robert Świętochowski i Efrem Gliński. W 1937 r. archiwum zostało przeniesione do odrębnego magazynu. Na powojenne zorganizowanie Archiwum Polskiej Prowincji Dominikanów w obecnym kształcie duży wpływ miało ulokowanie w Krakowie licznych materiałów z likwidowanych klasztorów na Kresach południowo-wschodnich. Urząd archiwisty prowincji od 1946 r. pełnili ojcowie: Robert Świętochowski, Paweł Kielar, Zygmunt Bruno Mazur i Jan Andrzej Spież. Od 2009 r. archiwum kieruje o. Ireneusz Wysokiński OP.

Słowa kluczowe: Archiwum Polskiej Prowincji Dominikanów; archiwum; dominikanie; Polska Prowincja Dominikanów; klasztor Dominikanów w Krakowie; Kraków

Spośród wielu archiwów zakonnych w Polsce, do najważniejszych należy zaliczyć Archiwum Polskiej Prowincji Dominikanów w Krakowie. Instytucja przechowuje materiały wytworzone w wyniku działalności braci, a w mniejszym stopniu także sióstr, z kilku prowincji Zakonu Kaznodziejskiego: polskiej (12211864 i od 1927), ruskiej (1612-1839), litewskiej (1644-1842) i galicyjskiej (ok. 1772-1927), a także kongregacji obserwanckiej św. Ludwika Bertranda na terenie Rzeczpospolitej (1671-1795) i kongregacji bł. Czesława na Śląsku (1754-1808). Na bogaty zasób archiwum składają się m.in. setki dyplomów pergaminowych sięgających XIII w., wielkoformatowe księgi liturgiczne ze zdobnymi inicjałami, średniowieczne i nowożytne rękopisy dzieł zakonników, akta klasztorów, bractw różańcowych i kapituł prowincjalnych, jak również spuścizny wybitnych kaznodziejów, duszpasterzy i uczonych. Archiwalia te stanowią bezcenne źródła do badań nad religijnym, naukowym, kulturalnym oraz artystycznym wkładem Zakonu Kaznodziejskiego w życie ziem dawnej Rzeczpospolitej. Zasób dominikańskiego archiwum nie jest jednak zamknięty: instytucja wciąż przejmuje materiały, powstałe w wyniku działalności kurii prowincjalnej, klasztorów i zakonników. Współczesne zasady jej funkcjonowania reguluje przede wszystkim Księga konstytucji i zarzadzeń Braci Zakonu Kaznodziejów oraz statut prowincji. Pierwszy $\mathrm{z}$ dokumentów wskazuje, że w archiwum pod opieką archiwisty prowincji powinny być gromadzone:

$1^{\circ}$ Dokumenty przechowywane u prowincjała lub oficjalistów prowincji, które nie są już potrzebne dla bieżącego zarządu.

$2^{\circ}$ Dokumenty zniesionych klasztorów.

$3^{\circ}$ Nieopublikowane pisma, listy lub inne dokumenty zmarlych braci, a nawet ludzi postronnych, które zdają się posiadać jakieś znaczenie dla historii prowincji ${ }^{2}$.

${ }^{2}$ Księga konstytucji i zarządzeń Braci Zakonu Kaznodziejów, Poznań 2003, s. 149 (zarządzenie nr 381). 
Konstytucje zobowiązują ponadto zakonników do przesyłania do archiwum jednego egzemplarza pracy, która ukazała się drukiem ${ }^{3}$.

Choć źródła do historii dominikanów na ziemiach polskich cieszą się niesłabnącym zainteresowaniem ze strony badaczy, samo archiwum prowincji - jak również powiązane z nim archiwum konwentu krakowskiego - nie doczekało się dotąd obszerniejszego szkicu swych złożonych dziejów. Próby odtworzenia oraz charakterystyki zasobu archiwum w średniowieczu i XVI stuleciu podjął się jeszcze w okresie międzywojennym Jan Fijałek ${ }^{4}$. Później dopiero w 1971 r. opublikowany został krótki artykuł Roberta Świętochowskiego, w którym zakonnik podał podstawowe informacje o historii archiwum w kontekście rozwoju ,archiwistyki dominikańskiej”, a także pobieżnie omówił zasób pod kątem określonych grup materiałów ${ }^{5}$. Pięć lat później część tych informacji dominikanin powtórzył na marginesie rozważań o przeszłości biblioteki klasztoru krakowskiego ${ }^{6}$. Następnie ówczesny zasób archiwum opisali pokrótce: Romuald Szpor (w artykule popularnonaukowym) ${ }^{7}$, a także autorzy Katalogu zabytków sztuki w Polsce ${ }^{8}$. W kolejnych dekadach poszczególni archiwiści prowincji redagowali krótkie noty na temat zasobu i działalności instytucji, które zamieszczano w informatorach wydawanych przez Naczelną Dyrekcję Archiwów Państwowych lub Bibliotekę Narodową w Warszawie. Jak dotąd najszerzej dzieje i zasób archiwum w jednej z takich publikacji omówił obecny archiwista prowincji, Ireneusz Wysokiński ${ }^{9}$. Zdawkowe informacje o kształtowaniu zasobu znalazły się także w nielicznych, wydanych drukiem inwentarzach poszczególnych zespołów ${ }^{10}$. Jak dotąd stosunkowo nie-

${ }^{3}$ Tamże, s. 77 (zarządzenie nr 140).

${ }^{4}$ J. Fijałek, Wstęp, w: Zbiór formut Zakonu Dominikańskiego Prowincji Polskiej 1338-1411 = (Dictamina litterarum O. P. Provinciae Polonae), przedłożył do druku J. Woroniecki, poprzedził wstępem i wydał J. Fijałek, Kraków 1938 (Archiwum Komisji Historycznej, t. 12, cz. 2), s. 228 i n.

${ }^{5}$ R. Świętochowski, Źródta do dziejów nowożytnych Zakonu Kaznodziejskiego w Polsce, „Sprawozdania Towarzystwa Naukowego Katolickiego Uniwersytetu Lubelskiego”, (1970) nr 19, s. 84-91. Autor - wbrew tytułowi - omawia cały zasób archiwum, w tym źródła do historii polskich dominikanów w średniowieczu i okresie najnowszym.

${ }^{6}$ Tenże, Biblioteka oo. Dominikanów w Krakowie, „Archiwa, Biblioteki i Muzea Kościelne”, 33 (1976) s. 300-301.

${ }^{7}$ R. Szpor, Biblioteka i archiwum świadkami życia wspólnoty dominikańskiej, „Życie i Myśl”, (1977) nr 10, s. 45-56.

${ }^{8}$ Katalog zabytków sztuki w Polsce, t. 4: Miasto Kraków, cz. 3: Kościoły i klasztory Śródmieścia, 2. [1] Tekst, red. A. Bochnak, J. Samek, Warszawa 1978, s. 189-190 (rękopisy biblioteczne i księgi liturgiczne - znajdujące się wówczas w bibliotece klasztornej, a obecnie w archiwum prowincji - omówiono na s. 191-201; bibliografię na temat archiwum i biblioteki podano na s. 223).

${ }^{9}$ I. Wysokiński, Kraków - Archiwum Polskiej Prowincji Dominikanów, w: Rękopisy w zbiorach kościelnych, oprac. T. Makowski, Warszawa 2014, s. 112-115.

${ }^{10} \mathrm{~K}$. Mrowiec, Katalog muzykaliów gidelskich. Rękopisy muzyczne kapeli klasztoru gidelskiego przechowywane w Archiwum Prowincji Polskiej OO. Dominikanów w Krakowie, Kraków 1986, s. 11-12; A. Litewka, Inwentarz zespołu akt Gidle. Klasztor ojców dominikanów z lat (1479) 16151998, „Archiwa, Biblioteki i Muzea Kościelne”, 99 (2013) s. 117-119. 
wiele uwagi poświęcono także bibliotece klasztoru krakowskiego ${ }^{11}$, z którą ściśle wiążą się losy archiwum, jak również dominikańskiemu prawodawstwu archiwalnemu ${ }^{12}$. Niniejszy artykuł stawia sobie za cel całościowe, a zarazem syntetyczne zarysowanie genezy i dziejów Archiwum Polskiej Prowincji Dominikanów, które nie wyczerpuje jednak tematu.

\section{Geneza i początki centralnego archiwum polskich dominikanów}

Pierwsi bracia kaznodzieje przybyli do Krakowa w 1221 r., a cztery lata później powstała zakonna prowincja polska. Przez setki lat - aż do okresu zaborów funkcje najważniejszego klasztoru dominikanów, siedziby kolejnych prowincjałów oraz studium generalnego spełniał najstarszy konwent krakowski pw. Św. Trójcy. Jego archiwum stanowiło podstawę późniejszego archiwum głównego prowincji. W pierwszych wiekach działalności zakonu nie można jednak mówić o istnieniu archiwów klasztornych we współczesnym znaczeniu tego słowa - jako osobnego pomieszczenia lub instytucji. W średniowieczu najpopularniejszą formą przechowywania przez przełożonych przywilejów, bulli czy korespondencji stało się składanie ich w skrzyniach; nie inaczej musiało być także w konwentach braci kaznodziejów. Dominikanie zachowywali ponadto odręczne dzieła współbraci, jednak w sposób wybiórczy - w zależności od bieżących potrzeb związanych ze sprawami prawno-kanonicznymi, zarządzaniem majątkami czy działalnością na

${ }^{11} \mathrm{Na}$ temat historii biblioteki krakowskiego klasztoru dominikanów i jej zbiorów zob. m.in.: J.A. Kosiński, Doskonały książkołap. Wizyta Tadeusza Czackiego w bibliotece dominikanów krakowskich, „Roczniki Biblioteczne”, (1960) nr 1/2, s. 223-229; K. Zawadzka, Ze źródet i stanu badań dotyczacych dawnych klasztornych bibliotek dominikanów w polskich prowincjach, „Nasza Przeszłość”, 39 (1973) s. 215, przypis 20 (bibliografia); Świętochowski, Biblioteka oo. Dominikanów, s. 299-311; M. Zdanek, Szkoły i studia dominikanów krakowskich w średniowieczu, Warszawa 2005, s. 9, 75-81, 151-162; I. Pietrzkiewicz, Biblioteki mendykantów krakowskich w okresie średniowiecza - stan i perspektywy badań, w: Mendykanci w średniowiecznym Krakowie, red. K. Ożóg, T. Gałuszka, A. Zajchowska, Kraków 2008 (Studia i Źródła Dominikańskiego Instytutu Historycznego w Krakowie, t. 4), s. 139 i n.; T. Gałuszka, W przededniu powstania Studium Generale. Nowe badania nad czternastowiecznym zachowanym księgozbiorem dominikanów krakowskich, „Przegląd Tomistyczny”, 16 (2010) s. 25-42; D. Kuźmina, M. Habuda, Biblioteka oo. Dominikanów w Krakowie, w: Kraków-Lwów. Książki, czasopisma, biblioteki XIX i XX wieku, t. 10, red. H. Kosętka, G. Wrona, G. Nieć, Kraków 2011, s. 389-399; M. Habuda, K. Płaszczyńska-Herman, J. Kaczmarek, Biblioteka Kolegium Filozoficzno-Teologicznego oo. Dominikanów w Krakowie, „Tytuł Ujednolicony. Wokół katalogu centralnego NUKAT", (2013) nr 11, s. 3-7. Zob. także: Archiwum Polskiej Prowincji Dominikanów w Krakowie (dalej: APPD), bez sygn., K. Zawadzka, Problem rekonstrukcji biblioteki klasztoru Dominikanów w Krakowie.

${ }^{12}$ Dominikańskie prawodawstwo - w tym archiwalne - już w XVII w. zestawił i zwięźle omówił V.M. Fontana, Constitutiones, declarationes et ordinationes capitulorum generalium S. Ordinis Praedic. ab anno 1220 usque ad 1651 emanatae, Romae 1655, kol. 47-48. W XIX w. jego dzieło doczekało się uzupełnień i aktualizacji, zob.: V. Fontana, C. Lo-Cicero, Constitutiones, declarationes et ordinationes capitulorum generalium Sacri Ordinis Fratrum Praedicatorum ab anno 1220 ad 1650 emanatae [...] usque ad annum 1862 continuatae [...], cz. 1, Romae 1862, s. 35-36. 
polu teologii, filozofii i liturgii. Po śmierci zakonników trafiały do bibliotek klasztornych, służąc kolejnym pokoleniom kaznodziejów i uczonych; stąd też współcześnie określane są jako tzw. rękopisy biblioteczne ${ }^{13}$.

Najstarszy zachowany do dzisiaj transumpt dokumentów klasztoru krakowskiego sporządzony został w $1531 \mathrm{r}$. przez tamtejszego przeora Hieronima de Brzezek; on także podjął rok wcześniej starania o sporządzenie uzupełnianego później kopiariusza akt konwentu ${ }^{14}$. Jak twierdzi Robert Świętochowski, urząd archiwisty - prawdopodobnie po raz pierwszy u dominikanów na ziemiach polskich - został ustanowiony w $1583 \mathrm{r}$. w Krakowie. Jego zdaniem poszukiwania archiwalne związane z planowaną kanonizacją św. Jacka miały także doprowadzić do oddzielenia - na żądanie tamtejszego przeora Feliksa z Sieradza (z Wierzbna) archiwum od biblioteki ${ }^{15}$. Kapituła generalna dominikanów w Wenecji w 1592 r. potwierdzała zarządzenie mówiące, że oryginały lub kopie procesów braci powinny być złożone we „wspólnym archiwum prowincji” (,archivum commune provinciae" ${ }^{16}$. Tym samym po raz pierwszy w prawodawstwie dominikańskim pojawiło się sformułowanie odnoszące się do idei centralnego archiwum danej prowincji. Sama nazwa „archivum provinciae” będzie pojawiać się w aktach kapituł generalnych w Tuluzie (1628) oraz Rzymie (1629 i 1656), jednak ostatecznie zdefiniowana zostanie dopiero w połowie XVIII stulecia.

Tendencje separatystyczne klasztorów ruskich na przełomie XVI i XVII w., które doprowadziły do ich procesu z prowincją polską, zapoczątkowały badania historyczne w oparciu o zgromadzone w Krakowie materiały archiwalne ${ }^{17}$. W tym samym okresie kapituła generalna zakonu, obradująca w 1600 r. w Neapolu, zobowiązała prowincjałów i wikariuszy kongregacji do wskazania jednego lub kilku braci, których zadaniem miało być spisywanie źródeł do historii prowincji lub kongregacji w każdym z klasztorów. Zakonnicy mieli zwrócić uwagę na dokumenty dotyczące m.in. fundacji konwentów, rozwoju kultu różańcowego, wybitnych uczonych, kaznodziejów, hierarchów oraz zmarłych w opinii świętości braci ${ }^{18}$. Polscy dominikanie szybko zastosowali się do postanowień

${ }^{13}$ Wysokiński, Kraków - Archiwum, s. 112.

${ }^{14}$ APPD, sygn. $\mathrm{Kr}$ 23, Liber continens in se tenores, sive transsumpta omnium litterarum, privilegiorumque apostolicarum necnon Regalium aliorumque tam spiritualium, quam secularium, necnon Obligationum et Proventuum Conventus Cracoviensis Sanctissimae Trinitatis ordinis predicatorum extractus ex litteris originalibus prout in forma habentur de verbo ad verbum cura non mediocri R. patre fratre Hieronimo de Brzezek sacre theologie lectore ac Conventus iam dicti priore necnon totius provincie Polonie Vicario generali procurante M. D. XXXI. Salutis nostre Anno; APPD, sygn. $\mathrm{Kr}$ 1, Liber antiquitatum et intercisarum, bullar[um] sum. Pontif. ac privilegiorum regalium et censuum inscriptionu[m] atq[ue] Obligationu[m] Missarum. Con[ven]tus Ord[in]is Praed[icatoru]m SS-mae Trini[ta]tis.

${ }^{15}$ Świętochowski, Biblioteka oo. Dominikanów, s. 300-301; APPD, bez sygn., [R. Świętochowski], Archiwum OO. Dominikanów w Krakowie [mps, wersja nr 1], k. 1.

${ }^{16}$ Acta Capitulorum Generalium Ordinis Praedicatorum, t. 5: ab anno 1558 usque ad annum 1600, Romae 1901 (Monumenta Ordinis Fratrum Praedicatorum Historica, t. 10), s. 312.

${ }^{17}$ APPD, bez sygn., [R. Świętochowski], Archiwum OO. Dominikanów w Krakowie [mps, wersja nr 1], k. 1-2.

${ }^{18}$ Acta Capitulorum Generalium Ordinis Praedicatorum, t. 5, s. 388-389. 
kapituły, a do klasztoru krakowskiego w kolejnych latach trafiło wiele kopiariuszy. W 1606 r. historiograf polskich dominikanów - Abraham Bzowski - wydał w Wenecji dzieło poświęcone życiu św. Jacka Odrowąża. Autor Propago Divi Hyacinthi w znacznym stopniu korzystał ze zbiorów krakowskiego „Archiv[um] Prouincie [!]”, a dzięki powoływaniu się na konkretne dokumenty rzuca światło na jego ówczesny zasób ${ }^{19}$.

Kapituła generalna w Rzymie w 1608 r. zarządziła, by każdy klasztor posiadał dobrze zabezpieczone szafy lub skrzynie (,armaria sive capsi”), w których przechowywane będą takie dokumenty, jak kontrakty i księgi profesji braci, listy oraz przywileje - włącznie $\mathrm{z}$ ich inwentarzem. $\mathrm{W}$ archiwum konwentu powinien znaleźć się także inwentarz dóbr ruchomych i nieruchomych kościoła i klasztoru, którego drugi egzemplarz miał trafić do archiwum głównego konwentu prowincji lub kontraty (,archivio primarii provinciae vel nationis conventus") ${ }^{20}$. W $1611 \mathrm{r}$. zarządzenia te potwierdzono na kapitule generalnej w Paryżu ${ }^{21}$, ale już dwa lata wcześniej odwoływali się do nich bracia z prowincji polskiej w czasie kapituły prowincjalnej w Przemyślu ${ }^{22}$. Kapituła generalna w Bolonii w 1615 r. polecała prowincjałom wieczyste przechowywanie przywilejów wydanych przez Stolicę Apostolską oraz zarządzeń generała zakonu; miały być składane w jednym lub dwóch najważniejszych klasztorach prowincji ${ }^{23}$. Z kolei kapituła generalna w Tuluzie w 1628 r. nakazała, by w archiwum prowincji przechowywano akta procesów braci, powstałe $\mathrm{w}$ wyniku działalności komisarzy i wizytatorów ${ }^{24}$. W 1629 r. kolejna kapituła obradująca w Rzymie potwierdziła wcześniejsze przepisy zobowiązujące prowincjałów i wikariuszy kongregacji do dopilnowania, by do archiwów prowincji trafiały oryginalne księgi inwentarzowe dóbr ruchomych i nieruchomych klasztorów ${ }^{25}$. Rok później do wspomnianych zapisów odwoływali się polscy dominikanie na kapitule prowincjalnej w Sandomierzu ${ }^{26}$. W $1631 \mathrm{r}$. bracia zgromadzeni na kapitule w Warszawie postanowili z kolei, by do archiwum prowincji w Krakowie trafiły rękopisy akt wszystkich kapituł prowincjalnych ${ }^{27}$. W połowie XVII w. dominikanin Arnolf Prężyna (Presinius) sporządził dwie księgi, w których zawarł opisy krakowskiego kościoła i klasztoru Św. Trójcy, w tym

${ }^{19}$ A. Bzovii, Propago D[ivi] Hyacinthi thaumaturgi Poloni, seu De rebus praeclare gestis in Prouincia poloniae Ordinis Praedicatorum commentarius, Venetiis 1606. Zasób ówczesnego archiwum prowincji w oparciu o dzieło Bzowskiego omawia J. Fijałek, Wstęp, s. 228 i n.

${ }^{20}$ Acta Capitulorum Generalium Ordinis Praedicatorum, t. 6: ab anno 1601 usque ad annum 1628, Romae 1902 (Monumenta Ordinis Fratrum Praedicatorum Historica, t. 11), s. 99.

${ }^{21}$ Tamże, s. 133.

${ }^{22}$ APPD, sygn. S 44/8a, Acta Capitulorum Provinciae Poloniae Ordinis Praedicatorum, t. 2 : a. 1603-1700, oprac. R.F. Madura, k. 92-93.

${ }^{23}$ Acta Capitulorum Generalium Ordinis Praedicatorum, t. 6, s. 243.

${ }^{24}$ Tamże, s. 371.

${ }^{25}$ Acta Capitulorum Generalium Ordinis Praedicatorum, t. 7: ab anno 1629 usque ad annum 1656, Romae 1902 (Monumenta Ordinis Fratrum Praedicatorum Historica, t. 12), s. 9.

${ }^{26}$ APPD, sygn. S 44/8b, Acta Capitulorum Provinciae Poloniae Ordinis Praedicatorum, t. 2: a. 1603-1700, oprac. R.F. Madura, k. 436.

${ }^{27}$ Tamże, k. 473. 
jego inwentarzy i ksiąg chórowych ${ }^{28}$. Bazując na jednym z kodeksów Prężyny, w 1700 r. analogiczne dzieło spisał Anzelm Dorecki ${ }^{29}$. Cenny, lecz stosunkowo pobieżny regestr archiwum został sporządzony także w 1715 roku. Wynika z niego, że dokumenty pergaminowe, księgi i fascykuły przechowywano w skrzyniach („In Arca”, „In Scatula Mediocri”, „In Scatula Maiori”); niemal wszystkie posiadały sygnaturę - literową lub liczbową ${ }^{30}$.

Kapituła generalna w Bolonii w 1748 r. ponowiła zarządzenia kapituły z 1611 r., dotyczące gromadzenia w archiwach klasztornych inwentarzy dóbr ruchomych i nieruchomych oraz przekazywania ich duplikatów do archiwum głównego klasztoru prowincji ${ }^{31}$. W połowie XVIII stulecia w prowincjach Zakonu Kaznodziejskiego na ziemiach polskich ponownie ożywiły się badania historyczne $^{32}$. Kapituła polskich dominikanów w Łucku w 1749 r. poleciła o. Felicjanowi Nowowiejskiemu napisanie dziejów prowincji, które pod nazwą Phaenix decoris et ornamenti Provinciae Poloniae S. Ordinis Praedicatorum zostały wydane w Poznaniu w $1752 \mathrm{r} .{ }^{33}$ Starania stworzenia centralnych archiwów w prowincjach dominikańskich ostatecznie znalazły swe zwieńczenie na kapitule generalnej w Rzymie w 1756 r. Zgromadzeni na niej bracia polecili, by na kolejnej kapitule

${ }^{28}$ APPD, sygn. Kr 3, Protocollum Priuilegiorum, Fundationum, Dotationum, Inscriptionum, Censuum, Prouentuum, Villarum, Domorum, Obligationum, Literarum, Regalium, Commisionum... Concordiarum, Inuentarium, Clenodiorum, Apparamentorum, Librorum Choralium, Ecclesiae, et Conuentus SS. Trinitatis Fratrum Praedicatorum fideliter descriptum, et consignatum Per Fr. Arnolfum Presinium Magistrum. 1648; APPD, sygn. Kr 5, Descriptio fundationis Ecclesiae S[anctissi]mae Trini[ta]tis et Mona[ste]rii Sacri Ordinis Fr[atr]um Praed[icatoru]m Villarum Prouentuu[m], \& Censuum Con[ven]tus Cracouiensis. Aliorumq[ue] Bonorum Immobilium \&c. Per Fr[atr] em Arnolphum S: T: M[a]g[ist]rum. Descriptio Obligationum Missarum Anniuersariorum et Orationu[m]. Ex Antiquis Scriptu[ri]s. Adnotationib[us]q[ue]. in Annalibus, ex Calendis Pargameneis. Copiis Intercisarum et Recognitionum et ex Authenticis Actis Consiliorum Con[ven]tus Cracoui[ensi]s. Informatio de structura Altaris Maioris. De Organis. Descriptio Gradualium, Antiphonariorum, Psalteriorum, Processionalium, Aliorumq[ue]. Librorum choralium. Inwentarz Zakristyi.

${ }^{29}$ APPD, sygn. Kr 4, Protocollon Privilegiorum, Fundationum, Donationum, Inscriptionum, Censuum, Prouentuum, Villarum, Domorum, Obligationum, Literarum Regalium, Commisionum, Decretorum, Transactionum, Concordiarum, Inventariorum, ex Antiquiori Protocollo per olim R. A. P. M. F. Arnolphum Presinium in Anno 1648 - mo Conscripto postea sub Prioratu A - m R - di et Eximii Patris S. Th. Magistri P. Casimiri Napolski in secundissimo quia secundo ipsius Triennio, de Verbum relictis adhuc aliquibus descriptionibus, utpote in aliud Volumen Seorsum per modum Continuationis Una cum nonnullis accessoriis Bonorum, Fundationum Nouarum, Obligationum, Ornamentorum Ecclesiae reducandis, et inscribendis per P. F. Anselmum Dorecki Agentem protunc Causalem Conventus adiuvante Clerico fideliter Transcriptum et Consignatum Anno a Descriptione Nativitatis Christi Domini M. DCC.

${ }^{30}$ APPD, sygn. $\mathrm{Kr}$ 6, Księga zawierająca dokumenty i materiały do historii kościoła i klasztoru OO. Dominikanów krakowskich od 1219-1749 r., s. 471-494.

${ }^{31}$ Acta Capitulorum Generalium Ordinis Praedicatorum, t. 9: ab anno 1725 usque ad annum 1844, Romae 1904 (Monumenta Ordinis Fratrum Praedicatorum Historica, t. 14), s. 141.

${ }^{32}$ Zob.: S. Brzozecki, Historiografia dominikańska w czasach nowożytnych (XVII-XIX w.), „Kościół w Polsce. Dzieje i kultura”, 6 (2007) s. 19-20.

${ }^{33}$ R. Świętochowski, Nowowiejski Felicjan, w: Polski Słownik Biograficzny (dalej: PSB), t. 23, red. E. Rostworowski, Wrocław 1978, s. 401. 
w każdej prowincji wskazano klasztor, w którym swą siedzibę znajdzie odpowiednio przechowywane i zabezpieczone archiwum prowincji ${ }^{34}$. W przypadku prowincji polskiej zarządzenie to po raz kolejny podkreślało znaczenie archiwum krakowskiego, ale już w sąsiedniej prowincji ruskiej wiązało się ze zmianami, gdyż - zapewne na podstawie zarządzeń z Bolonii z 1615 r. - główne archiwa urządzono nie w jednym, lecz w dwóch klasztorach: we Lwowie i Podkamieniu ${ }^{35}$.

Dominikanie obradujący w 1756 r. w Wiecznym Mieście poświęcili swą uwagę także samemu archiwum konwentu krakowskiego. Polecili bowiem generałowi zakonu wskazanie odpowiednich mężów („viros idoneus”) do poszukiwania w nim materiałów dotyczących Męczenników Sandomierskich, w związku ze staraniami o ich beatyfikację. Bracia kapitulariusze uargumentowali tę decyzję sławą wspomnianego archiwum, mającego zawierać wiele pamiątek odnoszących się do historii nie tylko prowincji polskiej, ale i całego zakonu ${ }^{36}$. Zatwierdzając akta kapituły prowincjalnej w Łucku w 1756 r., generał dominikanów Juan Tomás de Boxadors wyznaczył do przeprowadzenia kwerendy późniejszego przeora krakowskiego (1757-1760, 1766-1768) Michała Barwińskiego, który miał spisać pamiątki i dokumenty odnoszące się do życia i kultu Sadoka i 48 towarzyszy, a następnie przesłać wykaz do Rzymu ${ }^{37}$. Niedługo później generał zakonu w liście do M. Barwińskiego z 21 maja 1757 r. wyłożył mu sposób opisu źródeł. Luźne dokumenty - począwszy od roku 1300 - miały zostać ponumerowane, by później móc łatwo je odnaleźć, a ich spis powinien podawać dokładne daty sporządzenia. W przypadku ksiąg należało odnotować autora, czas powstania, rodzaj materiału i format ${ }^{38}$.

Owocem prac porządkowych są zapewne krótkie sumariusze archiwów: prowincji polskiej, kopiariuszy klasztorów i konwentu krakowskiego z 1766 r. Ponieważ są ostatnimi zachowanymi inwentarzami z okresu staropolskiego, warto przyjrzeć się im bliżej. Powstały w roku wyboru M. Barwińskiego po raz drugi na urząd przeora krakowskiego; autorem ostatniego ze spisów był Ludwik Kochmański, który prawdopodobnie sporządził także dwa pierwsze. Sumariusze wskazują na rozdział archiwów pod kątem proweniencji akt (oryginały oddzielono od kopii przysyłanych z klasztorów), częściowo informują także o miejscu ich przechowywania. Opisy dokumentów, choć w większości przypadków zawierają sygnatury, wbrew poleceniom Boxadorsa są jednak bardzo lakoniczne. Pierwszy spis („Archivum Provinciae Ordinis Authentica Sub numero \& Alphabeto A. D. 1766 Revisum") wymienia 142 pozycje oznaczone zarówno numerami, jak i literami alfabetu (od „A” do „Zzzzzz”). Autor zawarł także informację o innych dokumentach

${ }^{34}$ Acta Capitulorum Generalium Ordinis Praedicatorum, t. 9, s. 252-253.

${ }^{35}$ APPD, sygn. S 44/11b, Acta Capitulorum Provinciae Russiae [Ordinis Praedicatorum], t. 5: ab a. 1598-1772, oprac. R.F. Madura, k. 787.

${ }^{36}$ Acta Capitulorum Generalium Ordinis Praedicatorum, t. 9, s. 257.

${ }^{37}$ APPD, sygn. S 44/9a, Acta Capitulorum Provinciae Poloniae [Ordinis Praedicatorum], t. 3: a. 1701-1798, oprac. R.F. Madura, k. 664.

${ }^{38}$ APPD, sygn. S 44/9c, Acta Capitulorum Provinciae Poloniae [Ordinis Praedicatorum], t. 3 : a. 1701-1798, oprac. R.F. Madura. Supplementum ex registris actorum regiminis rev.morum magistrorum generalium et procuratorum generalium O.P. (a. 1700-1800), k. 481-482. 
bez sygnatury oraz wymienił dwa z nich, znajdujące się w jednym z fascykułów ${ }^{39}$. Na odwrocie drugiej z kart tworzących spis znalazł się sumariusz ,archiwum kopiariuszy klasztorów”, przechowywanego w bibliotece konwentu („Archivum Conventuum Copiatim In Bibliotheca Conventus Cracoviensis observatum"). Obejmuje on 24 pozycje - w większości kopiariusze powstające od początków XVII w. - również oznaczone numerami i literami (od „A” do „Z”). Na końcu spisu autor podał informacje, że inne akta dotyczące urzędu prowincjalskiego, ujęte w fascykuły, przechowywane są w bibliotece razem $\mathrm{z}$ archiwum konwentu ${ }^{40}$. Ostatni sumariusz - wspomnianego archiwum klasztoru krakowskiego (,Archivum Domus Conventui SS. Trinitatis Conscriptum et Regestratum Anno Domini 1766") - w pierwszej kolejności wymienia dokumenty pergaminowe z sygnaturami liczbowymi (29 pozycji). Kochmański podał następnie inne akta, w tym m.in. brewe, listy, intercyzy i kontrakty, oznaczone literami (od „A” do „ZZ”- 48 pozycji). Wspomniał ponadto, że sygnatur nie posiadały inne dokumenty znalezione w drewnianej skrzyni ufundowanej przez Abrahama Bzowskiego dla dwóch studentów konwentu krakowskiego. Wszystkie archiwalia przechowywano w dużej skrzyni, oznaczonej literą „D” - zapewne od słowa „Documenta”41. Spis podaje dalej wykaz przywilejów, oznaczonych literami i liczbami (od „A” do „Z”- 24 pozycje) oraz siedmiu innych dokumentów, zgromadzonych w jednym fascykule.

Dzięki wszystkim wymienionym sumariuszom wiadomo, że archiwum konwentu, kopiariusze oraz część lub całość archiwum prowincji przechowywano w bibliotece klasztornej, częściowo lub w całości w skrzyniach, o których obecności milczą schematyczne opisy książnicy autorstwa Michała Siejkowskiego i Felicjana Nowowiejskiego ${ }^{42}$. W okresie staropolskim $w$ bibliotece $\mathrm{w}$ dalszym ciągu składano rękopisy biblioteczne; w 1820 r. znajdowało się tam 86 zapisanych odręcznie ksiąg in folio ${ }^{43}$. Gdy zbiory biblioteki spłoną trzy dekady później, krakowski dziennik „Czas” przytoczy opinię, że była ,jedną jak powiadali z najbogatszych w Europie

${ }^{39}$ APPD, sygn. Pp 3a/3, Archivum Provinciae Ordinis Authentica Sub numero \& Alphabeto A. D. 1766 Revisum. Archivum Conventuum Copiatim In Bibliotheca Conventus Cracoviensis observatum. Archivum Domus Conventui SS. Trinitatis Conscriptum et Regestratum Anno Domini 1766, kk. nlb.

${ }^{40}$ Tamże, k. nlb.

${ }^{41}$ APPD, sygn. Pp 3a/4, Archivum Domus Conventui SS. Trinitatis Conscriptum et Regestratum Anno Domini 1766, kk. nlb.

${ }^{42}$ M. Sieykowski, Światnica Pańska to iest Kościot Boga w Troycy SS. iedynego z klasztorem WW. OO. Dominikanow w Krakowie, znacznemi świętych Pańskich relikwiami, kaplicami, ottarzami, obrazami [...] przyozdobiona, wielkich $w$ cnotę [...] licznych mężow maiaca, Kraków 1743, s. 28; F. Nowowieyski, Phaenix decoris et ornamenti Provinciae Poloniae S. Ordinis Praedicatorum D. Hyacinthus Odrovansius redidivus..., Posnaniae 1752, s. 207.

${ }^{43}$ APPD, sygn. Kr 41, Inwentarz Kościoła Zakonnego i Klasztoru Xięży Dominikanów w Gminie I-szej przy ulicy Szeroka zwanej w Wolnym Mieście Krakowie sytuowanego na mocy tak Rozporządzenia Wydziału Spraw Wewnętrznych w Senacie Rządzącym dnia 20 Mca Paźdr. Roku 1820, jako też Odezwy Konsystorza Jeneralnego Krakowskiego pod dniem. Mca. Roku tegoż 182. Nr uczynionych stosownie do Instrukcji w tey mierze wydaney przez Delegowanych Kommisarzy Cywilno Duchownych sporządzony. Opis czyli Inwentarz Kościoła S. Idziego, k. nlb. 
w rzadkie manuskrypta"44. Jednak i wcześniej zgromadzone w bibliotece rękopisy padały ofiarą klęsk i wojen; przykładowo w czasie insurekcji kościuszkowskiej wiele papierowych dokumentów miało zostać przekazanych przez zakonników na tutki do sporządzania naboi ${ }^{45}$.

Według R. Świętochowskiego w XVIII w. doszło do częściowej centralizacji archiwów klasztornych, w wyniku której w Krakowie zgromadzono szczątkowe akta staropolskie niektórych konwentów ${ }^{46}$. Trzeci rozbiór Rzeczpospolitej (1795) sprawił, że miasto znalazło się na terenie zaboru austriackiego, w którym już wcześniej wyodrębniły się dominikańskie prowincje: Galicji Zachodniej i Galicji Wschodniej (następnie połączone w jedną prowincję galicyjską, która jako jedyna z prowincji na ziemiach polskich przetrwała do czasu odzyskania niepodległości w 1918 r.). Kraków początkowo przynależał do prowincji Galicji Zachodniej, od $1811 \mathrm{r}$. ponownie do prowincji polskiej, a od 1865 r. do prowincji galicyjskiej. W XIX w. prowincjałowie prowincji polskiej - doświadczonej przez kasaty i chylącej się ku upadkowi po powstaniu styczniowym - rezydowali w różnych klasztorach, m.in. w Krakowie, Klimontowie i Lublinie. Siedzibą prowincjała prowincji galicyjskiej stał się z kolei Lwów. Bieżące akta kancelarii prowincjałów z tego okresu musiano więc przechowywać we wspomnianych ośrodkach. Do przełożonych prowincji częściowo wpływały także szczątkowe archiwa klasztorów zniesionych przez władze zaborcze, np. w $1864 \mathrm{r}$. w posiadaniu prowincjała prowincji polskiej były akta konwentów w Horodle, Terespolu, Piotrkowie (Trybunalskim) i Poznaniu ${ }^{47}$. Materiały dotyczące całej prowincji, zgromadzone dotychczas w archiwum krakowskim, pozostały jednak na swoim dotychczasowym miejscu.

W XIX w. tematyka archiwistyczna pojawiała się w encyklikach prowincjałów. Przykładowo Mateusz Kozłowski - wówczas przełożony prowincji Galicji Zachodniej - 17 lipca 1808 r. polecił przeorom składanie jednego egzemplarza inwentarzy kościoła i klasztoru w archiwum klasztoru, a drugiego w archiwum prowincji ${ }^{48}$. Równocześnie nakazywał, by oryginały przywilejów i akt kapituł konwentu przechowywano w bezpiecznym miejscu ${ }^{49}$. Rozporządzenie dotyczące

${ }^{44}$ [List do redakcji „Ami de la Religion”], „Czas”, (1850) nr 184, s. 1.

${ }^{45}$ A. Grabowski, Wspomnienia, t. 2, Kraków 1909 (Biblioteka Krakowska, z. 41), s. 221-222, przypis 1 .

${ }^{46}$ Świętochowski, Źródta do dziejów, s. 85.

${ }^{47}$ APPD, sygn. Pp 3a/7, Spis Książek i Akt do Urzędu prowincyała X.X. Dominikanów należących [z 27 IV 1864 r.].

${ }^{48}$ APPD, sygn. Pp 44, Liber Encyclicarum Provinciae Poloniae Sacrae Ordinis Praedicatorum Sub Provincialatu Admodum Reverendis ac Eximii Patris Sacrae Theologiae Magistri Patris Basilii Barski Filij Conventus Cracoviensis Electi in Capitulo Posnaniensi Anno Domini 1765 Die 14 Septembris Sub Prioratu Admodum Reverendis ac Eximii Patris Sacrae Theologiae Magistri Patris Michaelis Barwiński Suppriore pro tunc existente Reverendi Admodum Patris Sacrae Theologiae Lectoris Patris Ludovico Kochmański Depositario Conventus [Cracoviensis] Inchoatus, s. 157.

${ }^{49}$ Tamże, s. 158. 
konieczności organizacji archiwów klasztornych sformułował także wyższy przełożony prowincji polskiej Damascen Szymborski w encyklice z 6 maja $1841 \mathrm{r}$. Odwoływał się w niej do postanowień kapituł generalnych z lat 1608 i $1611^{50}$.

Dominikańskie prawodawstwo nie nakazywało, by archiwa znajdowały się w odrębnych, przeznaczonych wyłącznie dla nich pomieszczeniach. $Z$ inwentarza kościoła i klasztoru Św. Trójcy sporządzonego w październiku 1820 r. wiadomo jednak, że archiwum (zapewne rozumiane zarówno jako archiwum prowincji wraz z kopiariuszami, jak i archiwum klasztoru) nie dzieliło już wspólnej przestrzeni z biblioteką. Znajdowało się w XIII-wiecznej sali, współcześnie nazywanej Skarbcem, z wejściem od strony atrium. Można postawić hipotezę, że w Krakowie archiwum złożono w osobnym pomieszczeniu jeszcze w drugiej połowie XVIII stulecia, na co wpływ miał rozwój studiów historycznych w zakonie i prowincji, wzrost świadomości znaczenia archiwaliów oraz powiększenie liczby zgromadzonych dokumentów, także w wyniku centralizacji akt. Komisja powołana przez władze Wolnego Miasta Krakowa w inwentarzu z 1820 r. zawarła krótki opis wnętrza archiwum, wskazujący na jego dobre zabezpieczenie:

Obok Szkoły [Teologicznej] w tymże kurytarzu jest Sklep czyli Archiwum do którego drzwi dubeltowe staroświeckiej struktury w odrzwiach kamiennych osadzone. Pierwsze z frontu skrzydlaste dębowe między ramami takiemiż na zawiasach i hakach z zamkiem polskim, drugie żelazne papami takiemiż wzmocnione, z zamkiem i hakami żelaznymi. Za tymi drzwiami sklep kwadratowy długości pięć, i szerokości tyleż sążni mający. Posadzka w nim ceglana, nadw[e]rężona, sklepienie murowane, okno jedno na wschód z szybek drobnych okrągłych na ołowiu w ramach drewnianych, na cztery kwatery podzielonych z kratą żelazną krzyżową, przy którym okiennica żelazna $\mathrm{z}$ dwóch połowin składająca się, na zawiasach i hakach żelaznych w węgarach kamiennych osadzonych ${ }^{51}$.

Samym archiwaliom poświęcono jednak tylko jedno zdanie:

W sklepie tym różne szafy z napisami, a w tych różne papiery i dokumenta tyczące się funduszów klasztornych zachowane, lecz porozrzucane i zaniedbane, wielkiej pracy i długiego czasu do uporządkowania potrzebują ${ }^{52}$.

Opis ten wyraźnie daje do zrozumienia, że archiwum pozbawione było troski i opiekuna, w czym kontrastowało choćby z uporządkowanym archiwum głównego klasztoru dominikańskiej prowincji ruskiej we Lwowie ${ }^{53}$. Nieco więcej informacji o zasobie - zwracających uwagę nie na jego stan i stopień opracowania, lecz

${ }^{50}$ Tamże, s. 234-235.

${ }^{51}$ APPD, sygn. Kr 41, Inwentarz Kościoła Zakonnego i Klasztoru Xięży Dominikanów w Gminie I-szej przy ulicy Szeroka zwanej w Wolnym Mieście Krakowie sytuowanego na mocy tak Rozporządzenia Wydziału Spraw Wewnętrznych w Senacie Rządzącym dnia 20 Mca Paźdr. Roku 1820, jako też Odezwy Konsystorza Jeneralnego Krakowskiego pod dniem. Mca. Roku tegoż 182. Nr uczynionych stosownie do Instrukcji w tey mierze wydaney przez Delegowanych Kommisarzy Cywilno Duchownych sporządzony. Opis czyli Inwentarz Kościoła S. Idziego, s. 94.

${ }^{52}$ Tamże.

${ }^{53}$ Archiwum Opactwa Cystersów w Mogile, sygn. 595, Diarium itineris provincialis a die $27^{\mathrm{ma}}$ Octobris anni 1806, s. 19 (fotokopia w APPD). 
wartość, podał zmarły w 1844 r. Wincenty Plebankiewicz. Zakonnik - określający archiwum klasztoru Św. Trójcy mianem ,skarbca przemożnego drogich pamiątek, historycznych przedmiotów" - zauważył, że we wspomnianym pomieszczeniu „wszystkie dowody, przywileje, Akta całej prowincyi polskich Dominikanów w najbezpiéczniejszem miejscu znajdują ocalenie" ${ }^{54}$. Słowa Plebankiewicza stanowią świadectwo ścisłego związku archiwum konwentu $\mathrm{z}$ archiwum prowincji.

Krakowski kościół i klasztor dominikanów 18 lipca 1850 r. padł ofiarą wielkiego pożaru miasta, w wyniku którego zostały zniszczone także gmach i zbiory biblioteki. Ambroży Grabowski twierdził, że spłonęły wówczas XVI-wieczne wielkoformatowe antyfonarze $\mathrm{z}$ miniaturami br. Wiktoryna ${ }^{55}$. Walerian Kalinka przekonany, że zasób archiwum przechowywany jest w bibliotece - ubolewał $\mathrm{z}$ kolei nad bezpowrotnym utraceniem ,wielu rękopismów i osobnego wolumenu dyplomatów z XIII, XIV i następnych stuleci do historyi narodu i kościoła odnoszących się" ${ }^{\prime 56}$. Informacje o zniszczeniu wymienionych materiałów powtarzano także w licznych pracach naukowych aż do końca XX wieku ${ }^{57}$. W rzeczywistości jednak pomieszczenie i zasób archiwum nie uległy zniszczeniu, podobnie jak wielkoformatowe księgi liturgiczne, które zapewne znajdowały się w Skarbcu ${ }^{58}$. Prawdopodobnie spłonęło jednak wiele rękopisów bibliotecznych, przechowywanych w klasztornej bibliotece.

W czasie odbudowy konwentu, w maju 1857 r., zdecydowano o przemianowaniu sali sąsiadującej z archiwum (obecnej auli) na refektarz; samo pomieszczenie archiwum stało się z kolei częścią jadalni ${ }^{59}$. Materiały archiwalne trafiły do nowej

${ }^{54}$ APPD, sygn. R. 784, Wincenty Plebankiewicz, Klasztor i Kościół OO. Dominikanów w Krakowie, w: Sadok Barącz, Materyały do napisania Monografii Krajowych, s. 17. Barącz cytuje to dzieło w pracy Klasztór i kościót Dominikanów w Krakowie, Poznań 1888, s. 65.

${ }^{55}$ A. Grabowski, Kraków i jego okolice, Kraków 1905, s. 153-154. Na rzekome zniszczenie antyfonarzy zwracano też uwagę w prasie, zob.: [List do redakcji „Ami de la Religion”], s. 1.

${ }^{56}$ W. Kalinka, Historya pożaru miasta Krakowa, Kraków 1850, s. 58.

${ }^{57}$ Jeszcze po ponad stu latach od pożaru klasztoru w 1850 r. niektórzy badacze byli przekonani, że krakowskie archiwum dominikanów spłonęło, i w związku z tym nie zwracali się do tej instytucji w czasie swoich badań. W 1977 r. archiwista prowincji Zygmunt Bruno Mazur apelował do Krystyny Zawadzkiej, by w pisanej przez nią pracy „,nie powtarzać bajek o spaleniu Archiwum w 1850 r., jakie niektórzy historycy do dzisiaj powielają”. Zob.: APPD, sygn. Kn 17, Korespondencja archiwisty z lat 1868-1956, s. 657 (R. Świętochowski, Archiwum OO. Dominikanów w Krakowie); APPD, sygn. Kn 24; Korespondencja archiwisty z lat 1973-1977, s. 341 (list o. Bruno Mazura do Krystyny Zawadzkiej z 22 I 1977 r.).

${ }^{58}$ Przekonanie o spłonięciu liturgików wielkoformatowych wynikało zapewne z lektury XVIIIwiecznych dzieł Michała Siejkowskiego i Felicjana Nowowiejskiego, którzy opisywali księgi chórowe przechowywane wówczas w bibliotece klasztoru krakowskiego. Zob.: Sieykowski, Światnica Pańska, s. 28; Nowowieyski, Phaenix decoris, s. 207.

${ }^{59}$ APPD, sygn. Kr 12, Incipit Liber Quartus Consiliorum Patrum in Conventu Cracoviensi Sanctissimae Trinitatis Ordinis Praedicatorum Anno Domini 1772 Die 16 Novembris. Triennium Prioratus peragente Adm. Rndo ac Eximio Patre Sacrae Theologiae Magistro Exprovinciali Patre Basilio Barski [et aliorum], s. 203; APPD, sygn. Kr 43, Inwentarz Kościoła i klasztoru OO. Dominikanów tudzież Kościoła św. Idziego w Krakowie (w r. 1875) spisany w roku 1874 wg instrukcji Namiestnictwa Wysokiego c. k. Namiestnictwa z dn. 6 lutego 1870 liczba 2070, s. 433. 
biblioteki, po pożarze składającej się z czterech cel na piętrze przylegających do pierwszego wirydarza. Świadczyć może o tym choćby obecność XIX-wiecznej pieczątki biblioteki klasztornej na kartach wielu jednostek archiwalnych. Ponadto w latach 60. XIX w. z archiwum znajdującego się w bibliotece korzystali: morawski benedyktyn Beda Dudík, badający archiwa galicyjskie, a także niemiecki historyk Colmar Grünhagen, poszukujący źródeł do historii Śląska. Pierwszy charakteryzując archiwum krakowskich braci kaznodziejów, wymienił w swej pracy ważniejsze średniowieczne i nowożytne rękopisy dostępne w bibliotece ${ }^{60}$. Grünhagen spędził kilka godzin za klauzurą dzięki pośrednictwu Teofila Żebrawskiego - od 1856 r. kierownika komitetu prokuracji (odbudowy) dominikańskiego kościoła Św. Trójcy. Dzięki życzliwości bibliotekarza uzyskał swobodny dostęp do nieuporządkowanych dokumentów, wśród których największe zainteresowanie wzbudziły w nim papieskie bulle z pierwszej połowy XIII w. ${ }^{61}$ Wspomniani badacze musieli nie być jedynymi gośćmi, skoro nieco ponad dekadę później „Przegląd Biblijograficzno-Archeologiczny" poda, że dominikańska biblioteka odznacza się porządkiem i dbałością o cenne zbiory, wśród których jest „wiele antyfonałów ładnie malowanych z początku XVI stulecia, dużo dokumentów, przywilejów i rachunków domowych, niezmiernie ciekawych do dziejów wewnętrznych dawnej Polski”' ${ }^{2}$. Wspomniany już Grünhagen z satysfakcją zwracał uwagę, że uzyskując dostęp do dominikańskiego archiwum, nie był zbywany rozpowszechnioną plotką o zniszczeniu cennych źródeł w czasie pożaru w 1850 r. ${ }^{63} \mathrm{~W}$ kontekście tych słów trudno zrozumieć, dlaczego inwentarz spisany przez władze austriackie w $1874 \mathrm{r}$. podał błędną informację o spłonięciu wszystkich dokumentów, przywilejów i nadań konwentu braci kaznodziejów, pod którą widnieją podpisy zakonników ${ }^{64}$. Być może fałszywe oświadczenie wynikało ze świadomości nieuporządkowania materiałów lub obawy przed obarczeniem niewielkiej wspólnoty dominikanów nakazem sporządzenia katalogu. Co ciekawe, inwentarz równocześnie opisuje pomieszczenie archiwum na pierwszym piętrze klasztoru, oddzielone od cel pełniących funkcję biblioteki zaledwie jednym mieszkaniem. Wspomniany „sklepiony pokoik o jednem starem pojedynczem oknie z podłogą ceglaną bez pieca" ${ }^{65}$ znajdował się przy wirydarzu pierwszego krużganka, na rogu korytarza głównego i korytarzyka przylegającego do oratorium i kaplicy św. Jacka. Niestety, autorzy inwentarza nie poświęcili uwagi jego wyposażeniu. Niewykluczone, że materiały

${ }^{60}$ B. Dudík, Archive im Königreiche Galizien und Lodomerien. Im Auftrage des hohen Staatsministeriums beschrieben und durchforscht, Wien 1868 (Archiv für österreichische Geschichte, t. 39), s. 51-58.

${ }^{61}$ C. Grünhagen, Bericht über eine archivalische Reise nach Krakau (Pfingsten 1868), „Zeitschrift des Vereins für Geschichte (und Alterthum) Schlesiens", 9 (1868) s. 136.

${ }^{62} \mathrm{~m}$, [Bibljoteki klasztorne w Krakowie], ,Przegląd Biblijograficzno-Archeologiczny”, t. 1, red.

C. Wilanowski, Warszawa 1881, s. 110.

${ }^{63}$ Grünhagen, Bericht über eine archivalische Reise, s. 136.

${ }^{64}$ APPD, sygn. Kr 43, Inwentarz Kościoła i klasztoru OO. Dominikanów tudzież Kościoła św. Idziego w Krakowie (w r. 1875) spisany w roku 1874 wg instrukcji Namiestnictwa Wysokiego c. k. Namiestnictwa z dn. 6 lutego 1870 liczba 2070, s. 393; zob. także s. 3.

${ }^{65}$ Tamże, s. 478. 
archiwalne sprzed pożaru konwentu złożono jednak w osobnym pomieszczeniu, ale traktowano je jako część biblioteki i dlatego rękopisy opatrzono bibliotecznymi pieczątkami.

Pod koniec XIX w. biblioteka klasztorna przeniesiona została do zachodniego skrzydła pierwszego wirydarza, który dotychczas pozostawał pusty ${ }^{66}$. Zachowane do dziś oryginalne półki pomieszczeń, służących współcześnie jako magazyny inkunabułów i starodruków, zawierają także zamykane szafki, w których mogły być przechowywane m.in. dokumenty pergaminowe i inne luźne akta. Niewykluczone jednak, że archiwum mieściło się we wspominanym już pomieszczeniu przy głównym korytarzu konwentu. W tym okresie jego nieformalnym opiekunem stał się brat konwers Kazimierz Jucewicz - organista, a z zamiłowania także bibliotekarz klasztoru. Zainteresowany historią dominikanów, czytał księgi i dokumenty oraz zostawiał na nich zapiski, w których określał datację, rozszyfrowywał autorów, charakteryzował zawartość rękopisów lub czynił własne uwagi. Dzięki doskonałej znajomości zasobu - pomimo jego nieuporządkowania - zapisał pięć ksiąg notatkami i wypisami ze źródeł, które stanowią ceny materiał dla badaczy biografii braci kaznodziejów oraz historii klasztorów i kultury dominikańskiej na ziemiach polskich ${ }^{67}$. Jucewicz udostępniał przy tym źródła historykom spoza zakonu, gdyż - jak trafnie zauważył R. Świętochowski - „rozumiał, że wartość biblioteki czy archiwum nie polega na samym posiadaniu, ale są po to, aby z nich obficie korzystano. Było to więc spojrzenie jak najbardziej nowożytne"68. Brat ten podjął się także katalogowania dyplomów pergaminowych z lat 1227-1476, a w 1913 r. sporządził spisy bibliotecznych antyfonarzy, psałterzy i graduałów ${ }^{69}$. Zakonnik pragnął ponadto gromadzić odpisy cennych dokumentów. Przykładowo powołując się na artykuł Władysława Abrahama o średniowiecznych polonikach w rzymskich archiwach i bibliotekach, zwrócił szczególną uwagę na trzy pliki akt luźnych z Archiwum Generalnego Zakonu Kaznodziejskiego w Rzymie o tytułach „Ex archivo conventus Cracovien. SS. Trinit. Ord. Pr. desumpta ac descripta...” z lat 1218-1300, 1301-1416 i 1420-1672 ${ }^{70}$. Ponieważ Jucewicz uznał, że chodzi o rodzaj nieznanej kroniki przytaczającej treść dokumentów z czasów św. Jacka,

${ }^{66}$ Świętochowski, Biblioteka oo. Dominikanów, s. 309.

${ }^{67}$ APPD, sygn. Kn 17, Korespondencja archiwisty z lat 1868-1956, s. 657 (R. Świętochowski, Archiwum OO. Dominikanów w Krakowie); APPD, sygn. Kn 1, Protokół czynności Archiwum Prowincji Polskiej OO. Dominikanów w Krakowie za Prowincjalstwa Przew. O. Dra Bernarda Przybylskiego, tom I, s. 4.

${ }^{68}$ Świętochowski, Biblioteka oo. Dominikanów, s. 309.

${ }^{69}$ APPD, sygn. Kn 45, Spis i streszczenie dyplomów pergam[inowych]. Spis antyfonarzy [spisy, regesty i odpisy dokumentów przechowywanych w archiwum i bibliotece klasztoru Dominikanów w Krakowie, sporządzone przez br. Kazimierza Jucewicza].

${ }^{70} \mathrm{~W}$. Abraham, Sprawozdanie z poszukiwań w archiwach i bibljotekach rzymskich do dziejów Polski w wiekach średnich za lata 1899-1913, w: Archiwum Komisji Historycznej, serja 2, t. 1, Kraków 1923 (Wydawnictwa Komisji Historycznej Polskiej Akademji Umiejętności, serja 2, nr 78), s. $55-56$. 
stwierdził, że „za wszelką cenę trzeba ją odpisać i do nasz[ego] archiw[um] sprowadzić" ${ }^{\prime \prime}$. Schorowany brat konwers nie zdążył jednak tego zrobić, gdyż na rok przed śmiercią, w 1924 r. zakończył pracę jako opiekun klasztornego archiwum i biblioteki ${ }^{72}$.

K. Jucewicz nie był jedynym dobroczyńcą klasztornego archiwum w tym okresie. W 1897 r. Wincenty Podlewski wraz z kilkudziesięcioma książkami przywiózł do Krakowa niewielką część archiwum ze zniesionego przez carat konwentu św. Jacka w Warszawie ${ }^{73}$. Zakonnik w 1899 r. posłał ponadto „,paczkę papierów i ksiąg przeważnie rachunkowych klasztoru gidelskiego", a kolejną partię materiałów w $1901 \mathrm{roku}^{74}$. Wcześniej, jako przeor krakowski (1877-1880), miał także zainicjować gromadzenie zbioru ikonografii ${ }^{75}$. Inną ważną postacią dla archiwum stał się Jacek Woroniecki, przebywający w Krakowie od 1914 r., a do 1919 r. pełniący urząd bibliotekarza konwentu. Wybitny tomista, erudyta, wielbiciel ojczystego języka i historii, musiał zdawać sobie sprawę z wartości źródeł zgromadzonych $\mathrm{w}$ archiwum i dlatego podjął się porządkowania jego zasobu. Zabezpieczył dokumenty pergaminowe przez włożenie ich do opisanych kopert (z których setki spełniają swą rolę po dzień dzisiejszy); jako daty tych prac podaje się ok. $1914 \mathrm{r}$. lub lata 1916-191776. Zdaniem Wiesława Müllera, J. Woroniecki zajął się także kopiariuszami z początku XVII w. i „uporządkował je tworząc osobne teczki dla poszczególnych konwentów" "77. Można więc wnioskować, że zakonnik wyłączył kopiarze z akt urzędu prowincjalnego prowincji polskiej i dołączył je do albo już istniejących, albo do nowo utworzonych szczątkowych zespołów poszczególnych klasztorów. Woroniecki sporządził na małych kartkach notatki na temat braci

${ }^{71}$ APPD, sygn. Kn 45, Spis i streszczenie dyplomów pergam[inowych]. Spis antyfonarzy [spisy, regesty i odpisy dokumentów przechowywanych w archiwum i bibliotece klasztoru Dominikanów w Krakowie, sporządzone przez br. Kazimierza Jucewicza], s. 430. Krytyka zewnętrzna wspomnianych źródeł wskazuje na ich powstanie w okresie nowożytnym.

${ }^{72}$ Świętochowski, Biblioteka oo. Dominikanów, s. 311.

${ }^{73}$ Tamże, s. 308; APPD, sygn. Kr 907, K. Jucewicz, Okruszyny biograficzne o niektórych znakomitych Ojcach Z. Kazn. prowincji polskiej i spis prowincjałów od r. 1609 do 1864 r. jako też i OO. Przeorów krakowskich, s. 352; APPD, sygn. R. 560, Historia o św. Dominiku i zakonie Jego (cz. 1) [zapiski o. Wincentego Podlewskiego na wewnętrznej stronie okładki], kk. nlb.

${ }^{74}$ APPD, sygn. Kr 907, K. Jucewicz, Okruszyny biograficzne o niektórych znakomitych Ojcach Z. Kazn. prowincji polskiej i spis prowincjałów od r. 1609 do 1864 r. jako też i OO. Przeorów krakowskich, s. 352; APPD, sygn. Kn 17, Korespondencja archiwisty z lat 1868-1956, s. 25-26 (list o. Wincentego Marii Podlewskiego do o. Czesława Mączki z 17 III 1899 r.), 27-28 (list o. Wincentego Marii Podlewskiego do o. Czesława Mączki z 20 VIII 1901 r.).

${ }^{75}$ Świętochowski, Biblioteka oo. Dominikanów, s. 308.

${ }^{76}$ APPD, sygn. Kn 1, Protokół czynności Archiwum Prowincji Polskiej OO. Dominikanów w Krakowie za Prowincjalstwa Przew. O. Dra Bernarda Przybylskiego, tom I, s. 4; APPD, sygn. Kn 17, Korespondencja archiwisty z lat 1868-1956, s. 460 ([R. Świętochowski], Krótki referat o pracach i stanie Archiwum Prowincji Polskiej OP, 1950 r.); K. Kalinowska, Jacek Woroniecki o spoteczeństwie i państwie, Lublin 2005, s. 35-36.

${ }^{77}$ W. Müller, Kopiariusze konwentów dominikańskich w Archiwum OO. Dominikanów w Krakowie [komunikat], „Sprawozdania z Czynności Wydawniczej i Posiedzeń Naukowych oraz Kronika Towarzystwa Naukowego Katolickiego Uniwersytetu Lubelskiego", (1961) nr 11, s. 98. 
pojawiających się w kolejnych źródłach, które prawdopodobnie zostały później dołączone przez R. Świętochowskiego do kartoteki biograficznej dominikanów polskich. Wybitny tomista zapewne w tym okresie zwrócił także uwagę na znajdujący się w zasobie archiwum zbiór formuł polskiej prowincji dominikanów z lat 1338-1411, który przedłożył do opracowania i druku Janowi Fijałkowi ${ }^{78}$. Choć J. Woroniecki nie był członkiem konsylium konwentu krakowskiego, przypuszczalnie przyczynił się do podjęcia przez radę 15 czerwca $1918 \mathrm{r}$. jednogłośnej decyzji o organizacji archiwum zgodnie $\mathrm{z}$ wytycznymi nauki (,,archivum Conventus Cracoviensis scientifice ordinare et disponere"). Praca ta miała zostać wykonana przez profesora uniwersyteckiego we współpracy z bibliotekarzem, czyli samym Woronieckim $^{79}$. Ambitne plany zostały jednak szybko pokrzyżowane, gdyż zakonnik w 1919 r. objął profesurę teologii moralnej na Uniwersytecie Lubelskim (późniejszym KUL-u).

Po odzyskaniu niepodległości przez Rzeczpospolitą, prowincję galicyjską zaczęto określać mianem „Prowincji św. Jacka w Polsce”. Prowincja polska, obejmująca teren całego kraju, przywrócona została formalnie w 1927 r., ale już rok wcześniej na kapitule prowincjalnej w Krakowie ustanowiono urząd archiwariusza prowincji. Najpewniej jego zadaniem była opieka nad aktami powstałymi w wyniku działalności kancelarii prowincjalskiej we Lwowie, być może także z czasów istnienia prowincji galicyjskiej. Oficjum ${ }^{80}$ pełnili jednak także zakonnicy asygnowani i pracujący w innych klasztorach. Archiwariuszami prowincji byli kolejno: Fabian Madura (1926-1930, przebywający kolejno w Krakowie, Lwowie i ponownie w Krakowie) $)^{81}$, Zygmunt Ogarek (1930-1934, we Lwowie, a na-

${ }^{78}$ Zbiór formut Zakonu Dominikańskiego.

${ }^{79}$ APPD, sygn. Kr 791, Liber Consiliorum Conventus Cracoviensis FF. Ord. Praedicatorum A. 1888, s. 384-385.

${ }^{80}$ Oficjum (łac. officium) to w Zakonie Kaznodziejskim urząd oraz wiążące się z nim obowiązki. Wyróżnić można oficjalistów zakonu, prowincji, konwentu, studium, nowicjatu, studentatu itp.

${ }^{81}$ APPD, sygn. S 44/10a, Acta Capitulorum Provinciae Poloniae Ordinis Praedicatorum, t. 4: ab anno 1801-1863 et ab anno 1920-1978, oprac. R.F. Madura, k. 204. Fabian (z chrztu Roman) Madura (1892-1989) wstąpił do Zakonu Kaznodziejskiego w 1908 r., a święcenia kapłańskie przyjął w 1915 r. Studiował we Lwowie, Rzymie i Wiedniu. Pracował m.in. jako wykładowca Studium Dominikanów w Krakowie i Lwowie (od 1918), syndyk konwentu w Krakowie (1928-1933), przeor klasztorów w Tarnopolu (1933-1937), Tarnobrzegu (1939-1945), Gdańsku (1945-1953), Gidlach (1955-1956), Warszawie na Służewie (1956-1958), Warszawie przy ul. Freta (1963-1964) oraz proregens (1957-1958) i regens (1958-1963) Studium Generalnego w Krakowie. Założył chóry kościelne we Lwowie i Gdańsku, kierował nimi w Krakowie, Tarnopolu i Tarnobrzegu. W 1958 r. otrzymał tytuł magistra teologii. W latach 1964-1973 prowadził badania naukowe $w$ archiwach rzymskich. Po powrocie z Wiecznego Miasta przebywał w klasztorach w Krakowie (1973-1978) i Warszawie przy ul. Freta (1978-1989). Dziełem jego życia stały się edycje akt kapituł prowincji polskiej, ruskiej, litewskiej i galicyjskiej, opracowane w wyniku kwerend w Warszawie, Krakowie i Rzymie. Zob. m.in.: J.A. Spież, Madura Fabian Roman, w: Stownik polskich teologów katolickich (dalej: SPTK), t. 8, red. J. Mandziuk, Warszawa 1995, s. 356-357; W. Szymborski, Ze Lwowa poprzez Włochy, Austrię do odrodzonej Polski - sylwetka i dorobek naukowy O. Romana Fabiana Madury, „Res Gestae", 4 (2017) s. 96-121. 
stępnie w Podkamieniu) ${ }^{82}$ i Andrzej Gmurowski (1934-1938, we Lwowie, a później na podwarszawskim Służewie) ${ }^{83}$. Wspomniani dominikanie w czasie pracy we Lwowie zazwyczaj byli także bibliotekarzami konwentu. W czasie kapituły prowincjalnej w Krakowie w 1938 r. po raz pierwszy archiwariuszem prowincji został mianowany Robert Świętochowski, asygnowany do klasztoru w Żółkwi ${ }^{84}$.

${ }^{82}$ APPD, sygn. S 44/10a, Acta Capitulorum Provinciae Poloniae Ordinis Praedicatorum, t. 4: ab anno 1801-1863 et ab anno 1920-1978, oprac. R.F. Madura, k. 222. Zygmunt (z chrztu Julian) Ogarek (1886-1955) wstąpił do Zakonu Kaznodziejskiego w 1903 r., a święcenia kapłańskie przyjął w 1909 roku. Studiował we Lwowie, Louvain i Fryburgu Szwajcarskim; doktorat z filozofii uzyskał w 1920, a z teologii w 1932 roku. Pracował m.in. jako magister kleryków, wykładowca w Studium oo. Dominikanów i bibliotekarz we Lwowie (1911-1914), kapelan wojskowy w armii austriackiej (w czasie I wojny światowej), profesor w Seminarium Duchownym w Lublinie oraz na Uniwersytecie Lubelskim (późniejszym KUL 1922-1925), duszpasterz w Tarnopolu (1926-1929) i Podkamieniu (1929-1930), dyrektor wydawnictw dominikańskich i wykładowca w Studium oo. Dominikanów we Lwowie (1930-1933), administrator parafii w Podkamieniu (1934), katecheta i wikariusz parafii w Bohorodczanach (1935-1937), katecheta i bibliotekarz w Tarnobrzegu (1937-ok. 1939), duszpasterz w Borku Starym (w czasie II wojny światowej) oraz katecheta w Prudniku (1947-1948). Ostatnie lata życia spędził w Gidlach (1948-1952) i Poznaniu (1952-1955). Zob. m.in.: R. Świętochowski, Ogarek Julian Jan Zygmunt, PSB, t. 23, red. E. Rostworowski, Wrocław 1978, s. 588-589; Z. Mazur, Ogarek Zygmunt Julian Jan, SPTK, t. 6, red. L. Grzebień, Warszawa 1983, s. 577-578.

${ }^{83}$ APPD, sygn. S 44/10a, Acta Capitulorum Provinciae Poloniae Ordinis Praedicatorum, t. 4: ab anno 1801-1863 et ab anno 1920-1978, oprac. R.F. Madura, k. 243. Andrzej (z chrztu Florian) Gmurowski (1901-1944) wstąpił do Zakonu Kaznodziejskiego w 1921, a święcenia kapłańskie przyjął w 1925 r. Studiował w Kain (Belgia) i we Lwowie; doktorat z teologii uzyskał w 1928 r., a habilitację w 1936 r. Pracował m.in. jako wykładowca w Studium Dominikanów we Lwowie (1926-1939) i na Wydziale Teologicznym Uniwersytetu Warszawskiego (1937-1939), przełożony w Jarosławiu oraz duszpasterz powstańców warszawskich w czasie II wojny światowej. W 1932 r. otrzymał tytuł magistra teologii. Zob. m.in.: J. Woroniecki, Gmurowski Andrzej Florian, PSB, t. 8, red. W. Konopczyński, Wrocław 1959-1960, s. 137; Z. Mazur, Gmurowski Andrzej Florian, SPTK, t. 5, red. L. Grzebień, Warszawa 1983, s. 454-456.

${ }^{84}$ APPD, sygn. S 44/10a, Acta Capitulorum Provinciae Poloniae Ordinis Praedicatorum, t. 4: ab anno 1801-1863 et ab anno 1920-1978, oprac. R.F. Madura, k. 283. Robert (z chrztu Walery) Świętochowski (1907-1978) wstąpił do Zakonu Kaznodziejskiego w 1925 r., a święcenia kapłańskie przyjął w 1933 r. Studiował we Lwowie i Lublinie; przygotowywał także pracę doktorską na KUL, która nie uzyskała akceptacji promotora. Pracował w charakterze archiwisty klasztoru (od 1935) i prowincji (od 1938) we Lwowie, a w czasie II wojny światowej jako duszpasterz i katecheta w Lublinie, Jarosławiu, Żółkwi i Czortkowie. Po jej zakończeniu był archiwistą konwentu w Jarosławiu (od 1945), po raz drugi archiwistą (i bibliotekarzem) prowincji w Krakowie (1946-1951), wikariuszem parafii w Prudniku, katechetą w Gidlach (1949-1950) oraz Gdańsku (1954-1958). Następnie przebywał w Borku Starym (1958-1959) i ponownie w Krakowie (1959-1978), gdzie po raz trzeci został archiwistą prowincji (1961-1973), a ponadto wykładowcą w Studium Dominikanów (od 1961). W 1952 r. funkcjonariusze Urzędu Bezpieczeństwa podjęli się próby jego werbunku; został zarejestrowany jako informator o pseudonimie „Gażyn” lub „Gażym”, jednak odmówił dalszych kontaktów po trzech spotkaniach. W latach 60 . XX w. stworzył muzeum w klasztorze w Gidlach. Określał siebie mianem ostatniego żyjącego Prusa („ultimus Pruthenorum”). Znając doskonale zasób archiwum prowincji, opublikował ponad 130 artykułów naukowych, biogramów, sprawozdań i komunikatów dotyczących stanu badań nad źródłami do dziejów dominikanów na ziemiach polskich. Zob. m.in.: Z. Mazur, Świętochowski-Sapek Robert Walery, SPTK, t. 7, red. L. Grzebien, 
Jak sam twierdził, w praktyce swe oficjum pełnił jednak zaledwie przez dwa miesiące ${ }^{85}$.

O rosnącej wśród polskich dominikanów świadomości znaczenia archiwaliów w okresie II Rzeczpospolitej świadczą postanowienia kapituł w Krakowie (1926) i Lwowie (1934). Pierwsza zarządziła, by wszystkie stare dokumenty i księgi odnoszące się do historii zakonu i konwentów, które zwłaszcza w małych klasztorach nie są używane, przekazywano do archiwum prowincji we Lwowie. Bracia kaznodzieje argumentowali to postanowienie bolesnymi doświadczeniami I wojny światowej, kiedy zniszczeniu i spaleniu miało ulec wiele dokumentów ${ }^{86}$. Druga kapituła polecała przełożonym konwentów utrzymywanie archiwów klasztornych $\mathrm{w}$ idealnym porządku, zaś prowincjała zobowiązywała do ich odwiedzania w czasie wizytacji kanonicznych. Postanowienie to z jeszcze większym naciskiem miało odnosić się do archiwum prowincji ${ }^{87}$. Kapitulariusze zarządzili ponadto, by do archiwów historycznych (,archiva historica”) klasztorów w Krakowie i Lwowie trafiały cenne, wiekowe dokumenty z innych konwentów; dwa wymienione archiwa miały być $\mathrm{z}$ kolei lepiej zorganizowane i chronione ${ }^{88}$. Niewykluczone, że na przyjęcie wspomnianych zapisów duży wpływ miał Jacek Woroniecki, uczestnik obrad i nowy socjusz prowincjała.

Prawdopodobnie pod wpływem postanowień kapituły we Lwowie, w $1936 \mathrm{r}$. konsylium klasztoru krakowskiego - po raz pierwszy w najnowszej historii prowincji - ustanowiło osobne oficjum archiwisty konwentu. Najpierw, 15 czerwca został nim Jan Bryk, a 21 października Anzelm Jezierski (będący także bibliotekarzem $)^{89}$. W czasie urzędowania drugiego $\mathrm{z}$ wymienionych, rada konwentu 18 maja 1937 r. podjęła decyzję o przebudowie i adaptacji pod archiwum dwóch połączonych ze sobą pomieszczeń z sanitariatami, tuż obok biblioteki. Na prace w południowo-zachodnim narożniku pierwszego wirydarza przeznaczono łącz-

Warszawa 1983, s. 297-302; T. Gałuszka, Świętochowski (Świętochowski-Sapek) Walery, PSB, t. 51, red. A. Romanowski, Warszawa-Kraków 2016-2017, s. 513-514; J. Puciłowski, Portrety imienne $i$ bezimienne. Polscy dominikanie a bezpieka 1945-1989, Kraków 2017, s. 175-176; W. Szymborski, Krakowscy dominikanie $i$ ich wkład $w$ rozwój historiografii polskiej, w: Krakowskie środowisko historyczne XV-XX w. Ludzie - idee - dzieła, red. T. Gąsowski, J. Smołucha, Kraków 2018, s. 309322, 337-338.

${ }^{85}$ APPD, Kn 17, Korespondencja archiwisty z lat 1868-1956, s. 459 ([R. Świętochowski], Przeszkody pracy archiwalnej, [1950 r.]).

${ }^{86}$ APPD, sygn. S 44/10a, Acta Capitulorum Provinciae Poloniae Ordinis Praedicatorum, t. 4: ab anno 1801-1863 et ab anno 1920-1978, oprac. R.F. Madura, k. 211. Już wcześniej, bo na kapitule prowincjalnej w Krakowie w 1913 r. postanowiono, by małe klasztory i domy zakonne przekazywały swoje archiwa do archiwum prowincji we Lwowie. Zob.: APPD, sygn. S 44/12b, Acta Capitulorum: 3. Provinciae Galiciae Orientalis (Galiciae et Lodomeriae) ab anno 1780 ad a. 1916, t. 6, oprac. R.F. Madura, k. 591, 594.

${ }^{87}$ APPD, sygn. S 44/10a, Acta Capitulorum Provinciae Poloniae Ordinis Praedicatorum, t. 4: ab anno 1801-1863 et ab anno 1920-1978, oprac. R.F. Madura, k. 265.

${ }^{88}$ Tamże, k. 266.

${ }^{89}$ APPD, sygn. Kr 791, Liber Consiliorum Conventus Cracoviensis FF. Ord. Praedicatorum A. 1888, s. 581, 591; APPD, sygn. Kr 842, Kronika Klasztoru krakowskiego OO. Dominikanów przy kościele św. Trójcy od r. 1926, s. 49, 53. 
nie $2000 \mathrm{zt}^{90}$. Wiadomo, że remont trwał już na początku czerwca, a w połowie miesiąca gotowe były żelazne drzwi, łączące bibliotekę $\mathrm{z}$ archiwum ${ }^{91}$. Konsylium klasztoru 6 września przeznaczyło kolejne $300 \mathrm{zł}$ na sporządzenie - zapewne drewnianych - półek $^{92}$. Tym samym archiwum po wielu zmiennych losach uzyskało w końcu własne, służące mu do dziś magazyny. Zdaniem R. Świętochowskiego, A. Jezierski przekazał także kilka ksiąg do oprawy konserwatorskiej ${ }^{93}$. Rada konwentu 12 lutego 1938 r. wyznaczyła na bibliotekarza Dionizego Janiszewskiego; kronika klasztorna podaje, że został on zarazem archiwistą, o czym jednak milczy księga konsyliów ${ }^{94}$.

Tuż przed wybuchem II wojny światowej przeor Stanisław Hayto wywiózł do Lublina 110 krakowskich dyplomów pergaminowych z lat 1227-1433 oraz sześć ksiąg uchwał konsyliów konwentu krakowskiego i prowincji polskiej ${ }^{95}$. Herbert Mehlhorn skonfiskował akta i przewiózł je do Archiwum Państwowego (Staatsarchiv) przy ul. Grodzkiej w Krakowie. Od września 1943 r. do 24 sierpnia 1944 r. ówczesny pracownik archiwum Kazimierz Kaczmarczyk zinwentaryzował dyplomy pergaminowe z lat 1227-1894 ${ }^{96}$. Oznacza to, że do Archiwum Państwowego prawdopodobnie trafily także pergaminy z okresu po 1433 r. Po wybuchu wojny prowincjał przeniósł się ze Lwowa do Krakowa, a oficjum archiwariusza prowincji nie zawsze było formalnie obsadzane. W styczniu 1940 r. i 1941 r. kronika konwentu krakowskiego wskazywała jako archiwistę klasztoru, biblioteka-

${ }^{90}$ APPD, sygn. Kr 791, Liber Consiliorum Conventus Cracoviensis FF. Ord. Praedicatorum A. 1888, s. 604; APPD, sygn. Kr 842, Kronika Klasztoru krakowskiego OO. Dominikanów przy kościele św. Trójcy od r. 1926, s. 61.

${ }^{91}$ APPD, sygn. Kr 1037/2, Rachunki i kwity klasztoru OO. Dominikanów w Krakowie, 16581946, kk. nlb. (potwierdzenie odbioru pieniędzy przez Karola Haytę za pracę w archiwum, 9 VI 1937 r. oraz rachunek od Zakładu Ślusarskiego Długosz i Proszowski za wykonanie drzwi do przejścia z biblioteki do archiwum, 16 VI 1937 r.).

${ }^{92}$ APPD, sygn. Kr 791, Liber Consiliorum Conventus Cracoviensis FF. Ord. Praedicatorum A. 1888, s. 611; APPD, sygn. Kr 842, Kronika Klasztoru krakowskiego OO. Dominikanów przy kościele św. Trójcy od r. 1926, s. 63.

${ }^{93}$ APPD, sygn. Kn 1, Protokół czynności Archiwum Prowincji Polskiej OO. Dominikanów w Krakowie za Prowincjalstwa Przew. O. Dra Bernarda Przybylskiego, tom I, s. 4.

${ }^{94}$ APPD, sygn. Kr 842, Kronika Klasztoru krakowskiego OO. Dominikanów przy kościele św. Trójcy od r. 1926, s. 70; APPD, sygn. Kr 791, Liber Consiliorum Conventus Cracoviensis FF. Ord. Praedicatorum A. 1888, s. 624.

${ }^{95}$ APPD, sygn. Kn 17, Korespondencja archiwisty z lat 1868-1956, s. 167 (poświadczenie o. Łucjana Wołka, 27 VIII 1939 r.). Adam Kamiński podaje informację o 8 księgach z lat 1365-1796, zob.: Zarys dziejów Archiwum Państwowego w Krakowie (1792) 1878-1952, Kraków 2012 (Biblioteka Krakowska, nr 156), s. 118, przypis 5.

${ }^{96}$ APPD, sygn. Kn 46, Regesty 531 pergaminów OO. Dominikanów krakowskich z lat 1227 1894 zinwentaryzowanych przez dyrektora Archiwum Państwowego w Poznaniu dra Kazimierza Kaczmarczyka od września 1943 do sierpnia 1944. Katalog kartkowy 110 krakowskich dyplomów pergaminowych z lat 1227-1433 znajduje się ponadto w zespole archiwalnym Archiwum Rzeszy w Poznaniu, zob: Archiwum Państwowe w Poznaniu, sygn. 5663/0/-/219, Informatory o materiałach archiwalnych innych instytucji: Dominikaner Kloster in Krakau, Urkunden Nr 1-110. 
rza Dionizego Janiszewskiego ${ }^{97}$. Jego następcą został Jozafat Dawiskiba, jednak kronika nie wspomina o oficjum archiwisty konwentu w wykazie dominikanów z początku 1942 r. W kwietniu 1942 r. kapituła prowincji obradująca w Krakowie wybrała na urząd archiwariusza prowincji Efrema Glińskiego ${ }^{98}$. Gdy w $1944 \mathrm{r}$. klasztorowi groziło wysiedlenie, zakonnik miał odpowiadać za zabezpieczenie jego archiwum ${ }^{99}$. Wtedy też bł. Michał Czartoryski postulował, że inwentarz archiwum -

najcenniejszych pergaminów, dokumentów starych i nowych itp. koniecznie musi być zrobiony, chociażby pobieżny, ryczałtowy, ale wszystkiego co będzie schowane, czy jakkolwiek zabezpieczone jako archiwum Konwentu ${ }^{100}$.

Do wysiedlenia klasztoru ostatecznie nie doszło. Przyszły męczennik pozostawił po sobie jednak kilka inwentarzy dóbr ruchomych konwentu; z jednego $\mathrm{z}$ nich dowiadujemy się, że w lutym $1944 \mathrm{r}$. w magazynie archiwalnym przechowywano 10 obrazów ołtarzowych malowanych na desce ${ }^{101}$.

\section{Historia Archiwum Polskiej Prowincji Dominikanów w Krakowie}

W obecnym kształcie Archiwum Polskiej Prowincji Dominikanów w Krakowie zaczęło być organizowane od 1947 r. Duży wpływ na ten proces miała ewakuacja ogromnej liczby materiałów archiwalnych z klasztorów na Kresach południowo-wschodnich. W maju 1946 r. ze Związku Sowieckiego wywieziono wraz z biblioteką archiwum dominikanów lwowskich, lokując je w Krakowie i Poznaniu ${ }^{102}$. Do najstarszego konwentu prowincji trafiły także materiały z klasztoru w Czortkowie oraz z domów zakonnych w Podkamieniu, Żółkwi, Jezupolu, Bohorodczanach i Tarnopolu; prawdopodobnie wiele materiałów zaginęło jednak w czasie transportów. Prowincjał Bernard Przybylski wkrótce potem polecił wszystkim klaszto-

${ }^{97}$ APPD, sygn. Kr 842, Kronika Klasztoru krakowskiego OO. Dominikanów przy kościele św. Trójcy od r. 1926, s. 101, 129.

${ }^{98}$ APPD, sygn. S 44/10a, Acta Capitulorum Provinciae Poloniae Ordinis Praedicatorum, t. 4: ab anno 1801-1863 et ab anno 1920-1978, oprac. R.F. Madura, k. 300. Efrem (z chrztu Kazimierz Felicjan) Gliński (1910-1953) wstąpił do Zakonu Kaznodziejskiego w 1929 r., a święcenia kapłańskie przyjął w 1935 r. Studiował we Lwowie i Rzymie; doktorat z teologii uzyskał w 1946 r. Pracował m.in. jako wykładowca Studium Dominikanów na podwarszawskim Służewie i w Krakowie (od 1937), asystent-woluntariusz i starszy asystent na Wydziale Teologicznym Uniwersytetu Jagiellońskiego (1945-1947), notariusz w procesach beatyfikacyjnych Jadwigi Andegaweńskiej, Celiny Borzęckiej i Urszuli Ledóchowskiej oraz spowiednik i rekolekcjonista sióstr zakonnych. Zmarł w wyniku porażenia prądem. Zob.: Z. Mazur, Gliński Efrem Kazimierz Felicjan, SPTK, t. 5, red. L. Grzebień, Warszawa 1983, s. 447-449.

${ }^{99}$ APPD, sygn. S 3/5, Materiały dotyczące działalności O. Michała Czartoryskiego, s. 218 (Program zajęć [na wypadek ewakuacji, 1943 lub 1944 r.]).

${ }^{100}$ Tamże, s. 219 (odpis pisma o. Michała Czartoryskiego do przeora o. Czesława Mende ws. wysiedlenia klasztoru, 1 I 1944 r.).

${ }^{101}$ APPD, sygn. Kr 405, Inwentarz obrazów w Konwencie Św. Trójcy. Kraków I. 1944, s. 57.

${ }_{102}$ Z. Mazur, Dominikanie we Lwowie (1939-1946), „Tygodnik Powszechny”, (1990) nr 38, s. 4-5; M. Matwijów, Walka o lwowskie dobra kultury w latach 1945-1948, Wrocław 1996, s. $123-$ $124,130-131$. 
rom prowincji przekazanie do Krakowa materiałów archiwalnych powstałych do końca XIX w. Jeden z jego następców - Edmund Sochacki - w 1959 r. przesunął tę cezurę do 1927 r., czyli daty przywrócenia prowincji polskiej ${ }^{103}$. W praktyce do archiwum zaczęły jednak napływać także akta z pierwszej połowy XX w. z konwentów w powojennych granicach Polski, co wynikało z troski o ich stan zachowania. W 1963 r. Świętochowski pisał:

Konstytucje Zakonu Kaznodziejskiego przewidują i dają prawo każdemu klasztorowi, aby posiadał i prowadził własne archiwum. Ponieważ jednak w naszych klasztorach archiwalia nie zawsze były w poszanowaniu i nie zawsze miały warunki do wzorowej konserwacji, Archiwum centralne w Krakowie drogą polubownego układu z poszczególnymi przeorami w różnych czasach pościągało akta i dokumenty klasztorne do Krakowa (...). Traktuje się je zawsze jako depozyty, które może już nie powrócą do macierzystych klasztorów ${ }^{104}$.

W trakcie obrad kapituły prowincjalnej w Krakowie w grudniu 1946 r., Robert Świętochowski formalnie otrzymał oficjum archiwisty i bibliotekarza prowincji ${ }^{105}$. Do jego obowiązków miała należeć opieka nie tylko nad archiwum prowincji, lecz także biblioteką konwentu, rękopisami bibliotecznymi i starodrukami. Dominikanin objął urząd 2 stycznia 1947 r. i szybko zapoczątkował proces ewidencjonowania jednostek archiwalnych. W grudniu 1947 r. zakupił papier pakunkowy na kartotekę inwentarza, a rok później Drukarnia Związkowa przysłała mu 5.000 kart inwentarzowych ${ }^{106}$. Zakonnik nadał większości jednostek robocze sygnatury. Prowadził także prace nad tworzeniem tzw. fiszek, czyli kartoteki biograficznej dominikanów polskich, mającej odnotowywać wszystkich braci występujących w źródłach archiwalnych na przestrzeni wieków. Tworzenie krótkich życiorysów zmarłych zakonników poleciła mu zresztą kapituła prowincjalna w 1946 r. ${ }^{107}$ Wiadomo, że w 1947 r. R. Świętochowski utworzył osobne działy dla kartografii, grafiki, mikrofilmów i fotokopii; do działu kartograficznego trafiły - ze względów praktycznych (duże formaty) - wyłącznie zwoje i tzw. extranea ${ }^{108}$. Oprócz

${ }^{103}$ Biblioteka Kolegium Filozoficzno-Teologicznego Polskiej Prowincji Dominikanów w Krakowie (dalej: BDKr), bez sygn., Projekt uchwał dla Konsilium Prowincji w dniu 18.2.1959 r. w sprawie archiwum i bibliotek prowincji, k. nlb. Dziękuję mgr Małgorzacie Habudzie za udostępnienie niniejszego dokumentu.

${ }^{104}$ APPD, sygn. Kn 20, Korespondencja archiwisty z lat 1963-1965, s. 5 (pismo o. Roberta Świętochowskiego do przełożonego o. Rajmunda Koperskiego i Rady Klasztoru oo. Dominikanów w Tarnobrzegu z 3 I 1963 r.).

${ }^{105}$ APPD, sygn. S 44/10a, Acta Capitulorum Provinciae Poloniae Ordinis Praedicatorum, t. 4: ab anno 1801-1863 et ab anno 1920-1978, oprac. R.F. Madura, k. 318.

${ }^{106}$ APPD, sygn. Kn 1, Protokół czynności Archiwum Prowincji Polskiej OO. Dominikanów w Krakowie za Prowincjalstwa Przew[ielebnego] O. Dra Bernarda Przybylskiego tom I [rejestr czynności za lata 1947-1955, 1959-1962], s. 6, 12.

${ }^{107}$ APPD, sygn. S 44/10a, Acta Capitulorum Provinciae Poloniae Ordinis Praedicatorum, t. 4: ab anno 1801-1863 et ab anno 1920-1978, oprac. R.F. Madura, k. 329.

${ }^{108}$ APPD, sygn. Kn 22, Korespondencja archiwisty z lat 1969-1971, s. 21 (R. Świętochowski, Odpowiedź na ankietę dotyczącą zbiorów kartograficznych). Przez „extranea” rozumiano materiały niewytworzone w ramach działalności dominikanów. 
udostępniania jednostek badaczom (w rozmównicach oraz drogą wypożyczeń na zewnątrz), ważnym obowiązkiem archiwisty stało się wykonywanie odpisów metryk parafialnych, głównie dla wiernych pochodzących z dawnych parafii dominikańskich we Lwowie, Podkamieniu i Czortkowie. Świętochowski organizował archiwum niemal od podstaw, napotykając niekiedy na zaskakujące przeszkody, np. w czasie remontów cel zakonnych w 1947 r. „,chwilowo zaginą” katalog dyplomów pergaminowych, opracowany przez K. Kaczmarczyka ${ }^{109}$. Wspomnianym remontem była zapewne adaptacja dotychczasowych pustych pomieszczeń przy korytarzyku przylegającym do kaplicy św. Jacka na cztery cele zakonne, z których trzy służą współcześnie jako gabinety archiwalne ${ }^{110}$. Prawdopodobnie już wówczas R. Świętochowski zamieszkał w ostatnim z pomieszczeń, z którego drzwi prowadzą wprost do głównego magazynu archiwum.

Dużym sukcesem dominikanina było odzyskanie części archiwum krakowskiego zagrabionego przez Niemców, a następnie przechowywanego w Archiwum Państwowym w Krakowie. Jesienią 1947 r. zakonnik wniósł podanie do dyrektora instytucji Włodzimierza Budki z prośbą o zwrot akt, które przekazano 4 listopada tego samego roku ${ }^{111}$. Zasób archiwum powiększył się ponadto o materiały z innych konwentów. W październiku 1947 r. sprowadzono szczątkowe archiwum klasztoru w Jarosławiu ${ }^{112}$. R. Świętochowski usiłował także ściągnąć do Krakowa część archiwum konwentu Bożego Ciała we Lwowie, które w 1946 r. przypadkowo zostało przewiezione do Poznania. W październiku 1948 r. Jozafat Dawiskiba przesłał z Poznania 25 rękopisów lwowskich, wcielonych do biblioteki rękopisów (uważanej wówczas za odrębną od archiwum) ${ }^{113}$. Jest rzeczą pewną, że oprócz materiałów wytworzonych przez urzędy prowincjalne w Krakowie i Lwowie oraz konwenty w Krakowie, Lwowie, Warszawie (konwent św. Jacka), Jarosławiu, Podkamieniu czy Gidlach, w połowie 1948 r. w archiwum znajdowały się także szczątkowe akta klasztorów w Żninie, Kościanie, Wronkach, Lewinie, Oświęcimiu, Sieradzu, Poznaniu (konwent św. Dominika), Środzie, Opawie, Raciborzu, Opolu i Wrocławiu, kopiariusz dokumentów konwentu płockiego oraz akta klasztorów dominikanek w Poznaniu i Raciborzu. Materiały z wymienionych wyżej placówek we wrześniu 1948 r. wypożyczył bowiem początkujący historyk Jerzy Kłoczowski ${ }^{114}$. W tym samym roku w archiwum przechowywano już tekę

${ }^{109}$ APPD, sygn. Kn 1, Protokół czynności Archiwum Prowincji Polskiej OO. Dominikanów w Krakowie za Prowincjalstwa Przew[ielebnego] O. Dra Bernarda Przybylskiego tom I [rejestr czynności za lata 1947-1955, 1959-1962], s. 6.

${ }^{110}$ APPD, sygn. Kr 842, Kronika Klasztoru krakowskiego OO. Dominikanów przy kościele św. Trójcy od r. 1926, s. 226.

${ }^{111}$ Tamże; APPD, sygn. Kn 17, Korespondencja archiwisty z lat 1868-1956, s. 167 (Poświadczenie o. Łucjana Wołka, 27 VIII 1939 r.); Kamiński, Zarys dziejów, s. 118, przypis 5.

${ }^{112}$ APPD, sygn. Kn 1, Protokół czynności Archiwum Prowincji Polskiej OO. Dominikanów w Krakowie za Prowincjalstwa Przew[ielebnego] O. Dra Bernarda Przybylskiego tom I [rejestr czynności za lata 1947-1955, 1959-1962], s. 6.

${ }_{113}$ Tamże, s. 10.

${ }^{114}$ Tamże, s. 9, 21. 
z aktami dotyczącymi dziejów klasztoru dominikanów w Lublinie ${ }^{115}$. R. Świętochowski wspominał ponadto o księdze uchwał klasztoru dominikanek w Piotrkowie, będącej jedyną jednostką $\mathrm{w}$ archiwum pochodzącą $\mathrm{z}$ tamtejszej placówki ${ }^{116}$. W 1947 r. bez wątpienia istniał już także dział personalny archiwum prowincji, do którego wpływały materiały po zmarłych zakonnikach ${ }^{117}$.

W 1949 r. oficjum archiwisty i bibliotekarza prowincji miał objąć Paweł Kielar ${ }^{118}$. Pracę uniemożliwiło mu jednak aresztowanie za działalność duszpasterską wśród młodzieży. Przez pewien czas zastępował go Świętochowski, wskazany jako archiwista prowincji przez kapitułę prowincjalną obradującą w maju $1950 \mathrm{r}$. na warszawskim Służewie ${ }^{119}$. Kielar opuścił więzienie dopiero po dwóch latach i energicznie zabrał się do pracy. W 1951 r. pisał:

Archiwum przedstawiało się dosyć opłakanie. Dla niektórych kodeksów (może nawet dla większości kodeksów) były już wypełnione kartki inwentarzowe, ale kodeksy nie miały jeszcze numeracji ani też kartki, ponadto akta poszczególnych klasztorów z woj. krakowskiego nie były na [jednym - M.S.] miejscu lecz porozrzucane, akta lwowskie w pakach, a częściowo na stole. Całe sterty różnych papierów walały się wszędzie. Zachęcająco to nie wyglądało ${ }^{120}$.

${ }^{115}$ Tamże, s. 8.

116 Tamże, s. 11.

117 Tamże, s. 5.

${ }_{118}$ Paweł (z chrztu Władysław) Kielar (1912-1972), wstąpił do Zakonu Kaznodziejskiego w 1929 r., a święcenia kapłańskie przyjął w 1938 r. Studiował w Krakowie, Lwowie, Warszawie, Poznaniu i Lublinie; doktorat z historii uzyskał w 1953 r. Początkowo był wikariuszem parafii w Podkamieniu (1938-1941) i subprzeorem we Lwowie, gdzie zaangażował się także w tajne nauczanie i działalność harcerską (1941-1946). Następnie pracował duszpastersko w Krakowie (1946) i Poznaniu (1946-1947) oraz wykładał w Studium Dominikanów w Krakowie (1947-1949). Z powodu kontynuowania pracy wśród młodzieży, został skazany w stalinowskim procesie i osadzony w więzieniu w Katowicach (1949-1951). Po powrocie do Krakowa był m.in. archiwistą i bibliotekarzem prowincji (1951-1959), kierownikiem i zastępcą kierownika tzw. duszpasterstwa tatrzańskiego na Wiktorówkach (1958-1967), bibliotekarzem Studium Generalnego (od 1959), prowincjalnym promotorem Referatu Archiwum i Bibliotek (od 1959), prowincjalnym promotorem beatyfikacji i kanonizacji, subprzeorem konwentu, socjuszem i wikariuszem prowincjała Jana Janczaka (19621966) oraz wiceregensem (1964-1967) i wykładowcą Studium Dominikanów. Pozostawił po sobie kilkadziesiąt prac z zakresu historii dominikanów na ziemiach polskich, głównie w średniowieczu i okresie reformacji. Zob. m.in.: Z. Mazur, Kielar Paweł Władysław, SPTK, t. 6, red. L. Grzebien, Warszawa 1983, s. 64-67; M. Miławicki, Dominikański gazda na Wiktorówkach. O. Pawet Kielar i duszpasterstwo tatrzańskie w latach 1958-1967, w: Komunistyczny aparat represji wobec Polskiej Prowincji Dominikanów, red. M. Miławicki, M. Wenklar, Kraków 2015 (Kościół w okowach), s. 330-396; Szymborski, Krakowscy dominikanie, s. 322-338.

${ }^{119}$ APPD, sygn. S 44/10b, Acta Capitulorum Provinciae Poloniae Ordinis Praedicatorum, t. 4: ab anno 1801-1863 et ab anno 1920-1978, oprac. R.F. Madura, k. 342.

${ }^{120}$ APPD, sygn. Kn 1, Protokół czynności Archiwum Prowincji Polskiej OO. Dominikanów w Krakowie za Prowincjalstwa Przew[ielebnego] O. Dra Bernarda Przybylskiego tom I [rejestr czynności za lata 1947-1955, 1959-1962], s. 16. 
Dzięki pomocy dominikańskich kleryków, przede wszystkim Krzysztofa Kasznicy i Andrzeja Płachty, od sierpnia do 17 października 1951 r. przejrzano całe archiwum, wstępnie posegregowano akta i ułożono na półkach, zaopatrzonych w napisy z nazwami poszczególnych klasztorów. P. Kielar oceniał:

Chyba nigdy dotąd nie było archiwum tak dobrze uporządkowane, aczkolwiek stan dzisiejszy jest jeszcze niewystarczający. Trzeba uporządkować działy wewnątrz nich, zabezpieczyć luźne lotne akty, zinwentaryzować, zaopatrzyć w numerację. Praca posuwa się powoli nadal. Uporządkowano częściowo akta krakowskie, inne akta pomieszczono w pudłach, zmieniono częściowo rozmieszczenie, skontrolowano poszczególne działy. Obecnie Archiwum jest czynne ${ }^{121}$.

W liście do R. Świętochowskiego z 1956 lub 1957 r. P. Kielar opisywał swemu poprzednikowi stan prac $\mathrm{w}$ archiwum:

Uporządkowałem trochę archiwum w tym sensie, że posprzątałem i pozamiatałem, by miało jakiś wygląd. Sygnatur stałych jeszcze nie daję, to nie takie proste rzeczy $(. .$.$) . Na razie wystarcza sygnatura robocza, jaką Ojciec dał { }^{122}$.

P. Kielar w latach 50. XX w. wyłączył z bibliotek studium i konwentu krakowskiego zbiór rękopisów, zwanych odtąd rękopisami bibliotecznymi. Zdaniem Świętochowskiego, Kielarowi udało się zinwentaryzować ponad 750 tytułów ${ }^{123}$. W 1959 r. Florian Szczygieł wydał katalog spuścizny J. Woronieckiego ze zbiorów archiwum, według ówczesnego układu jednostek i (obecnie nieaktualnych) sygnatur ${ }^{124}$. W tym samym roku P. Kielar został promotorem Referatu Archiwum i Bibliotek Prowincji, utworzonego przy Urzędzie Prowincjalnym. Jego zadaniem miał być nadzór nad archiwum prowincji oraz bibliotekami w całej prowincji, w tym klasztornymi ${ }^{125}$. Prowincjał Edmund Sochacki polecił współbratu utworzenie w archiwum działu fotografii i mikrofilmów materiałów dominikańskich, znajdujących się w archiwach państwowych i kościelnych. P. Kielar miał również opracować projekt układu akt kancelarii Urzędu Prowincjalnego, dzięki któremu dokumenty powstałe $\mathrm{w}$ wyniku jego działalności trafiałyby do archiwum już w określonym porządku ${ }^{126}$. W spuściźnie zakonnika zachowały się szkice różnych

${ }^{121}$ Tamże.

${ }^{122}$ APPD, sygn. Kn 17, Korespondencja archiwisty z lat 1868-1956, s. 619 (list o. Pawła Kielara do o. Roberta Świętochowskiego z ok. 1956/1957 r.).

${ }^{123}$ Świętochowski, Biblioteka oo. Dominikanów, s. 310.

${ }^{124}$ F. Szczygieł, Informacje o zbiorze materiałów archiwalnych o. Jacka Woronieckiego OP, „Roczniki Teologiczno-Kanoniczne”, 6 (1959) z. 1-2, s. 89-98.

${ }^{125}$ BDKr, bez sygn., Projekt uchwał dla Konsilium Prowincji w dniu 18.2.1959 r. w sprawie archiwum i bibliotek prowincji, k. nlb.; APPD, sygn. S 1/1, Dokumenty osobiste O. Pawła Kielara ur. 30.10.1912 r. w Krościenku Wyżnym, † 2.1.1972 r. w Krakowie, s. 459 (pismo prowincjała o. Edmunda Sochackiego do o. Pawła Kielara, 1 VII 1959 r.).

${ }^{126}$ BDKr, bez sygn., Projekt uchwał dla Konsilium Prowincji w dniu 18.2.1959 r. w sprawie archiwum i bibliotek prowincji, k. nlb. 
wersji wspomnianego schematu ${ }^{127}$. Jak argumentował, wdrożenie swoistej „instrukcji kancelaryjnej” Urzędu Prowincjalnego mogłoby przyczynić się do nadania jednostkom stałych sygnatur, w miejsce obecnych, tymczasowych ${ }^{128}$.

P. Kielar współpracował z R. Świętochowskim w zakresie opracowania materiałów archiwalnych i bibliotecznych oraz udostępniania ich badaczom. W liście do swego poprzednika z 1953 r. pisał:

Inni za nic nas mają, więc my sami powinniśmy się popierać, byśmy mogli się wreszcie czym popisać. (...) Ja głoszę, że uporządkowałeś arch[iwum] jak od 700 lat nie było, ty więc popieraj bibliotekę ${ }^{129}$.

P. Kielar przesyłał do R. Świętochowskiego wiele pism od studentów i historyków, kierowanych do archiwum z prośbą o udzielenie informacji na temat zbiorów. W styczniu 1952 r. drugi z dominikanów wypożyczył całe archiwum gidelskie w celu jego opracowania oraz stworzenia inwentarza; w 1960 r. zwrócił uporządkowany zespół ${ }^{130}$. W 1956 r. R. Świętochowski w czasie trzymiesięcznego pobytu w Krakowie zinwentaryzował zespół klasztoru krakowskiego (788 jednostek archiwalnych) oraz ułożył alfabetycznie pierwszą półkę działu „Archiwa ojców i braci"131. Kapituła prowincjalna w Poznaniu w 1958 r. zobowiązała prowincjała, by wyznaczył bibliotekarzowi Studium Generalnego w Krakowie pomocników do pracy w bibliotece, ale także $\mathrm{w}$ archiwum prowincji ${ }^{132}$. Być może miało to wpływ na powrót R. Świętochowskiego 1 września 1959 r. na stałe do Krakowa, gdzie od tej pory wspomagał P. Kielara ${ }^{133}$.

W 1961 r. R. Świętochowski ponownie objął oficjum archiwisty prowincji. Jego pomocnikami zostali w 1966 r. Zygmunt Bruno Mazur, a od ok. 1969 r. - Józef Pociecha ${ }^{134}$. R. Świętochowski - tak jak w poprzednich latach - łączył porządkowanie i inwentaryzację źródeł z intensywną pracą naukową. Jak wspominał Jan Góra, ekscentryczny dominikanin

całe noce spędzał w kurzu archiwalnym, wśród papierów dawną ręką zapisanych, wśród osób dawno umarłych. (...) Duchy z dawnych klasztorów,

${ }^{127}$ APPD, sygn. S 1/6, Memoriał do Konsilium Prowincji w sprawie bibliotek oraz uwagi o archiwum i kancelarii prowincjalskiej, s. 67-91.

${ }^{128}$ Tamże, s. 71.

${ }^{129}$ APPD, sygn. Kn 17, Korespondencja archiwisty z lat 1868-1956, s. 619 (list o. Pawła Kielara do o. Roberta Świętochowskiego z ok. 1956/1957 r.).

${ }^{130}$ APPD, sygn. Kn 1, Protokół czynności Archiwum Prowincji Polskiej OO. Dominikanów w Krakowie za Prowincjalstwa Przew. O. Dra Bernarda Przybylskiego, tom I, s. 16-17.

${ }^{131}$ APPD, sygn. Kn 20, Korespondencja archiwisty z lat 1963-1965, s. 143 (pismo ks. Bolesława Kumora do o. Roberta Świętochowskiego, 23 IX 1963 r.); APPD, sygn. Kn 21, Korespondencja archiwisty z lat 1966-1968, s. 89 (R. Świętochowski, Sprawozdanie z prac w Archiwum OO. Dominikanów w Krakowie z lat 1960-1965, 21 II 1966 r.).

${ }^{132}$ APPD, sygn. S 44/10b, Acta Capitulorum Provinciae Poloniae Ordinis Praedicatorum, t. 4: ab anno 1801-1863 et ab anno 1920-1978, oprac. R.F. Madura, k. 387.

${ }^{133}$ APPD, sygn. Kn 1, Protokół czynności Archiwum Prowincji Polskiej OO. Dominikanów w Krakowie za Prowincjalstwa Przew. O. Dra Bernarda Przybylskiego, tom I, s. 21.

${ }^{134}$ APPD, sygn. S 44/10b, Acta Capitulorum Provinciae Poloniae Ordinis Praedicatorum, t. 4: ab anno 1801-1863 et ab anno 1920-1978, oprac. R.F. Madura, k. 406, 442. 
z którymi całymi nocami rozprawiał, były jego towarzyszami. Na jawie i we śnie. Kłopotał się razem z nimi i za nich. Martwił się, skąd weźmie przeor na utrzymanie kapeli w Gidlach i Borku Starym, czy wystarczy na sprowadzenie książek z zagranicy albo na zapłacenie malarzowi Dolabelli. To nic, że sprawy te były sprzed wieków i dawno już zostały załatwione. Zajmował się nimi, jakby to były sprawy dzisiejsze, przejmował się nimi, jakby były jego własne, rozumiał je lepiej, niż ktokolwiek inny ${ }^{135}$.

W jednym z listów R. Świętochowski z humorem porównywał swoje ,ppanowanie" w archiwum z absolutną władzą papieża w Kościele katolickim ${ }^{136}$. Źródła - jak już wspomniano - czytał nocą, nieustannie paląc papierosy, co prawdopodobnie tłumaczy niewielkie ślady przypaleń na niektórych dokumentach. Wiele pracy włożył w kontynuowanie kartoteki biograficznej dominikanów polskich, która w 1971 r. liczyła ok. 40.000 kartek; fiszki wypożyczał użytkownikom, także na zewnątrz ${ }^{137}$.

Wiadomo, że ok. 1971 r. w archiwum znajdowało się łącznie 37 regałów; instytucja posiadała ponadto urządzenia do mikrofilmowania ${ }^{138}$. R. Świętochowski - jak sam przyznawał - w swej pracy skupił się na dwóch obszarach: inwentaryzacji materiałów archiwalnych oraz uzupełnianiu braków za pomocą mikrofilmów i fotokopii ${ }^{139}$. Według szacunków Z. Mazura, dominikanin zinwentaryzował wstępnie ok. 2/3 akt archiwalnych ${ }^{140}$. R. Świętochowski sam przyznawał, że z archiwistyki świeckiej zaczerpnął jedynie zasadę proweniencji, ponadto stosował autorski, „odrębny sposób inwentaryzowania wyderkafów, który polega na śledzeniu historii zapisu od nadania aż do jego likwidacji"141. W 1960 r. zakonnik skatalogował: archiwum konwentu gidelskiego, dział „Archiwa ojców i braci” oraz zespoły dominikańskich Urzędów Prowincjalnych: prowincji polskiej oraz galicyjskiej $^{142}$. W sprawozdaniu $\mathrm{z}$ pięciolecia swej pracy $\mathrm{W}$ archiwum $\mathrm{z}$ lutego 1966 r. podał, że archiwum liczy 2.074 jednostek archiwalnych, a dotąd opraco-

${ }^{135}$ J. Góra, Ostatniemu Prusowi, „Tygodnik Powszechny”, (1979) nr 16, s. 4.

${ }^{136}$ APPD, sygn. Kn 22, Korespondencja archiwisty z lat 1969-1971, s. 49 (list o. Roberta Świętochowskiego do Mirosława Perza z 21 II 1969 r.).

${ }^{137}$ APPD, sygn. Kn 22, Korespondencja archiwisty z lat 1969-1971, s. 631 (szkic listu o. Roberta Świętochowskiego do prowincjała o. Rajmunda Koperskiego z 20 II 1971 r.); APPD, sygn. Kn 23, Korespondencja archiwisty z lat 1972-1973, s. 265 (list Andrzeja Jastrzębskiego do o. Roberta Świętochowskiego z 10 II 1973 r.); APPD, sygn. Kn 23, Korespondencja archiwisty z lat 1972-1973, s. 359 (rewers o. Piusa Bosaka z 20 VI 1973 r.).

${ }^{138}$ APPD, sygn. Kn 22, Korespondencja archiwisty z lat 1969-1971, s. 843-845 (kwestionariusz z „Międzynarodowego Rocznika Archiwów”, b. d.).

${ }^{139}$ APPD, sygn. Kn 22, Korespondencja archiwisty z lat 1969-1971, s. 243 (pismo o. Roberta Świętochowskiego do Urzędu Prowincjalskiego OO. Dominikanów w Warszawie i syndyka o. Edmunda Sochackiego z 20 X 1969 r.). Zob. także: Świętochowski, Źródła do dziejów, s. 84.

${ }^{140}$ APPD, sygn. Kn 24, Korespondencja archiwisty z lat 1973-1977, s. 177 (B. Mazur, Sprawozdanie z działalności w Archiwum Prowincji od 1 IV 1974 - 31 XII 1977 r.).

${ }^{141}$ APPD, bez sygn., [R. Świętochowski], Archiwum OO. Dominikanów w Krakowie [mps, wersja nr 1], k. 2.

${ }^{142}$ APPD, sygn. Kn 1, Protokół czynności Archiwum Prowincji Polskiej OO. Dominikanów w Krakowie za Prowincjalstwa Przew. O. Dra Bernarda Przybylskiego, tom I, s. 21. 
wane zostały akta Urzędów Prowincjalnych: prowincji polskiej, prowincji ruskiej i prowincji galicyjskiej, a także zespoły archiwalne klasztorów w: Borku Starym, Gidlach, Lwowie (konwent Bożego Ciała), Podkamieniu, Warszawie (konwent św. Jacka) i Żółkwi. R. Świętochowski w pierwszej połowie lat 60. XX w. uporządkował ponadto zbiory grafiki i dział kartografii, a także ułożył alfabetycznie drugą półkę działu „Archiwa ojców i braci”143. W 1966 r. szacował, że do zinwentaryzowania pozostało mu jeszcze ok. 200 jednostek archiwalnych, a także zbiory fotografii i pocztówek oraz mikrofilmy ${ }^{144}$.

Kapituła prowincjalna w Warszawie w tym samym roku powierzyła R. Świętochowskiemu zadanie uporządkowanie zasobu archiwum według współczesnych wymogów ${ }^{145}$. W grudniu 1967 r. dominikanin stwierdził, że inwentaryzacja zmierza już ku końcowi, a do opracowania pozostał mu przede wszystkim zespół klasztoru w Tarnobrzegu. Równocześnie deklarował:

Po wykonaniu tej pracy zwołuję komisję, mam przedstawić plan logicznego uszeregowania poszczególnych zespołów i jednostek archiwalnych, które dopiero wtedy uzyskają sygnaturę trwałą na miejsce obecnej, tymczasowej ${ }^{146}$.

W styczniu 1969 r. zakonnik szacował, że zbiory kartograficzne liczą ponad 150 jednostek (w tym 35 druków), z których zinwentaryzowano połowę ${ }^{147}$. Klisze i mikrofilmy wówczas nie były jeszcze skatalogowane; te drugie na potrzeby archiwum i użytkowników wykonywał dominikanin Sebastian Michalczewski, a niekiedy także klerycy dominikańscy ${ }^{148}$. Jako prace dla swoich następców R. Świętochowski wskazywał sporządzenie potrójnych indeksów oraz regestów niektórych jednostek $^{149}$. W $1970 \mathrm{r}$. archiwum miało liczyć 3.000 jednostek z tymczasową sygnaturą ${ }^{150}$. Nie wszyscy dominikanie byli jednak zadowoleni z wykonanej dotąd pracy. Przykładowo Adam Studziński przed 750. rocznicą przybycia braci kaznodziejów na ziemie polskie postulował, by „uporządkować archiwum, które-

${ }^{143}$ APPD, sygn. Kn 21, Korespondencja archiwisty z lat 1966-1968, s. 89 (R. Świętochowski, Sprawozdanie z prac w Archiwum OO. Dominikanów w Krakowie z lat 1960-1965, 21 II 1966 r.).

${ }^{144}$ Tamże.

${ }^{145}$ APPD, sygn. S 44/10b, Acta Capitulorum Provinciae Poloniae Ordinis Praedicatorum, t. 4: ab anno 1801-1863 et ab anno 1920-1978, oprac. R.F. Madura, k. 415.

${ }^{146}$ APPD, sygn. Kn 21, Korespondencja archiwisty z lat 1966-1968, s. 619 (list o. Roberta Świętochowskiego do o. Fabiana Madury z 11 XII 1967 r.).

${ }^{147}$ APPD, sygn. Kn 22, Korespondencja archiwisty z lat 1969-1971, s. 21-23 (R. Świętochowski, Odpowiedź na ankietę dotyczącą zbiorów kartograficznych, 31 I 1969 r.).

148 Tamże, s. 23 (R. Świętochowski, Odpowiedź na ankietę dotyczącą zbiorów kartograficznych, 31 I 1969 r.), 243 (pismo o. Roberta Świętochowskiego do Urzędu Prowincjalskiego OO. Dominikanów w Warszawie i syndyka o. Edmunda Sochackiego z 20 X 1969 r.), 383 (list o. Roberta Świętochowskiego do o. Michała Mroczkowskiego z 8 III 1970 r.).

${ }^{149}$ APPD, bez sygn., [R. Świętochowski], Archiwum OO. Dominikanów w Krakowie [mps, wersja nr 1], k. 2.

${ }^{150}$ Świętochowski, Źródła do dziejów, s. 84. 
go dzisiejszy stan jest pożałowania godny"151. Kapituła prowincjalna w Krakowie, obradująca na przełomie 1969 i 1970 r., poleciła natomiast przyspieszenie porządkowania starych ksiąg w archiwum i bibliotece ${ }^{152}$.

Proces systematyzacji i katalogowania jednostek został zahamowany w kwietniu 1970 r., kiedy magazyn archiwum poddano remontowi. Pomalowano wówczas ściany, założono instalację elektryczną oraz wyposażenie przeciwpożarowe ${ }^{153}$. Co jednak najważniejsze, Józef Pociecha zamontował nowe regały. Inwestycje w archiwum zostały przeprowadzone na polecenie prowincjała Rajmunda Koperskiego, który miał realizować sugestie definitorium ${ }^{154}$ kapituły prowincjalnej w Krakowie z 1969 r. ${ }^{155}$ Materiały archiwalne będące w stanie porządkowania, $\mathrm{w}$ wyniku remontu zostały przeniesione $\mathrm{w}$ różne miejsca. Co ciekawe, zmiany miały miejsce w czasie miesięcznego pobytu R. Świętochowskiego w Wilnie, bez jego wiedzy i zgody.

Po powrocie z zagranicy, zastałem całe archiwum porozciągane Bóg wie gdzie i w Bibliotece zwały akt. Skończyło się na tym, że ani z Archiwum, ani z Biblioteki rękopisów, ani z Biblioteki inkunabułów nikt od kwietnia nie może korzystaćis

Zakonnik przedstawiał sytuację w archiwum w niezwykle ciemnych barwach, pisząc:

Księgi np. uchwał klasztoru krakowskiego i lwowskiego są niedostępne, ani dla mnie, ani dla stron. Ocalały jedynie Acta provincialia, które były w mojej celi i są do dyspozycji ${ }^{157}$.

Żalił się także, że katalogi archiwum zostały wypożyczone na KUL na czas nieograniczony, bez wystawiania rewersu i sporządzenia ich wykazu ${ }^{158}$.

R. Świętochowski w ramach protestu zaprzestał pracy w archiwum i skupił się na własnej pracy badawczej: wyjeżdżał na długie kwerendy, zbierał materiały oraz pisał artykuły naukowe. Wielokrotnie udawał się do Wilna, gdzie m.in. szukał

${ }^{151}$ APPD, bez sygn., Adam Studziński OP, Sprawa rocznicy 750-lecia zakonu dominikańskiego w Polsce, k. nlb.

${ }^{152}$ APPD, sygn. S 44/10b, Acta Capitulorum Provinciae Poloniae Ordinis Praedicatorum, t. 4: ab anno 1801-1863 et ab anno 1920-1978, oprac. R.F. Madura, k. 449.

${ }^{153}$ APPD, sygn. Kn 23, Korespondencja archiwisty z lat 1972-1973, s. 415 (J. Pociecha, Sprawozdanie z działalności Archiwum Polskiej Prowincji OO. Dominikanów za lata 1970-1973); APPD, sygn. Kn 2, Projekt inwestycji renowacyjnych w Archiwum OO. Dominikanów w Krakowie, [ul.] Stolarska 12, $1970 \mathrm{r}$.

${ }^{154}$ Definitorium kapituły prowincjalnej tworzy grono 4, 6 lub 8 dominikanów, wybranych przez uczestników kapituły w celu podjęcia najważniejszych decyzji, obsadzenia urzędów prowincji oraz sporządzenia akt kapituły.

${ }^{155}$ APPD, sygn. Kn 23, Korespondencja archiwisty z lat 1972-1973, s. 415 (J. Pociecha, Sprawozdanie z działalności Archiwum Polskiej Prowincji OO. Dominikanów za lata 1970-1973).

${ }^{156}$ APPD, sygn. Kn 22, Korespondencja archiwisty z lat 1969-1971, s. 457 (pismo o. Roberta Świętochowskiego do o. Rajmunda Koperskiego z 18 VI 1970 r.).

${ }^{157}$ Tamże, s. 459 (list o. Roberta Świętochowskiego do Krystyny Zawadzkiej z 18 VI 1970 r.).

${ }_{158}$ Tamże, s. 629 (szkic pisma o. Roberta Świętochowskiego do prowincjała o. Rajmunda Koperskiego z 20 II 1971 r.). 
źródeł do badań nad historią dominikanów prowincji litewskiej. Od tej pory obowiązki archiwisty de facto wypełniał Józef Pociecha; z czasem R. Świętochowski zaczą jednak udzielać pomocy zwracającym się do niego historykom, a w $1972 \mathrm{r}$. współbrat Anzelm Jezierski gratulował mu powrotu do archiwum ${ }^{159}$. Władze prowincjalne najwyraźniej zaakceptowały jednak, że faktyczne rządy w archiwum od 1970 r. sprawował J. Pociecha, skoro to jego definitorium kapituły prowincjalnej w Poznaniu prosiło w 1973 r. o złożenie sprawozdania z ostatnich lat pracy.

Już w latach 60. XX w. R. Świętochowski planował wydanie inwentarza w czasopiśmie „Archiwa, Biblioteki i Muzea Kościelne”, do czego zachęcał go ks. Bolesław Kumor ${ }^{160}$. Publikację w lubelskim półroczniku miał obiecywać także ks. Stanisław Librowski ${ }^{161}$. Zakonnik pragnął dzięki temu przekształcić archiwum w ważny ośrodek naukowy; przewidywał bowiem, że publikacja katalogu umożliwi upowszechnienie wiedzy o dominikańskich źródłach historycznych, a tym samym nowe badania i publikacje ${ }^{162}$. Kapituła prowincjalna w Warszawie w 1966 r. poleciła R. Świętochowskiemu szybkie ukończenie inwentarza ${ }^{163}$. W grudniu następnego roku zakonnik deklarował, że katalog jest już przez niego przygotowywany do druku, co najpewniej było pewnym stwierdzeniem na wyrost $^{164}$. W następnych miesiącach i latach dominikanin przekonywał, że inwentaryzacja kończy się, a publikacja katalogu nastąpi wkrótce. Na początku kwietnia 1968 r. R. Świętochowski otrzymał formalne pozwolenie od prowincjała Krzysztofa Kasznicy na ogłoszenie go drukiem. Inwentarz miał objąć nie tylko archiwum dominikanów w Krakowie, ale także dominikanek z krakowskiego Gródka oraz z klasztoru w Świętej Annie k. Przyrowa ${ }^{165}$. We wstępie zakonnik planował przedstawienie historii archiwistyki dominikańskiej w Polsce oraz specyfiki dominikańskich archiwaliów ${ }^{166}$. W październiku 1969 r. Świętochowski szacował,

${ }^{159}$ APPD, sygn. Kn 23, Korespondencja archiwisty z lat 1972-1973, s. 223 (list o. Anzelma Jezierskiego do o. Roberta Świętochowskiego z 1972 r.).

${ }^{160}$ APPD, sygn. Kn 21, Korespondencja archiwisty z lat 1966-1968, s. 619 (list o. Roberta Świętochowskiego do o. Fabiana Madury z 11 XII 1967 r.); APPD, sygn. Kn 19, Korespondencja archiwisty z lat 1957-1962, s. 771 (list ks. Bolesława Kumora do o. Roberta Świętochowskiego z 4 X 1962 r.). Zob. także: APPD, sygn. Kn 21, Korespondencja archiwisty z lat 1966-1968, s. 675 (list o. Roberta Świętochowskiego do ks. Tadeusza Miazgi z 6 I 1968 r.).

${ }^{161}$ APPD, sygn. Kn 22, Korespondencja archiwisty z lat 1969-1971, s. 77 (pismo o. Roberta Świętochowskiego do Akademii Teologii Katolickiej w Warszawie z 31 V 1969 r.).

${ }^{162}$ APPD, sygn. Kn 19, Korespondencja archiwisty z lat 1957-1962, s. 243 (pismo o. Roberta Świętochowskiego do Urzędu Prowincjalskiego OO. Dominikanów w Warszawie i syndyka o. Edmunda Sochackiego z 20 X 1969 r.), 771 (list ks. Bolesława Kumora do o. Roberta Świętochowskiego z 4 X 1962 r.).

${ }^{163}$ APPD, sygn. S 44/10b, Acta Capitulorum Provinciae Poloniae Ordinis Praedicatorum, t. 4: ab anno 1801-1863 et ab anno 1920-1978, oprac. R.F. Madura, k. 415.

${ }^{164}$ APPD, sygn. Kn 21, Korespondencja archiwisty z lat 1966-1968, s. 625 (list o. Roberta Świętochowskiego do Anny Nikliborc z 11 XII 1967 r.).

${ }^{165}$ Tamże, s. $751-752$ (list o. Roberta Świętochowskiego do Matki Agnieszki ze Świętej Anny z 23 IV 1968 r.).

${ }^{166}$ APPD, bez sygn., [R. Świętochowski], Archiwum OO. Dominikanów w Krakowie [mps, wersja nr 2], k. 2. 
że ewentualne przygotowanie maszynopisu inwentarza do druku zajęłoby ok. 4 miesiące pracy ${ }^{167}$. Inwentarz jednak nigdy nie ukazał się drukiem. Zapewne miał na to wpływ remont magazynu w $1970 \mathrm{r}$. i wiążące się z nim zniechęcenie dominikanina, a być może także wypożyczenie katalogów na KUL. Prawdopodobnie ok. 1972 r. Świętochowski powrócił do pomysłu publikacji spisu wszystkich jednostek; rok później stwierdził bowiem, że pozbawiono go oficjum archiwisty „w przeddzień ogłoszenia drukiem Inwentarza Archiwum"168. W 1973 r. zakonnik planował ponadto publikację wykazu rękopisów kapeli gidelskiej w kwartalniku „Muzyka”, co jednak nie doszło do skutku ${ }^{169}$. Drukiem ukazały się za to inne inwentarze: w 1962 r. Maria Prokopowicz w katalogu rękopisów muzycznych zmikrofilmowanych przez Bibliotekę Narodową zamieściła opis 18 jednostek - głównie antyfonarzy, graduałów i mszałów - będących wówczas jeszcze w zbiorach Biblioteki Kolegium Filozoficzno-Teologicznego Dominikanów w Krakowie ${ }^{170}$. We wspomnianej instytucji przechowywano również 25 średniowiecznych, łacińskich rękopisów bibliotecznych z zakresu filozofii i teologii, których inwentarz w jęz. francuskim opublikowała w 1970 r. Zofia Włodek ${ }^{171}$.

R. Świętochowski dążył do zgromadzenia wszystkich informacji, mikrofilmów, fotokopii i odpisów akt (po)dominikańskich $\mathrm{z}$ terenu dawnych prowincji polskiej, litewskiej i ruskiej. W tym celu odwiedzał lub kontaktował się z archiwami państwowymi i kościelnymi w całym kraju, jak również z Archiwum Generalnym Zakonu Kaznodziejskiego w Rzymie. W ostatnim przypadku szczególną pomoc w pozyskaniu materiałów okazał Fabian Madura ${ }^{172}$. R. Świętochowski zaangażował lub korzystał z pomocy zarówno współbraci-badaczy (Pawła Kielara, Zygmunta Bruno Mazura), jak również zakonników bez wykształcenia historycznego (np. Adama Studzińskiego, Mieczysława Alberta Krąpca, Honoriusza Kowalczyka) oraz sióstr zakonnych. Fotokopie i mikrofilmy miały zostać uwzględnione w wydanym drukiem inwentarzu. Ich zbieranie wyrażało dążenie R. Świętochowskiego do „stworzenia archiwum specjalnego, idealnego"173.

${ }^{167}$ APPD, sygn. Kn 22, Korespondencja archiwisty z lat 1969-1971, s. 243 (pismo o. Roberta Świętochowskiego do Urzędu Prowincjalskiego OO. Dominikanów w Warszawie i syndyka o. Edmunda Sochackiego z 20 X 1969 r.).

${ }^{168}$ APPD, sygn. Kn 23, Korespondencja archiwisty z lat 1972-1973, s. 419 (pismo definitorium kapituły prowincjalnej Polskiej Prowincji Dominikanów w Poznaniu do o. Roberta Świętochowskiego z 20 XII 1973 r.).

${ }^{169}$ Tamże, s. 395 (pismo Elżbiety Dziębowskiej do o. Roberta Świętochowskiego z 18 X 1973 r.).

${ }^{170}$ Katalog mikrofilmów muzycznych, II, oprac. M. Prokopowicz, Warszawa 1962 (Biblioteka Narodowa, Katalog mikrofilmów, nr 9), s. 89-91.

${ }^{171}$ Z. Włodek, Inventaire des manuscrits médiévaux latins, philosophiques et théologiques de la Bibliothèque des Pères Dominicains de Cracovie, „Mediaevalia Philosophica Polonorum”, 14 (1970) s. 155-186.

172 Owocem kwerend R. Madury w Rzymie stał się m.in. jego artykuł Polonika w Archiwum Gtównym Zakonu OO. Dominikanów w Rzymie, „Archiwa, Biblioteki i Muzea Kościelne”, 37 (1978) s. 297-307. Autor zaznaczył, że wiele mikrofilmów, fotokopii i regestów wspomnianych poloników dominikańskich znajduje się obecnie w Archiwum Polskiej Prowincji Dominikanów w Krakowie.

${ }^{173}$ APPD, bez sygn., [R. Świętochowski, Fragment wystąpienia na temat Archiwum Polskiej Prowincji Dominikanów i znajdujących się w nim źródeł do historii nowożytnej polskich dominikanów], k. nlb. 
W czasie kadencji R. Świętochowskiego zasób archiwum został wzbogacony o liczne materiały. Przykładowo zakonnik miał odbyć kilka podróży do Lublina, gdzie na strychach znalazł tyle archiwaliów, że zespół klasztoru przy ul. Złotej rozrósł się z 1 do 92 zinwentaryzowanych jednostek, w zdecydowanej większości XIX-wiecznych akt ${ }^{174}$. Z kolei wielki dobroczyńca instytucji, prowincjał Krzysztof Kasznica w 1968 r. z powodzeniem zwrócił się do Kurii Biskupiej we Włocławku z prośbą o przekazanie do Krakowa 20 ksiąg podominikańskich, przechowywanych w tamtejszym archiwum diecezjalnym ${ }^{175}$. W kwietniu $1970 \mathrm{r}$. R. Świętochowski przebywał przez miesiąc w Wilnie, gdzie w Oddziale Rękopisów Biblioteki Narodowej Wileńskiego Uniwersytetu Państwowego zdobył materiały historyczne do historii prowincji litewskiej oraz nawiązał kontakty w celu wzajemnej wymiany mikrofilmów ${ }^{176}$. W następnych latach miały miejsce kolejne wizyty R. Świętochowskiego we wspomnianym mieście. Równocześnie dominikanin przekazywał instytucjom i osobom prywatnym materiały archiwalne, które nie pasowały do profilu kierowanej przez niego placówki.

Zakonnik podejmował także pewne starania związane $\mathrm{z}$ konserwacją materiałów archiwalnych. Współpracował w tym zakresie z Ireną Marią Laskowską, która twierdziła, że dzięki niej wiele obiektów zostało „zakonserwowanych i tym samym uratowanych od zniszczenia" 177 .

R. Świętochowski był zwolennikiem szerokiego udostępniania zasobu badaczom. Przyjmował ich popołudniami w swojej zakonnej celi obok magazynów, „zawalonej papierami i archiwaliami, pełnej twórczego niepokoju i nieporządku"178. Źródła archiwalne początkowo wypożyczał także na zewnątrz, czego zakazała dopiero kapituła prowincjalna w Krakowie, obradująca na przełomie 1969 i 1970 r. ${ }^{179}$ Rok wcześniej R. Świętochowski wyznał:

Jako archiwista od szeregu lat staram się, aby z naszych zbiorów jak najwięcej korzystano. Zapamiętałem sobie powiedzenie ks. prof. Librowskiego, że archiwum to nie magazyn uporządkowanych dokumentów, lecz urząd, który sumiennie obsługuje strony i jest doradcą uczonych. Miałem kilka wypadków, że po rozmowie ze mną zmieniano tematy prac dyplomowych, choć tematy

${ }^{174}$ APPD, sygn. Kn 22, Korespondencja archiwisty z lat 1969-1971, s. 808 (list o. Roberta Świętochowskiego do o. Ignacego Góry z 21 XII 1971 r.).

${ }^{175}$ APPD, sygn. Kn 21, Korespondencja archiwisty z lat 1966-1968, s. 687 (szkic niewysłanego listu o. Krzysztofa Kasznicy do Kurii Biskupiej we Włocławku z 14 I 1968 r.), 857 (szkic listu o. Krzysztofa Kasznicy do prowincjała oo. bazylianów w Warszawie z 1968 r.).

${ }^{176}$ APPD, sygn. Kn 22, Korespondencja archiwisty z lat 1969-1971, s. 323 (list o. Roberta Świętochowskiego do o. Jacka Bojarskiego z 21 I 1970 r.), 445 (list o. Roberta Świętochowskiego do Anny Żaboklickiej-Wąsowiczowej z 6 VI 1970 r.), 471 (pismo o. Roberta Świętochowskiego do Jurgisa Tornau z 6 VI 1970 r.).

${ }^{177}$ APPD, sygn. Kn 23, Korespondencja archiwisty z lat 1972-1973, s. 155 (list Ireny Marii Laskowskiej do o. Roberta Świętochowskiego z 3 VII 1972 r.). Zob. także: Tamże, s. 153 (pismo o. Roberta Świętochowskiego do Ireny Marii Laskowskiej z 30 VI 1972 r.).

${ }^{178}$ Góra, Ostatniemu Prusowi, s. 4.

${ }^{179}$ APPD, sygn. S 44/10b, Acta Capitulorum Provinciae Poloniae Ordinis Praedicatorum, t. 4: ab anno 1801-1863 et ab anno 1920-1978, oprac. R.F. Madura, k. 449. Zakaz utrzymała w mocy kolejna kapituła prowincjalna w Poznaniu (1973), zob.: tamże, k. 481. 
poprzednie już były zatwierdzone w Ministerstwie. Kilka tematów podjęto na skutek moich sugestii. Osoby, którym udostępniałem archiwalia z kolei odwdzięczały się tu i ówdzie podziękowaniem w swoich publikacjach ${ }^{180}$.

W 1973 r. kapituła prowincjalna w Poznaniu wyznaczyła na oficjum archiwisty prowincji Zygmunta Bruno Mazura, który swoje obowiązki objął 1 kwietnia 1974 r. ${ }^{181}$ Bracia kapitulariusze polecili mu, by warunki pracy w archiwum zostały przystosowane do współczesnych wymagań ${ }^{182}$. Zakonnik szybko podjął się usystematyzowania swej działalności: przez pierwsze lata skrupulatnie odnotowywał prowadzone prace, prowadził statystyki, składał przełożonym regularne sprawozdania oraz wprowadził liczbę dziennika w bieżącej korespondencji archiwum. Niemal natychmiast po objęciu urzędu podjął także starania o poprawę infrastruktury archiwum. W 1976 r. prowincjał Michał Mroczkowski doprowadził do zainstalowania centralnego ogrzewania w magazynie, dzięki czemu stało się możliwe unikanie większych wahań temperatury ${ }^{183}$. Rok później Z. Mazur zaznaczył jednak, że należy już myśleć o większym pomieszczeniu, gdyż na półkach pozostało niewiele miejsca $i$ wystarczy go najwyżej na dwa lata ${ }^{184}$. W okresie pomiędzy 1974 a 1975 r. - dzięki pomocy przeora krakowskiego Walentego Potworowskiego - archiwum otrzymało pomieszczenie na swą pierwszą pracownię, mieszczącą się w dawnej celi R. Świętochowskiego. Kuria prowincjalna pokryła koszty zakupu regałów, biurek i lamp; ponadto - w wyniku starań prowincjała M. Mroczkowskiego - do pracowni trafiły czytnik i aparat do mikrofilmowania. Wtedy też założono bibliotekę podręczną archiwum ${ }^{185}$. W kolejnych latach Mazur narzekał jednak na ciasnotę w pracowni: „nie ma w niej miejsca ani na odpo-

${ }^{180}$ APPD, sygn. Kn 22, Korespondencja archiwisty z lat 1969-1971, s. 77-78 (pismo o. Roberta Świętochowskiego do Akademii Teologii Katolickiej w Warszawie, 31 V 1969 r.).

${ }^{181}$ APPD, sygn. S 44/10b, Acta Capitulorum Provinciae Poloniae Ordinis Praedicatorum, t. 4: ab anno 1801-1863 et ab anno 1920-1978, oprac. R.F. Madura, k. 474; APPD, sygn. Kn 24, Korespondencja archiwisty z lat 1973-1977, s. 177 (B. Mazur, Sprawozdanie z działalności w Archiwum Prowincji od 1 IV 1974 - 31 XII 1977 r.). Bruno (z chrztu Zygmunt) Mazur (1931-2000) wstąpił do Zakonu Kaznodziejskiego w 1948 r., a święcenia kapłańskie przyjął w 1957 r. Studiował w Krakowie i Wrocławiu; doktorat z historii uzyskał w 1972 r. W tym samym roku zamieszkał w Krakowie, gdzie pracował jako wykładowca (1972-1990) i regens (1979-2000) Kolegium Dominikanów, archiwista prowincji (1973-1994, 1998-2000), prowincjalny promotor beatyfikacji i kanonizacji oraz postulator w procesie beatyfikacyjnym Michała Czartoryskiego. Pozostawił po sobie kilkadziesiąt prac z zakresu historii polskich dominikanów. Zob. m.in.: C.J. Wichrowicz, Mazur Bruno Zygmunt, SPTK, t. 9, red. J. Mandziuk, Warszawa 2006, s. 405-406.

${ }^{182}$ APPD, sygn. S 44/10b, Acta Capitulorum Provinciae Poloniae Ordinis Praedicatorum, t. 4: ab anno 1801-1863 et ab anno 1920-1978, oprac. R.F. Madura, k. 481.

${ }^{183}$ APPD, sygn. Kn 24, Korespondencja archiwisty z lat 1973-1977, s. 315 (B. Mazur, Sprawozdanie z działalności w Archiwum Prowincji od 1 I 1976 - 31 XII 1976 r.).

${ }^{184}$ Tamże, s. 533 (B. Mazur, Sprawozdanie z działalności w Archiwum Prowincji od 1 I 1977 31 XII 1977 r.), 544 (B. Mazur, Sprawozdanie z działalności w Archiwum Prowincji od 1 IV 1974 31 XII 1977 r.).

185 Tamże, s. 177 (B. Mazur, Sprawozdanie z działalności w Archiwum Prowincji od 1 IV 1974 - 31 XII 1977 r.), 542 (B. Mazur, Sprawozdanie z działalności w Archiwum Prowincji od 1 IV 1974 - 31 XII 1977 r.). 
wiedni stół, ani na niezbędne przy segregacji regały. W tych warunkach nie ma też możliwości zatrudnienia na stałe jakiegoś świeckiego pracownika"186. Pisał również: „Skromność pomieszczenia jest wielkim utrudnieniem przy segregacji akt, których w tych warunkach nie ma gdzie rozłożyć"187.

Krótką charakterystykę zasobu archiwum z pierwszych lat pracy Z. Mazura można znaleźć w jednym z numerów miesięcznika „Życie i Myśl”. Publicysta i historyk Romuald Szpor, który w 1977 r. przez kilka dni gościł w klasztorze krakowskim, pisał:

Z zespołu 6000 jednostek archiwalnych, 1500 dotyczy Krakowa, dalej idą według wielkości: archiwalia lwowskie, gidelskie, św. Jacka w Warszawie, jarosławskie, św. Stanisława w Lublinie, tarnopolskie. Z archiwów śląskich zachowały się znikome ilości dokumentów z Wrocławia, Raciborza i Opola. Dokumentów pergaminowych (dyplomów) poczynając od XIII-wiecznych jest tu około tysiąca. (...) W lokalu krakowskiego archiwum mieszczą się także tymczasowo inkunabuły, których jest około stu pięćdziesięciu, oraz to, co cieszy każdego szperacza najbardziej - rękopisy biblioteczne w liczbie około ośmiuset pięćdziesięciu ${ }^{188}$.

Z przytoczonego opisu wynika, że w magazynie archiwum znajdowały się już księgi liturgiczne, a także - obecnie przynależące do zasobu biblioteki - inkunabuły. Archiwum odpowiadało więc (także finansowo) za ich inwentaryzację, udostępnianie oraz konserwację. Dnia 11 maja 1978 r. archiwum zwiedził generał zakonu Vincent de Couesnongle, któremu Z. Mazur zaprezentował wybrane, najcenniejsze księgi i dyplomy pergaminowe ${ }^{189}$.

Następca R. Świętochowskiego kontynuował proces katalogowania materiałów archiwalnych; w 1977 r. zapełnionych było łącznie ok. 5000 kart inwentarzowych $^{190}$. Szczegółowe opisy prowadzonych przez siebie prac Z. Mazur pozostawił w sprawozdaniach za dany rok lub kadencję. Warto jedynie podać przykładowe dane, świadczące o jego pracowitości: w 1977 r. inwentaryzacja objęła łącznie 419 jednostek; najbardziej czasochłonne miało okazać się porządkowanie materiałów Urzędu Prowincjalnego i akt z zespołu klasztoru krakowskiego; ponadto opracowano wiele zespołów dotyczących małych klasztorów ${ }^{191}$. W jednym z listów z lutego 1977 r. Z. Mazur pisał - dość mocno uogólniając - że archiwum jest uporządkowane, a do opracowania pozostały jeszcze materiały drugorzędne, do których zaliczył akta osobowe, parafialne czy folwarczne ${ }^{192}$. Pod koniec tego

${ }^{186}$ Tamże, s. 315 (B. Mazur, Sprawozdanie z działalności w Archiwum Prowincji od 1 I 1976 31 XII 1976 r.).

${ }^{187}$ Tamże, s. 533 (B. Mazur, Sprawozdanie z działalności w Archiwum Prowincji od 1 I 1977 31 XII 1977 r.).

${ }^{188}$ Szpor, Biblioteka i archiwum, s. 54-55.

${ }^{189}$ APPD, sygn. Kr 1397, Kronika Konwentu OO. Dominikanów w Krakowie z lat 1975-1986, s. 226.

${ }^{190}$ APPD, sygn. Kn 24, Korespondencja archiwisty z lat 1973-1977, s. 365 (list o. Bruno Mazura do Krystyny Zawadzkiej z 1 II 1977 r.).

${ }_{191}$ Tamże, s. 533-536 (B. Mazur, Sprawozdanie z działalności w Archiwum Prowincji od 1 I 1977 - 31 XII 1977 r.).

${ }^{192}$ Tamże, s. 365 (list o. Bruno Mazura do Krystyny Zawadzkiej z 1 II 1977 r.). 
samego roku bardziej konkretnie wymienił, że do dalszego opracowania pozostały zespoły: Urzędów Prowincjalnych, prowincji galicyjskiej i prowincji polskiej, klasztoru na warszawskim Służewie, parafii Bożego Ciała we Lwowie, kościoła i konwentu w Gdańsku, kilkanaście teczek nieistniejących klasztorów, jak również akta osobiste ojców i braci ${ }^{193}$.

Z. Mazur planował także opublikowanie inwentarza materiałów archiwalnych oraz katalogu rękopisów bibliotecznych, być może bazując na dotychczasowej pracy R. Świętochowskiego. Romuald Szpor pisał:

Inwentarz archiwalny i katalog rękopisów są już na ukończeniu i można z nich praktycznie korzystać na miejscu. O. dr Bruno Mazur przygotowuje je aktualnie do druku. Gdyby ojcu Robertowi Świętochowskiemu udało się ukończyć dzieło, które ma tak bardzo zaawansowane - katalog wszystkich poświadczonych źródłowo ojców i braci, tak jak zestawiono wszystkich dominikanów posiadających stopnie naukowe i studiujących za granicą - byłby to niemal idealny komplet pomocy dla dalszych studiów nad historią zakonu ${ }^{194}$.

W celu pozyskania nowych nabytków, Z. Mazur wyjeżdżał często poza Kraków. Dzięki temu do archiwum trafiła m.in. znaczna ilość akt z Wielkich Oczu, Jarosławia, Wrocławia, Tarnobrzegu i Gdańska. W latach 1974-1975 dominikanin doprowadził do dostarczenia z warszawskiego Służewa archiwum Studium Prowincji z czasów II Rzeczpospolitej. W 1975 r. dążył z kolei do zgromadzenia brakujących rubrycel zakonnych (głównie z okresu międzywojennego i powojennego) oraz egzemplarzy „Biuletynu Informacyjnego Polskiej Prowincji Dominikanów"195. Pięć lat później Fabian Madura przekazał do archiwum maszynopisy opracowanych przez siebie akt kapituł prowincjalnych ${ }^{196}$.

Trzecie wydanie Statutu Polskiej Prowincji Zakonu Kaznodziejskiego z 1986 r. po raz pierwszy zawierało sformułowanie, że „Dokumenty i manuskrypty oraz korespondencję należy przekazać do archiwum prowincji, chyba że prowincjał zarządzi inaczej”; wcześniejsze wersje akcentowały wolę prowincjała w tym zakresie $^{197}$. Z. Mazur zwracał uwagę, że wiele ważnych dokumentów przełożeni włączają do swoich akt osobowych, przez co można do nich dotrzeć dopiero po śmierci danego zakonnika. Jako przykład niezwykłego znaleziska wymienił od-

${ }^{193}$ Tamże, s. 544 (B. Mazur, Sprawozdanie z działalności w Archiwum Prowincji od 1 IV 1974 - 31 XII 1977 r.).

${ }^{194}$ Szpor, Biblioteka i archiwum, s. 55. Przez zestawienie dominikanów studiujących za granicą autor rozumiał artykuł R. Świętochowskiego i A. Chruszczewskiego Polonia Dominicana apud extraneos, w: Studia nad historia dominikanów w Polsce 1222-1972, t. 2, red. J. Kłoczowski, Warszawa 1975, s. 467-572.

${ }^{195}$ APPD, sygn. Kn 24, Korespondencja archiwisty z lat 1973-1977, s. 95 (list o. Bruno Mazura do o. Szczepana Jaroszewskiego z 28 IV 1975 r.), 101 (list o. Bruno Mazura do o. Wincentego Króla z 4 VI 1975 r.), 105 (list o. Bruno Mazura do o. Kaliksta Suszyły z 4 VI 1975 r.).

${ }^{196}$ Szymborski, Ze Lwowa poprzez Włochy, s. 111.

${ }^{197}$ APPD, bez sygn., Statut Polskiej Prowincji Zakonu Kaznodziejskiego, Warszawa 1986, nr 65. Por. z: APPD, sygn. Pp 36/3, Statutum Provinciae Poloniae Ordinis Praedicatorum, Cracoviae 1970, nr 65; APPD, bez sygn., Statut Polskiej Prowincji Zakonu Kaznodziejskiego, Warszawa 1983, nr 65. 
nalezienie gdańskiej „Liber Consiliorum” w spuściźnie Wojciecha Kobzdeja ${ }^{198}$. Z. Mazur narzekał równocześnie na brak systematycznego napływu dokumentacji z Urzędu Prowincjalnego oraz z poszczególnych klasztorów, ale także na ignorancję przełożonych wspólnot, którzy po śmierci danego zakonnika „według własnego uznania niszczą zachowane materiały lub bez końca przetrzymują"199.

Z. Mazur zapoczątkował proces kompleksowej konserwacji i oprawy materiałów archiwalnych. W listopadzie $1975 \mathrm{r}$. zwrócił się do rady prowincji z prośbą o przyznanie co roku specjalnych środków finansowych na ten cel. Stan rękopisów liturgicznych, akt archiwalnych i inkunabułów określił jako fatalny.

Nigdy nie konserwowane, wymagają one $\mathrm{w}$ wielu wypadkach natychmiastowego zabezpieczenia. Są bowiem często zaatakowane przez pleśń, korniki i pozbawione przez ząb czasu opraw ulegają rozsypce. Udostępnianie ich w takim stanie, często poważnym badaczom nie świadczy najlepiej o naszej odpowiedzialności za powierzone dziedzictwo kulturowe" - argumentowa $2^{200}$.

Sumy przekazywane przez najwyższe władze prowincji, choć wysokie, nie były jednak wystarczające, w związku z czym w $1977 \mathrm{r}$. Z. Mazur po raz pierwszy wystosował prośbę o solidarną pomoc finansową dla archiwum, przesłaną do przeorów lub proboszczów z wszystkich dominikańskich konwentów i domów zakonnych w Polsce ${ }^{201}$. Równocześnie apelował do uczestników zbliżającej się kapituły prowincjalnej, by zobowiązać klasztory do rocznej, jednorazowej zapomogi dla archiwum $^{202}$. Akta kapituły warszawskiej w 1978 r. podają już, że konserwacji poddano wiele dokumentów archiwalnych ${ }^{203}$. Warto dodać, że Z. Mazur zapoczątkował proces oprawiania nowszych akt luźnych (głównie spuścizn) w kodeksy, co uznawał za formę ich ochrony przez zniszczeniem lub zagubieniem.

W oparciu o materiały archiwalne Z. Mazur prowadził liczne badania oraz kwerendy dla innych historyków; pracę w archiwum wykorzystywał także do gromadzenia notatek bibliograficznych ${ }^{204}$. W czasie pełnienia swojego urzędu, $\mathrm{z}$ archiwum w dalszym ciągu żywo współpracował Fabian Madura. W przeciwieństwie do R. Świętochowskiego, Z. Mazur był bardziej ostrożny w udostępnianiu zasobu użytkownikom. Powołując się na decyzje kapituły z przełomu 1969

${ }^{198}$ APPD, sygn. Kn 24, Korespondencja archiwisty z lat 1973-1977, s. 321 (B. Mazur, Sprawozdanie z działalności w Archiwum Prowincji od 1 I 1976 - 31 XII 1976 r.).

${ }^{199}$ Tamże, s. 181 (B. Mazur, Sprawozdanie z działalności w Archiwum Prowincji od 1 I 1976 31 XII 1976 r.), 321 (B. Mazur, Sprawozdanie z działalności w Archiwum Prowincji od 1 I 1976 31 XII 1976 r.).

${ }^{200}$ Tamże, s. 155 (pismo o. Bruno Mazura do Rady Prowincji Polskiej, 18 XI 1975 r.).

${ }^{201}$ Tamże, s. 445 (list o. Bruno Mazura do o. Bolesława Gołębia z 26 VI 1977 r.), 447 (list o. Bruno Mazura do o. Juliusza Żelazko z 26 VI 1977 r.), 449 (list o. Bruno Mazura do o. Szczepana Jaroszewskiego z 14 IX 1977 r.), 485 (list o. Bruno Mazura do o. Leonarda Węgrzyniaka z 14 IX 1977 r.), 487 (list o. Bruno Mazura do o. Januarego Pusza z 14 IX 1977 r.).

${ }^{202}$ Tamże, s. 542 (B. Mazur, Sprawozdanie z działalności w Archiwum Prowincji od 1 IV $1974-31$ XII 1977 r.).

${ }^{203}$ APPD, sygn. S 44/10b, Acta Capitulorum Provinciae Poloniae Ordinis Praedicatorum, t. 4: ab anno 1801-1863 et ab anno 1920-1978, oprac. R.F. Madura, k. 508.

${ }^{204}$ APPD, sygn. Kn 24, Korespondencja archiwisty z lat 1973-1977, s. 365 (list o. Bruno Mazura do Krystyny Zawadzkiej z 1 II 1977 r.). 
i 1970 r., deklarował zaprzestanie wypożyczania źródeł poza archiwum ${ }^{205}$. Zdarzały się jednak wyjątki od tej reguły, a nawet przypadki, że materiały archiwalne wypożyczano do innych klasztorów dominikańskich i tam udostępniano je użytkownikom na miejscu ${ }^{206}$. W $1977 \mathrm{r}$. ustalono stałe godziny urzędowania, w czasie których Z. Mazur poświęcał swój czas użytkownikom ${ }^{207}$. Co ciekawe, począwszy od 1976 r. zakonnik preferował współpracę z badaczami z wyższym wykształceniem. Pisał wówczas:

Ograniczam i niechętnie udostępniam nasze materiały studentom. Znaczny procent dokumentów jest poważnie zniszczonych i w takim stanie korzystanie z archiwaliów wymaga dużej umiejętności, której studenci najczęściej nie posiadają ${ }^{208}$.

Dominikanin całkowicie zaprzestał także udostępniania najnowszych dokumentów.

W latach 80. XX w. w archiwum na pół etatu pracowała s. Laurentyna Wojciechowska OP. Już we wcześniejszej dekadzie Z. Mazur - jako pierwszy archiwista prowincji - zaczął zatrudniać osoby świeckie. Od 1974 do czerwca 1975 r. Matylda Osterwa zinwentaryzowała 89 rękopisów bibliotecznych; w 1976 r. $\mathrm{z}$ powodu braku odpowiedniego pracownika w archiwum musiano jednak zaniechać ich katalogowania ${ }^{209}$. Pomocy w bieżącej działalności archiwum, obsłudze użytkowników lub pracach inwentaryzacyjnych udzielali także współbracia Mazura, w tym Józef Pociecha i Mateusz Bogucki. W latach 1974-1975 ks. Karol Mrowiec porządkował i inwentaryzował muzykalia gidelskie i lwowskie ${ }^{210}$. Rok później udało się zakończyć porządkowanie 18 muzykaliów gidelskich oraz krakowskich $^{211}$. Publikację opracowanego przez Mrowca katalogu muzykaliów gidelskich w 1986 r. uznano za ,pierwszy widomy efekt wieloletnich prac inwentaryzacyjnych" w archiwum ${ }^{212}$. Wspomniany inwentarz miał się ukazać drukiem już ok. 1978 r. w planowanym trzecim tomie Studiów nad historia dominikanów w Polsce, co jednak nie doszło do skutku ${ }^{213}$. Owocem współpracy Mazura ze Ste-

${ }^{205}$ Tamże, s. 11 (list o. Bruno Mazura do Ireny Laskowskiej z 26 IX 1974 r.).

${ }^{206}$ Tamże, s. 217 (list o. Krzysztofa Kasznicy do o. Bruno Mazura z 21 VI 1976 r.).

${ }^{207}$ Tamże, s. 538 (B. Mazur, Sprawozdanie z działalności w Archiwum Prowincji od 1 I 1977 31 XII 1977 r.).

${ }^{208}$ Tamże, s. 323 (B. Mazur, Sprawozdanie z działalności w Archiwum Prowincji od 1 I 1976 31 XII 1976 r.).

${ }^{209}$ Tamże, s. 177-179, 183 (B. Mazur, Sprawozdanie z działalności w Archiwum Prowincji od 1 I 1976 - 31 XII 1976 r.), 319 (B. Mazur, Sprawozdanie z działalności w Archiwum Prowincji od 1 I 1976 - 31 XII 1976 r.).

${ }^{210}$ Tamże, s. 177-179, 183 (B. Mazur, Sprawozdanie z działalności w Archiwum Prowincji od 1 I 1976 - 31 XII 1976 r.).

${ }^{211}$ Tamże, s. 319 (B. Mazur, Sprawozdanie z działalności w Archiwum Prowincji od 1 I 1976 31 XII 1976 r.).

${ }^{212}$ Z. Mazur, Stowo wstępne, w: K. Mrowiec, Katalog muzykaliów gidelskich. Rękopisy muzyczne kapeli klasztoru gidelskiego przechowywane w Archiwum Prowincji Polskiej OO. Dominikanów w Krakowie, Kraków 1986, s. 5.

${ }^{213}$ APPD, sygn. Kn 24, Korespondencja archiwisty z lat 1973-1977, s. 357 (list o. Bruno Mazura do ks. Karola Mrowca z 30 I 1977 r.). 
fanem Gąsiorowskim stał się z kolei Inwentarz archiwum klasztoru dominikanów $w$ Żótkwi, opublikowany w 1994 r. ${ }^{214}$

Od 1 sierpnia 1994 r. oficjum archiwisty prowincji wypełniał Jan Andrzej Spież $\dot{z}^{215}$. Od 1998 r. do śmierci 22 stycznia 2000 r. archiwistą prowincji ponownie był Zygmunt Bruno Mazur, jednak w czasie choroby zastępował go J.A. Spież $^{216}$. W latach 1998-1999 zmikrofilmowano wiele ksiąg metrykalnych z Krakowa, Czortkowa, Lwowa i Podkamienia ${ }^{217}$, a w wakacje 1999 r. główny magazyn archiwum przeszedł remont. Prowincjał Maciej Zięba mianował J.A. Spieża 13 marca 2000 r. p.o. archiwisty prowincji, zaś rada prowincji 28 grudnia tego samego roku przydzieliła mu wspomniany urząd ${ }^{218}$. W $2000 \mathrm{r}$. instytucja otrzymała nowy magazyn przy głównym korytarzu klasztoru, a dwa lata później dodatkową pracownię ${ }^{219}$. W maju $2000 \mathrm{r}$. w magazynach zamontowano także nowe, metalowe regały. J.A. Spież uzupełnił i zmienił układ katalogu dyplomów pergaminowych konwentu krakowskiego, sporządzonego w czasie II wojny światowej przez K. Kaczmarczyka. Opracowany został także katalog pergaminów lwowskich. W 2004 r. J.A. Spież został wybrany przeorem klasztoru na warszawskim Służewie, gdzie też zamieszkał, jednak dalej pełnił urząd archiwisty prowincji. Część prac instytucji koordynował więc od 2004 r. Tomasz Gałuszka, który m.in. zinwentaryzował część nowożytnych rękopisów bibliotecznych ${ }^{220}$. W latach 2005-2011 archiwum wspomagał także Marek Miławicki, najczęściej udostępniając zbiory użytkownikom.

${ }^{214}$ Z. Mazur, S. Gąsiorowski, Inwentarz archiwum klasztoru Dominikanów w Żótkwi, APPD, w: J.T. Petrus, Kościoły i klasztory w Żółkwi, Kraków 1994 (Materiały do dziejów sztuki sakralnej na ziemiach wschodnich dawnej Rzeczypospolitej, cz. 1: Kościoły i klasztory rzymskokatolickie dawnego województwa ruskiego, t. 2), s. 155-163.

215 Jan Andrzej Spież (ur. 1941) wstąpił do Zakonu Kaznodziejskiego w 1966 r. , a święcenia kapłańskie przyjął w 1973 r. Studiował w Poznaniu i Krakowie. Pełnił kolejno obowiązki duszpasterza akademickiego w Poznaniu (1973-1980), pracownika Instytutu Tomistycznego na warszawskim Służewie (1980-1983), przeora i proboszcza parafii na Służewie (1983-1989), duszpasterza akademickiego we Wrocławiu (1989-1993), duszpasterza w Gdańsku (1993-1994), archiwisty prowincji w Krakowie (1994-1998, 2000-2008), przeora (2004-2007), a następnie archiwisty klasztoru na Służewie. Był ponadto asystentem krajowym Świeckiego Instytutu Caritas Christi. Jest autorem kilkudziesięciu prac z zakresu historii polskich dominikanów, głównie w średniowieczu. Zob.: S. Gołąb, Nasz nowy przeor, „Dominik nad Dolinką. Pismo parafii św. Dominika w Warszawie”, (2004) nr 46, s. 4-5.

${ }^{216}$ APPD, sygn. Kn 43, Korespondencja archiwisty z lat 2001-2004: J.A. Spież, Sprawozdanie z działalności Archiwum Polskiej Prowincji Dominikanów od 13 III 2000 do 27 X 2001, s. 1.

${ }^{217}$ Tamże, s. 3.

${ }^{218}$ Tamże, s. 1.

${ }^{219}$ Tamże, s. 1; APPD, sygn. Kn 43, Korespondencja archiwisty z lat 2001-2004: J.A. Spież, Sprawozdanie z działalności Archiwum Polskiej Prowincji Dominikanów za rok 2002, s. 1.

${ }^{220}$ APPD, sygn. Kn 44, Korespondencja archiwisty z lat 2005-2008: J.A. Spież, Sprawozdanie z działalności Archiwum Polskiej Prowincji Dominikanów za rok 2004, k. nlb. 
Od 3 stycznia 2009 r. oficjum archiwisty prowincji pełni Ireneusz Wysokiński $^{221}$. W tym samym roku, po dłuższych staraniach, archiwum przyznano dawny gabinet biblioteczny, który dwa lata później został gruntownie wyremontowany i zaadoptowany na nowe lektorium ${ }^{222}$. Na potrzeby przechowywania materiałów archiwalnych pozyskano także regały stojące pośrodku bibliotecznych magazynów starodruków. W ostatnich latach uzupełniono katalog rękopisów bibliotecznych o kilkadziesiąt nowych pozycji oraz opracowano spisy schematyzmów, dyrektoriów, kalendarzy liturgicznych i mikrofilmów. Systematyzacji poddano także kartotekę biograficzną dominikanów polskich ${ }^{223}$. W 2013 r. ukazały się drukiem inwentarz archiwum klasztoru w Gidlach, opracowany przez Aleksandra Litew$\mathrm{kę}^{224}$ oraz pierwsza część katalogu rękopisów bibliotecznych (obejmująca 400 jednostek), przygotowana przez Annę Markiewicz ${ }^{225}$. Na dużą skalę zapoczątkowany został proces digitalizacji jednostek i pomocy archiwalnych, z których większość udostępniono w Dominikańskiej Bibliotece Cyfrowej „Armarium”. Wielkim wyzwaniem stało się zwalczenie szkodliwej działalności owadów - od czerwca do października 2012 r. doszło do kompleksowej dezynsekcji magazynu archiwum ekologiczną metodą anoksji (czyli bez użycia tlenu) ${ }^{226}$. Setki rękopisów i fotografii znalazło się także w bezkwasowych pudłach ochronnych. Kontynuowane są prace konserwatorskie i zabezpieczające - w 2013 r. konserwacji poddano 314 rękopisów muzykaliów gidelskich, a w 2014 r. wybrane kodeksy średniowieczne i 86 krakowskich dyplomów pergaminowych ${ }^{227}$. Ostatnie z przedsięwzięć nie byłoby możliwe bez dofinansowania ze strony Ministerstwa Kultury i Dziedzictwa Narodowego.

${ }^{221}$ APPD, bez sygn., I. Wysokiński, Sprawozdanie z działalności Archiwum Polskiej Prowincji Dominikanów od 3 stycznia 2009 roku, s. 1. Ireneusz Wysokiński (ur. 1958) wstąpił do Zakonu Kaznodziejskiego w 1986 r., a święcenia kapłańskie przyjął w 1993 r. Studiował w Warszawie, Lublinie i Krakowie; doktorat z historii uzyskał w 2004 r. Przed wstąpieniem do zakonu, pracował w Oddziale Zbiorów Specjalnych Biblioteki Uniwersyteckiej UW (1983-1984) i w Archiwum Akt Dawnych w Warszawie (1984-1986). Po przyjęciu święceń kapłańskich przebywał na Węgrzech (1993-2008), gdzie był m.in. kapelanem uniwersyteckim i wykładowcą na Uniwersytecie w Debreczynie oraz współpracownikiem Ośrodka Historycznego Węgierskiego Wikariatu Dominikanów w Vasvár. Po powrocie do Krakowa został archiwistą prowincji (2009) i wykładowcą w Kolegium Dominikanów (od 2011). Jest autorem licznych artykułów i biogramów z zakresu historii polskich i węgierskich dominikanów w późnym średniowieczu i okresie nowożytnym. Dziękuję o. dr. Ireneuszowi Wysokińskiemu OP za udzielenie powyższych informacji.

${ }^{222}$ APPD, bez sygn., I. Wysokiński, Sprawozdanie z działalności archiwisty Prowincji za okres 25 marca 2010 - 20 października 2013, s. 7.

${ }^{223}$ Tamże, s. 2-3.

${ }^{224}$ Litewka, Inwentarz zespotu, s. 111-191.

${ }^{225}$ Katalog rękopisów bibliotecznych ze zbiorów Archiwum Polskiej Prowincji Dominikanów w Krakowie, cz. 1, oprac. A. Markiewicz, Kraków 2013 (Studia i Źródła Dominikańskiego Instytutu Historycznego w Krakowie, t. 12).

${ }^{226}$ APPD, bez sygn., I. Wysokiński, Sprawozdanie z działalności archiwisty Prowincji za okres 25 marca 2010 - 20 października 2013, s. 5.

${ }^{227}$ Tamże; APPD, bez sygn., I. Wysokiński, Sprawozdanie z działalności archiwisty prowincji za okres od 1 stycznia 2014 do 30 września 2017, s. 5. 
Prace $\mathrm{w}$ archiwum skupiają się obecnie na inwentaryzacji spuścizn braci oraz ponownym uporządkowaniu i opracowaniu akt klasztornych i prowincjalnych (prowincji ruskiej, galicyjskiej oraz polskiej). W 2018 r. archiwum jako jedno z pierwszych instytucji kościelnych w Polsce rozpoczęło wdrażanie Zintegrowanego Systemu Informacji Archiwalnej (ZoSIA). Opisy jednostek - otrzymujących nowe sygnatury liczbowe - zostaną w przyszłości udostępnione w serwisie https://www.szukajwarchiwach.gov.pl.

\section{Podsumowanie}

Długie, a niekiedy pełne zawirowań dzieje centralnego archiwum dominikanów w Krakowie stanowią ważny element historii polskiej prowincji zakonu. Jego losy ściśle łączą się z przeszłością najstarszego konwentu braci kaznodziejów na ziemiach polskich, a także jego archiwum i biblioteki. Idea stworzenia archiwum całej prowincji, do którego trafiać miały kopiariusze i dokumenty dotyczące wszystkich klasztorów wchodzących w jej skład, znalazła odzwierciedlenie w prawodawstwie dominikańskim w okresie nowożytnym. W tym czasie kapituły generalne nakazywały zakonnikom także odpowiednie przechowywanie przywilejów, bulli i akt procesów oraz spisywanie źródeł historycznych. W XVIII stuleciu archiwum prowincji polskiej znajdowało się w bibliotece klasztoru w Krakowie. Plany beatyfikacji Męczenników Sandomierskich sprawiły, że generał zakonu polecił inwentaryzowanie jego zbiorów. W pierwszej połowie XIX w. archiwalia przechowywano już w osobnym pomieszczeniu, dzięki czemu nie zostały zniszczone w czasie pożaru klasztoru w $1850 \mathrm{r}$. Wkrótce potem historyczne dokumenty powróciły jednak do biblioteki konwentu, gdzie prawdopodobnie znajdowały się do $1937 \mathrm{r}$. W pierwszej połowie XX w. wśród polskich dominikanów zaczęła wzrastać świadomość znaczenia źródeł archiwalnych. Podjęto wówczas bardziej aktywne działania mające na celu ich ochronę, zabezpieczenie i uporządkowanie. Choć urząd archiwariusza prowincji ustanowiono jeszcze w 1926 r., Archiwum Polskiej Prowincji Dominikanów w Krakowie w obecnym kształcie zaczęto organizować ponad dwie dekady później. Po II wojnie światowej zainicjowano prace inwentaryzacyjne na szeroką skalę oraz w znacznie większym stopniu umożliwiono prowadzenie badań naukowcom spoza zakonu.

Zasób archiwum stanowi bezcenne dziedzictwo, ale także zobowiązanie na przyszłość. Obok tradycyjnych wyzwań stojących obecnie przed dominikanami i pracownikami świeckimi - takich jak konserwacja zbiorów i rozwiązanie problemów lokalowych - pojawiły się nowe, będące znakami czasu. Można do nich zaliczyć bezpieczne przechowywanie plików cyfrowych, umieszczenie opisów archiwalnych w systemie ZoSIA czy udostępnianie katalogów w Internecie. Ponieważ artykuł stanowi tylko zarys dziejów archiwum prowincji, w przyszłości konieczne będą także dalsze badania z zakresu archiwistyki dominikańskiej. Ich tematem mogłoby stać się kształtowanie zasobu instytucji, jak również historia i metodyka pracy poszczególnych kancelarii prowincjalnych oraz archiwów klasztornych, których akta ostatecznie trafiły do archiwum centralnego w Krakowie. 


\section{BIBLIOGRAFIA}

\section{Źródła}

\section{Archiwum Opactwa Cystersów w Mogile}

sygn. 595, Diarium itineris provincialis a die $27^{\mathrm{ma}}$ Octobris anni 1806 (fotokopia w APPD).

\section{Archiwum Państwowe w Poznaniu}

sygn. 5663/0/-/219, Informatory o materiałach archiwalnych innych instytucji: Dominikaner Kloster in Krakau, Urkunden Nr 1-110.

\section{Archiwum Polskiej Prowincji Dominikanów w Krakowie (APPD)}

bez sygn., [R. Świętochowski, Fragment wystąpienia na temat Archiwum Polskiej Prowincji Dominikanów i znajdujących się w nim źródeł do historii nowożytnej polskich dominikanów].

bez sygn., [R. Świętochowski], Archiwum OO. Dominikanów w Krakowie [mps, wersja nr 1].

bez sygn., [R. Świętochowski], Archiwum OO. Dominikanów w Krakowie [mps, wersja $\mathrm{nr} 2]$.

bez sygn., Adam Studziński OP, Sprawa rocznicy 750-lecia zakonu dominikańskiego w Polsce.

bez sygn., I. Wysokiński, Sprawozdanie z działalności archiwisty Prowincji za okres 25 marca 2010 - 20 października 2013.

bez sygn., I. Wysokiński, Sprawozdanie z działalności archiwisty Prowincji za okres 25 marca 2010 - 20 października 2013.

bez sygn., I. Wysokiński, Sprawozdanie z działalności archiwisty prowincji za okres od 1 stycznia 2014 do 30 września 2017.

bez sygn., I. Wysokiński, Sprawozdanie z działalności Archiwum Polskiej Prowincji Dominikanów od 3 stycznia 2009 roku.

bez sygn., K. Zawadzka, Problem rekonstrukcji biblioteki klasztoru Dominikanów w Krakowie.

bez sygn., Statut Polskiej Prowincji Zakonu Kaznodziejskiego, Warszawa 1983.

bez sygn., Statut Polskiej Prowincji Zakonu Kaznodziejskiego, Warszawa 1986.

sygn. Kn 1, Protokół czynności Archiwum Prowincji Polskiej OO. Dominikanów w Krakowie za Prowincjalstwa Przew. O. Dra Bernarda Przybylskiego, tom I.

sygn. Kn 2, Projekt inwestycji renowacyjnych w Archiwum OO. Dominikanów w Krakowie, [ul.] Stolarska 12, $1970 \mathrm{r}$.

sygn. Kn 17, Korespondencja archiwisty z lat 1868-1956.

sygn. Kn 19, Korespondencja archiwisty z lat 1957-1962.

sygn. Kn 20, Korespondencja archiwisty z lat 1963-1965.

sygn. Kn 21, Korespondencja archiwisty z lat 1966-1968

sygn. Kn 22, Korespondencja archiwisty z lat 1969-1971.

sygn. Kn 23, Korespondencja archiwisty z lat 1972-1973.

sygn. Kn 24, Korespondencja archiwisty z lat 1973-1977.

sygn. Kn 43, Korespondencja archiwisty z lat 2001-2004.

sygn. Kn 44, Korespondencja archiwisty z lat 2005-2008.

sygn. Kn 45, Spis i streszczenie dyplomów pergam[inowych]. Spis antyfonarzy [spisy, regesty i odpisy dokumentów przechowywanych w archiwum i bibliotece klasztoru Dominikanów w Krakowie, sporządzone przez br. Kazimierza Jucewicza]. 
sygn. Kn 46, Regesty 531 pergaminów OO. Dominikanów krakowskich z lat 1227 - 1894 zinwentaryzowanych przez dyrektora Archiwum Państwowego w Poznaniu dra Kazimierza Kaczmarczyka od września 1943 do sierpnia 1944.

sygn. Kr 3, Protocollum Priuilegiorum, Fundationum, Dotationum, Inscriptionum, Censuum, Prouentuum, Villarum, Domorum, Obligationum, Literarum, Regalium, Commisionum... Concordiarum, Inuentarium, Clenodiorum, Apparamentorum, Librorum Choralium, Ecclesiae, et Conuentus SS. Trinitatis Fratrum Praedicatorum fideliter descriptum, et consignatum Per Fr. Arnolfum Presinium Magistrum. 1648.

sygn. Kr 4, Protocollon Privilegiorum, Fundationum, Donationum, Inscriptionum, Censuum, Prouentuum, Villarum, Domorum, Obligationum, Literarum Regalium, Commisionum, Decretorum, Transactionum, Concordiarum, Inventariorum, ex Antiquiori Protocollo per olim R. A. P. M. F. Arnolphum Presinium in Anno 1648 - mo Conscripto postea sub Prioratu A - m R - di et Eximii Patris S. Th. Magistri P. Casimiri Napolski in secundissimo quia secundo ipsius Triennio, de Verbum relictis adhuc aliquibus descriptionibus, utpote in aliud Volumen Seorsum per modum Continuationis Una cum nonnullis accessoriis Bonorum, Fundationum Nouarum, Obligationum, Ornamentorum Ecclesiae reducandis, et inscribendis per P. F. Anselmum Dorecki Agentem protunc Causalem Conventus adiuvante Clerico fideliter Transcriptum et Consignatum Anno a Descriptione Nativitatis Christi Domini M. DCC.

sygn. $\operatorname{Kr} 5$, Descriptio fundationis Ecclesiae S[anctissi]mae Trini[ta]tis et Mona[ste]rii Sacri Ordinis Fr[atr]um Praed[icatoru]m Villarum Prouentuu[m], \& Censuum Con[ven] tus Cracouiensis. Aliorumq[ue] Bonorum Immobilium \&c. Per Fr[atr]em Arnolphum S: T: M[a]g[ist]rum. Descriptio Obligationum Missarum Anniuersariorum et Oratio$\mathrm{nu}[\mathrm{m}]$. Ex Antiquis Scriptu[ri]s. Adnotationib[us]q[ue]. in Annalibus, ex Calendis Pargameneis. Copiis Intercisarum et Recognitionum et ex Authenticis Actis Consiliorum Con[ven]tus Cracoui[ensi]s. Informatio de structura Altaris Maioris. De Organis. Descriptio Gradualium, Antiphonariorum, Psalteriorum, Processionalium, Aliorumq[ue]. Librorum choralium. Inwentarz Zakristyi.

sygn. Kr 6, Księga zawierająca dokumenty i materiały do historii kościoła i klasztoru OO. Dominikanów krakowskich od 1219-1749 r.

sygn. Kr 12, Incipit Liber Quartus Consiliorum Patrum in Conventu Cracoviensi Sanctissimae Trinitatis Ordinis Praedicatorum Anno Domini 1772 Die 16 Novembris. Triennium Prioratus peragente Adm. Rndo ac Eximio Patre Sacrae Theologiae Magistro Exprovinciali Patre Basilio Barski [et aliorum].

sygn. $\mathrm{Kr} 23$, Liber continens in se tenores, sive transsumpta omnium litterarum, privilegiorumque apostolicarum necnon Regalium aliorumque tam spiritualium, quam secularium, necnon Obligationum et Proventuum Conventus Cracoviensis Sanctissimae Trinitatis ordinis predicatorum extractus ex litteris originalibus prout in forma habentur de verbo ad verbum cura non mediocri R. patre fratre Hieronimo de Brzezek sacre theologie lectore ac Conventus iam dicti priore necnon totius provincie Polonie Vicario generali procurante M. D. XXXI. Salutis nostre Anno; APPD, sygn. Kr 1, Liber antiquitatum et intercisarum, bullar[um] sum. Pontif. ac privilegiorum regalium et censuum inscriptionu[m] atq[ue] Obligationu[m] Missarum. Con[ven]tus Ord[in] is Praed[icatoru]m SS-mae Trini[ta]tis.

sygn. Kr 41, Inwentarz Kościoła Zakonnego i Klasztoru Xięży Dominikanów w Gminie I-szej przy ulicy Szeroka zwanej w Wolnym Mieście Krakowie sytuowanego na mocy tak Rozporządzenia Wydziału Spraw Wewnętrznych w Senacie Rządzącym dnia 20 Mca Paźdr. Roku 1820, jako też Odezwy Konsystorza Jeneralnego Krakowskiego pod dniem. Mca. Roku tegoż 182 . Nr uczynionych stosownie do Instrukcji w tey mie- 
rze wydaney przez Delegowanych Kommisarzy Cywilno Duchownych sporządzony.

Opis czyli Inwentarz Kościoła S. Idziego.

sygn. $\mathrm{Kr}$ 43, Inwentarz Kościoła i klasztoru OO. Dominikanów tudzież Kościoła św.

Idziego w Krakowie (w r. 1875) spisany w roku 1874 wg instrukcji Namiestnictwa

Wysokiego c. k. Namiestnictwa z dn. 6 lutego 1870 liczba 2070.

sygn. Kr 405, Inwentarz obrazów w Konwencie Św. Trójcy. Kraków I. 1944.

sygn. Kr 791, Liber Consiliorum Conventus Cracoviensis FF. Ord. Praedicatorum A. 1888.

sygn. Kr 842, Kronika Klasztoru krakowskiego OO. Dominikanów przy kościele św. Trójcy od r. 1926.

sygn. Kr 907, K. Jucewicz, Okruszyny biograficzne o niektórych znakomitych Ojcach

Z. Kazn. prowincji polskiej i spis prowincjałów od r. 1609 do 1864 r. jako też i OO.

Przeorów krakowskich.

sygn. Kr 1037/2, Rachunki i kwity klasztoru OO. Dominikanów w Krakowie, 1658-1946. sygn. Kr 1397, Kronika Konwentu OO. Dominikanów w Krakowie z lat 1975-1986.

sygn. Pp 3a/3, Archivum Provinciae Ordinis Authentica Sub numero \& Alphabeto A. D.

1766 Revisum. Archivum Conventuum Copiatim In Bibliotheca Conventus Cracoviensis observatum. Archivum Domus Conventui SS. Trinitatis Conscriptum et Regestratum Anno Domini 1766.

sygn. Pp 3a/4, Archivum Domus Conventui SS. Trinitatis Conscriptum et Regestratum Anno Domini 1766.

sygn. Pp 3a/7, Spis Książek i Akt do Urzędu prowincyała X.X. Dominikanów należących [z 27 IV 1864 r.].

sygn. Pp 36/3, Statutum Provinciae Poloniae Ordinis Praedicatorum, Cracoviae 1970.

sygn. Pp 44, Liber Encyclicarum Provinciae Poloniae Sacrae Ordinis Praedicatorum Sub

Provincialatu Admodum Reverendis ac Eximii Patris Sacrae Theologiae Magistri Pa-

tris Basilii Barski Filij Conventus Cracoviensis Electi in Capitulo Posnaniensi Anno

Domini 1765 Die 14 Septembris Sub Prioratu Admodum Reverendis ac Eximii Patris

Sacrae Theologiae Magistri Patris Michaelis Barwiński Suppriore pro tunc existente

Reverendi Admodum Patris Sacrae Theologiae Lectoris Patris Ludovico Kochmański

Depositario Conventus [Cracoviensis] Inchoatus.

sygn. R. 560, Historia o św. Dominiku i zakonie Jego (cz. 1).

sygn. R. 784, Sadok Barącz, Materyały do napisania Monografii Krajowych.

sygn. S 1/1, Dokumenty osobiste O. Pawła Kielara ur. 30.10.1912 r. w Krościenku Wyżnym, $† 2.1 .1972$ r. w Krakowie.

sygn. S 1/6, Memoriał do Konsilium Prowincji w sprawie bibliotek oraz uwagi o archiwum i kancelarii prowincjalskiej.

sygn. S 3/5, Materiały dotyczące działalności O. Michała Czartoryskiego.

sygn. S 44/8a-b, Acta Capitulorum Provinciae Poloniae Ordinis Praedicatorum, t. 2:

a. 1603-1700, oprac. R.F. Madura.

sygn. S 44/9a, Acta Capitulorum Provinciae Poloniae [Ordinis Praedicatorum], t. 3: a. 1701-1798, oprac. R.F. Madura.

sygn. S 44/9c, Acta Capitulorum Provinciae Poloniae [Ordinis Praedicatorum], t. 3: a. 1701-1798, oprac. R.F. Madura. Supplementum ex registris actorum regiminis rev. morum magistrorum generalium et procuratorum generalium O.P. (a. 1700-1800).

sygn. S 44/10a-b, Acta Capitulorum Provinciae Poloniae Ordinis Praedicatorum, t. 4: ab anno 1801-1863 et ab anno 1920-1978, oprac. R.F. Madura.

sygn. S 44/11b, Acta Capitulorum Provinciae Russiae [Ordinis Praedicatorum], t. 5: ab a. 1598-1772, oprac. R.F. Madura. 
sygn. S 44/12b, Acta Capitulorum: 3. Provinciae Galiciae Orientalis (Galiciae et Lodomeriae) ab anno 1780 ad a. 1916, t. 6, oprac. R.F. Madura.

\section{Biblioteka Kolegium Filozoficzno-Teologicznego Polskiej Prowincji Dominikanów w Krakowie (BDKr)}

bez sygn., Projekt uchwał dla Konsilium Prowincji w dniu 18.2.1959 r. w sprawie archiwum i bibliotek prowincji.

\section{Źródła drukowane}

\section{Prasa}

[List do redakcji „Ami de la Religion”], „Czas” (1850) nr 184, s. 1.

Góra Jan, Ostatniemu Prusowi, „Tygodnik Powszechny”, (1979) nr 16, s. 4.

Szpor Romuald, Biblioteka i archiwum świadkami życia wspólnoty dominikańskiej, „Życie i Myśl”, (1977) nr 10, s. 45-56.

\section{Wydawnictwa zwarte}

Acta Capitulorum Generalium Ordinis Praedicatorum, t. 5: ab anno 1558 usque ad annum 1600, Romae 1901 (Monumenta Ordinis Fratrum Praedicatorum Historica, t. 10).

Acta Capitulorum Generalium Ordinis Praedicatorum, t. 6: ab anno 1601 usque ad annum 1628, Romae 1902 (Monumenta Ordinis Fratrum Praedicatorum Historica, t. 11).

Acta Capitulorum Generalium Ordinis Praedicatorum, t. 7: ab anno 1629 usque ad annum 1656, Romae 1902 (Monumenta Ordinis Fratrum Praedicatorum Historica, t. 12).

Acta Capitulorum Generalium Ordinis Praedicatorum, t. 9: ab anno 1725 usque ad annum 1844, Romae 1904 (Monumenta Ordinis Fratrum Praedicatorum Historica, t. 14).

Bzovii Abraham, Propago D[ivi] Hyacinthi thaumaturgi Poloni, seu De rebus praeclare gestis in Prouincia poloniae Ordinis Praedicatorum commentarius, Venetiis 1606.

Fontana Vincentio Maria, Constitutiones, declarationes et ordinationes capitulorum generalium S. Ordinis Praedic. ab anno 1220 usque ad 1651 emanatae, Romae 1655.

Fontana Vincentio, Lo-Cicero Cajetano, Constitutiones, declarationes et ordinationes capitulorum generalium Sacri Ordinis Fratrum Praedicatorum ab anno 1220 ad 1650 emanatae [...] usque ad annum 1862 continuatae [...], cz. 1, Romae 1862.

Grabowski Ambroży, Wspomnienia, t. 2, Kraków 1909 (Biblioteka Krakowska, z. 41).

Kalinka Walerian, Historya pożaru miasta Krakowa, Kraków 1850.

Księga konstytucji i zarzadzeń Braci Zakonu Kaznodziejów, Poznań 2003.

Nowowieyski Felician, Phaenix decoris et ornamenti Provinciae Poloniae S. Ordinis Praedicatorum D. Hyacinthus Odrovansius redidivus..., Posnaniae 1752.

Sieykowski Michał, Świątnica Pańska to iest Kościoł Boga w Troycy SS. iedynego z klasztorem WW. OO. Dominikanow w Krakowie, znacznemi świętych Pańskich relikwiami, kaplicami, ottarzami, obrazami [...] przyozdobiona, wielkich $w$ cnote [...] licznych mężow maiaca, Kraków 1743.

Zbiór formut Zakonu Dominikańskiego Prowincji Polskiej 1338-1411 = (Dictamina litterarum O. P. Provinciae Polonae), przedłożył do druku J. Woroniecki, poprzedził wstępem i wydał J. Fijałek, Kraków 1938 (Archiwum Komisji Historycznej, t. 12, cz. 2).

\section{Opracowania}

m, [Bibljoteki klasztorne w Krakowie], „Przegląd Biblijograficzno-Archeologiczny”, 1 (1881) s. 110-111. 
Abraham Władysław, Sprawozdanie z poszukiwań w archiwach i bibljotekach rzymskich do dziejów Polski w wiekach średnich za lata 1899-1913, w: Archiwum Komisji Historycznej, serja 2, t. 1, Kraków 1923 (Wydawnictwa Komisji Historycznej Polskiej Akademji Umiejętności, serja 2, nr 78), s. 1-188.

Barącz Sadok, Klasztór i kościót Dominikanów w Krakowie, Poznań 1888.

Brzozecki Sławomir, Historiografia dominikańska w czasach nowożytnych (XVII-XIX w.), „Kościół w Polsce. Dzieje i kultura”, 6 (2007) s. 15-24.

Dudík Beda, Archive im Königreiche Galizien und Lodomerien. Im Auftrage des hohen Staatsministeriums beschrieben und durchforscht, Wien 1868 (Archiv für österreichische Geschichte, t. 39).

Fijałek Jan, Wstęp, w: Zbiór formuł Zakonu Dominikańskiego Prowincji Polskiej 13381411 = (Dictamina litterarum O. P. Provinciae Polonae), przedłożył do druku J. Woroniecki, poprzedził wstępem i wydał J. Fijałek, Kraków 1938 (Archiwum Komisji Historycznej, t. 12, cz. 2), s. 219-256.

Gałuszka Tomasz, Świętochowski (Świętochowski-Sapek) Walery, w: Polski słownik biograficzny, t. 51, red. A. Romanowski, Warszawa-Kraków 2016-2017, s. 513-514.

Gałuszka Tomasz, W przededniu powstania Studium Generale. Nowe badania nad czternastowiecznym zachowanym księgozbiorem dominikanów krakowskich, „Przegląd Tomistyczny", 16 (2010) s. 25-42.

Gołąb Stanisław, Nasz nowy przeor, „Dominik nad Dolinką. Pismo parafii św. Dominika w Warszawie", (2004) nr 46, s. 4-5.

Grünhagen Colmar, Bericht über eine archivalische Reise nach Krakau (Pfingsten 1868), ,Zeitschrift des Vereins für Geschichte (und Alterthum) Schlesiens”, 9 (1868) s. $129-143$.

Habuda Małgorzata, Płaszczyńska-Herman Katarzyna, Kaczmarek Janusz, Biblioteka Kolegium Filozoficzno-Teologicznego oo. Dominikanów w Krakowie, „Tytuł Ujednolicony. Wokół katalogu centralnego NUKAT", (2013) nr 11, s. 3-7.

Kalinowska Katarzyna, Jacek Woroniecki o społeczeństwie i państwie, Lublin 2005.

Kamiński Adam, Zarys dziejów Archiwum Państwowego w Krakowie (1792) 1878-1952, Kraków 2012 (Biblioteka Krakowska, nr 156).

Katalog mikrofilmów muzycznych, II, oprac. M. Prokopowicz, Warszawa 1962 (Biblioteka Narodowa, Katalog mikrofilmów, nr 9).

Katalog rękopisów bibliotecznych ze zbiorów Archiwum Polskiej Prowincji Dominikanów w Krakowie, cz. 1, oprac. A. Markiewicz, Kraków 2013 (Studia i Źródła Dominikańskiego Instytutu Historycznego w Krakowie, t. 12).

Katalog zabytków sztuki w Polsce, t. 4: Miasto Kraków, cz. 3: Kościoły i klasztory Śródmieścia, 2. [1] Tekst, red. A. Bochnak, J. Samek, Warszawa 1978.

Kosiński Józef Adam, Doskonały książkołap. Wizyta Tadeusza Czackiego w bibliotece dominikanów krakowskich, „Roczniki Biblioteczne”, (1960) nr 1/2, s. 223-229.

Kuźmina Dariusz, Habuda Małgorzata, Biblioteka oo. Dominikanów w Krakowie, w: Kraków-Lwów. Książki, czasopisma, biblioteki XIX i XX wieku, t. 10, red. H. Kosętka, G. Wrona, G. Nieć, Kraków 2011, s. 389-399.

Litewka Aleksander, Inwentarz zespołu akt Gidle. Klasztor ojców dominikanów z lat (1479) 1615-1998, „Archiwa, Biblioteki i Muzea Kościelne”, 99 (2013) s. 111-191.

Madura Roman Fabian, Polonika w Archiwum Głównym Zakonu OO. Dominikanów w Rzymie, „Archiwa, Biblioteki i Muzea Kościelne”, 37 (1978) s. 297-307.

Matwijów Maciej, Walka o lwowskie dobra kultury w latach 1945-1948, Wrocław 1996.

Mazur Zygmunt, Dominikanie we Lwowie (1939-1946), ,Tygodnik Powszechny”, (1990) nr 38, s. 4-5. 
Mazur Zygmunt, Gąsiorowski Stefan, Inwentarz archiwum klasztoru Dominikanów w Żółkwi, APPD, w: J.T. Petrus, Kościoły i klasztory w Żółkwi, Kraków 1994 (Materiały do dziejów sztuki sakralnej na ziemiach wschodnich dawnej Rzeczypospolitej, cz. 1: Kościoły i klasztory rzymskokatolickie dawnego województwa ruskiego, t. 2), s. $155-163$.

Mazur Zygmunt, Gliński Efrem Kazimierz Felicjan, w: Słownik polskich teologów katolickich:, t. 5, red. L. Grzebień, Warszawa 1983, s. 447-449.

Mazur Zygmunt, Gmurowski Andrzej Florian, w: Słownik polskich teologów katolickich:, t. 5, red. L. Grzebień, Warszawa 1983, s. 454-456.

Mazur Zygmunt, Kielar Paweł Władysław, w: Słownik polskich teologów katolickich, t. 6, red. L. Grzebień, Warszawa 1983, s. 64-67.

Mazur Zygmunt, Ogarek Zygmunt Julian Jan, w: Słownik polskich teologów katolickich, t. 6, red. L. Grzebień, Warszawa 1983, s. 577-578.

Mazur Zygmunt, Słowo wstęne, w: K. Mrowiec, Katalog muzykaliów gidelskich. Rękopisy muzyczne kapeli klasztoru gidelskiego przechowywane w Archiwum Prowincji Polskiej OO. Dominikanów w Krakowie, Kraków 1986, s. 5-6.

Mazur Zygmunt, Świętochowski-Sapek Robert Walery, w: Słownik polskich teologów katolickich, t. 7, red. L. Grzebień, Warszawa 1983, s. 297-302.

Miławicki Marek, Dominikański gazda na Wiktorówkach. O. Pawet Kielar i duszpasterstwo tatrzańskie w latach 1958-1967, w: Komunistyczny aparat represji wobec Polskiej Prowincji Dominikanów, red. M. Miławicki, M. Wenklar, Kraków 2015 (Kościół w okowach), s. 330-396.

Mrowiec Karol, Katalog muzykaliów gidelskich. Rękopisy muzyczne kapeli klasztoru gidelskiego przechowywane w Archiwum Prowincji Polskiej OO. Dominikanów w Krakowie, Kraków 1986.

Müller Wiesław, Kopiariusze konwentów dominikańskich w Archiwum OO. Dominikanów w Krakowie [komunikat], „Sprawozdania z Czynności Wydawniczej i Posiedzeń Naukowych oraz Kronika Towarzystwa Naukowego Katolickiego Uniwersytetu Lubelskiego", (1961) nr 11, s. 98-101.

Pietrzkiewicz Iwona, Biblioteki mendykantów krakowskich w okresie średniowiecza - stan i perspektywy badań, w: Mendykanci w średniowiecznym Krakowie, red. K. Ożóg, T. Gałuszka, A. Zajchowska, Kraków 2008 (Studia i Źródła Dominikańskiego Instytutu Historycznego w Krakowie, t. 4), s. 133-147.

Puciłowski Józef, Portrety imienne i bezimienne. Polscy dominikanie a bezpieka 19451989, Kraków 2017.

Spież Jan Andrzej, Madura Fabian Roman, w: Stownik polskich teologów katolickich, t. 8, red. J. Mandziuk, Warszawa 1995, s. 356-357.

Szczygieł Florian, Informacje o zbiorze materiałów archiwalnych o. Jacka Woronieckiego $O P$, ,Roczniki Teologiczno-Kanoniczne”, 6 (1959) z. 1-2, s. 89-98.

Szymborski Wiktor, Krakowscy dominikanie i ich wkład w rozwój historiografii polskiej, w: Krakowskie środowisko historyczne XV-XX w. Ludzie - idee - dzieła, red. T. Gąsowski, J. Smołucha, Kraków 2018, s. 305-338.

Szymborski Wiktor, Ze Lwowa poprzez Włochy, Austrię do odrodzonej Polski-sylwetka i dorobek naukowy O. Romana Fabiana Madury, „Res Gestae”, 4 (2017) s. 96-121.

Świętochowski Robert, Biblioteka oo. Dominikanów w Krakowie, „Archiwa, Biblioteki i Muzea Kościelne”, 33 (1976) s. 299-311.

Świętochowski Robert, Chruszczewski Adam, Polonia Dominicana apud extraneos, w: Studia nad historia dominikanów w Polsce 1222-1972, t. 2, red. J. Kłoczowski, Warszawa 1975, s. 467-572. 
Świętochowski Robert, Nowowiejski Felicjan, w: Polski słownik biograficzny, t. 23, red. E. Rostworowski, Wrocław 1978, s. 401.

Świętochowski Robert, Ogarek Julian Jan Zygmunt, w: Polski słownik biograficzny, t. 23, red. E. Rostworowski, Wrocław 1978, s. 588-589.

Świętochowski Robert, Źródła do dziejów nowożytnych Zakonu Kaznodziejskiego w Polsce, ,Sprawozdania Towarzystwa Naukowego Katolickiego Uniwersytetu Lubelskiego" (1970) nr 19, s. 84-91.

Wichrowicz Cyprian Jan, Mazur Bruno Zygmunt, w: Słownik polskich teologów katolickich, t. 9, red. J. Mandziuk, Warszawa 2006, s. 405-406.

Włodek Zofia, Inventaire des manuscrits médiévaux latins, philosophiques et théologiques de la Bibliothèque des Pères Dominicains de Cracovie, „Mediaevalia Philosophica Polonorum", 14 (1970) s. 155-186.

Woroniecki Jacek, Gmurowski Andrzej Florian, w: Polski słownik biograficzny, t. 8, red. W. Konopczyński, Wrocław 1959-1960, s. 137.

Wysokiński Ireneusz, Kraków - Archiwum Polskiej Prowincji Dominikanów, w: Rękopisy w zbiorach kościelnych, oprac. T. Makowski, Warszawa 2014, s. 112-115.

Zawadzka Krystyna, Ze źródet $i$ stanu badań dotyczacych dawnych klasztornych bibliotek dominikanów w polskich prowincjach, „Nasza Przeszłość”, 39 (1973) s. 213-228.

Zdanek Maciej, Szkoły i studia dominikanów krakowskich w średniowieczu, Warszawa 2005.

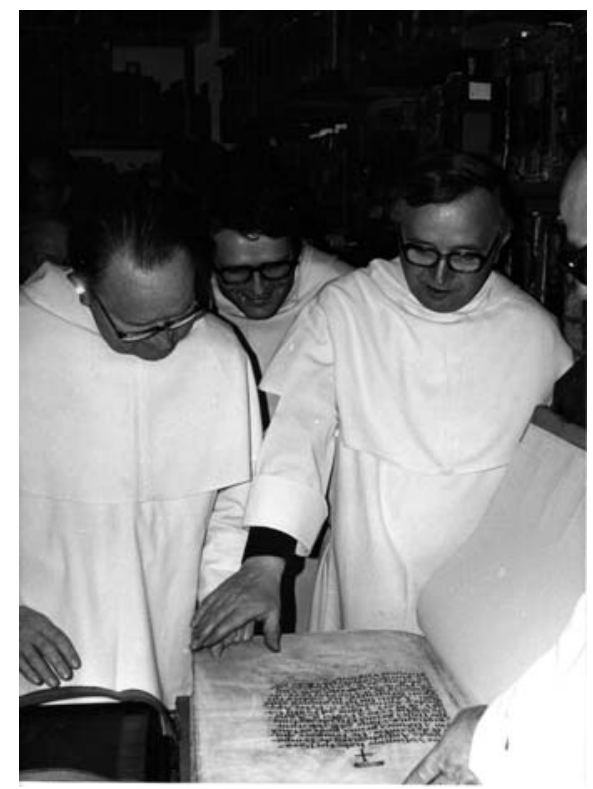

I1.1. Wizyta generała zakonu dominikanów Vincenta de Couesnongle w magazynie głównym

Archiwum Polskiej Prowincji Dominikanów w Krakowie 11 maja 1978 roku.

Od lewej ojcowie: Vincent de Couesnongle, Mateusz Bogucki (?), Zygmunt Bruno Mazur (fot. APPD, bez sygnatury). 


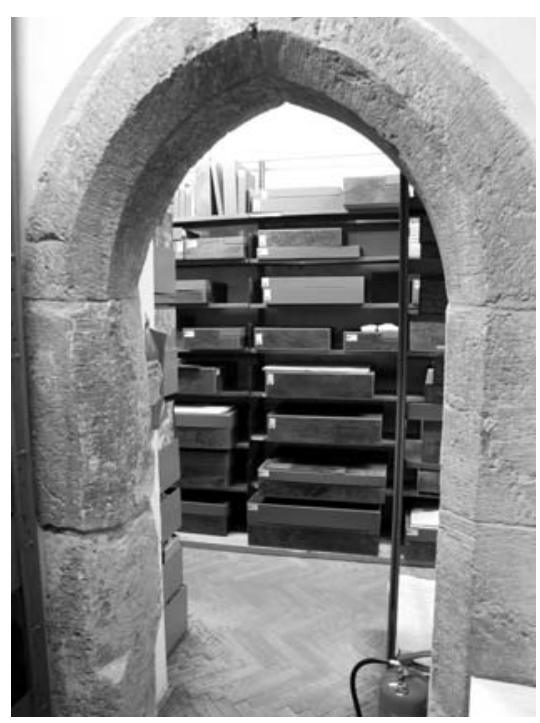

I1.2. Wejście do magazynu liturgików i rękopisów bibliotecznych w Archiwum Polskiej Prowincji Dominikanów w Krakowie.

W głębi widoczne rękopisy liturgiczne

w pudłach ochronnych (fot. autora).

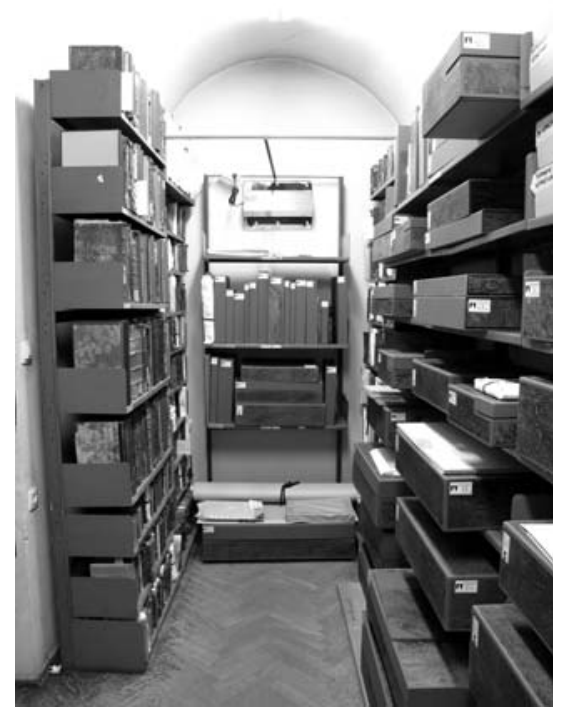

I1.3. Magazyn liturgików i rękopisów bibliotecznych w Archiwum Polskiej Prowincji Dominikanów w Krakowie (fot. autora). 


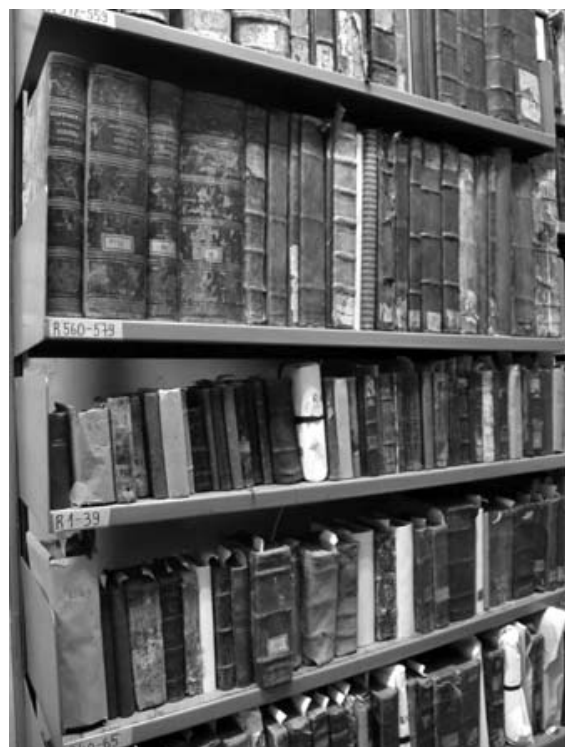

Il.4. Rękopisy biblioteczne w Archiwum Polskiej Prowincj1 Dominikanów w Krakowie (fot. autora).

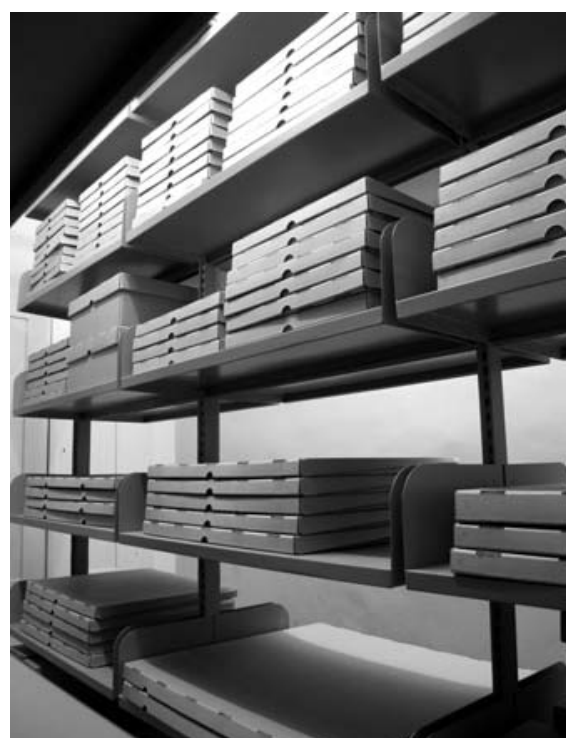

I1.5. Magazyn dyplomów pergammowych w Aremrwumr rorskiej Prowincji Dominikanów w Krakowie (fot. autora). 


\title{
'A CONSIDERABLE TREASURE OF VALUABLE MEMENTOES'. AN OUTLINE OF THE HISTORY OF THE ARCHIVES OF THE POLISH PROVINCE OF DOMINICANS IN KRAKOW
}

\begin{abstract}
Summary
In the Middle Ages, the brothers of the Order of Preachers held archival material in trunks and manuscripts of deceased monks in the conventual libraries. The term 'archivum commune provinciae' ('a common provincial archive') appears for the first time in the records of the general chapter of the Dominicans in Venice in 1592. Subsequent chapters recommended storing privileges, bulls and trial files in a safe way, registering sources for the history of the province, and producing inventories of movables and immovables, whose duplicates were to be held in the central provincial archive. Finally, provincial archives were legally established at the general chapter in Rome in 1756. In the 18th century, the Archives of the Polish Province was held in the library of the Holy Trinity Priory in Krakow. Due to the beatification plans for the Sandomierz martyrs, the Master of the Order gave instructions that this archives should be catalogued. In the first half of the next century, it was held in a separate room, and thanks to that, the archives survived the fire of the priory in 1850 . In the following decades the archives was stored in the library again. At the turn of the 19th and 20th centuries, brother Kazimierz Jucewicz looked after the archives, and in the second decade of the 20th century, father Jacek Woroniecki was responsible for arranging and describing it. In 1926, the post of provincial archivist was established, and it was taken up by the following fathers, one after another: Fabian Madura, Zygmunt Ogarek, Andrzej Gmurowski, Robert Świętochowski and Efrem Gliński. In 1937, the archives was transferred to a separate storehouse. The fact that a large number of materials from the liquidated priories in the South-Eastern Borderlands were placed in Krakow contributed to establishing the Archives of the Polish Province of Dominicans in its present shape in 1947. After that year, the office of the provincial archivist has been held by the following fathers: Robert Świętochowski, Paweł Kielar, Zygmunt Bruno Mazur and Jan Andrzej Spież. Since 2009, father Ireneusz Wysokiński has been in charge of the archives.
\end{abstract}

Key words: Archives of the Polish Province of Dominicans; archives; Dominicans; Polish Province of Dominicans; Dominican Priory in Krakow; Krakow 